\title{
SUBSÍDIOS PARA ADEQUAR A CANAVICULTURA DOS FORNECEDORES DE PIRACICABA À LEGISLAÇÃO AMBIENTAL
}

\author{
MARCOS FARHAT
}

Engenheiro Agrônomo

Orientador: Prof. Dr. MARCOS SILVEIRA BERNARDES

Dissertação apresentada à Escola Superior de Agricultura "Luiz de Queiroz", Universidade de São Paulo, para obtenção do título de Mestre em Agronomia. Área de Concentração: Fitotecnia.

$$
\begin{gathered}
\text { P I R A C I C A B A } \\
\text { Estado de São Paulo - Brasil } \\
\text { Junho }-2005
\end{gathered}
$$




\section{ERRATA}

FARHAT, M. Subsidios para adequar a agricultura dos fornecedores de Piracicaba à legislação ambiental. Piracicaba, 2005. 121 p. Dissertação (Mestrado) - Escola Superior de Agricultura "Luiz de Queiroz", Universidade de São Paulo.

Referente à Tabela 31 - Quadro geral de resultados leia-se:

\begin{tabular}{|c|c|c|c|c|c|c|c|c|c|c|c|c|c|c|c|}
\hline Dados referente somente aos Fornecedores & $\frac{\infty}{\frac{0}{5}}$ & 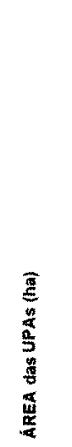 & 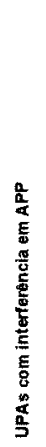 & 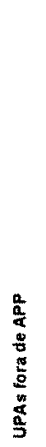 & 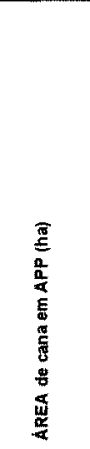 & 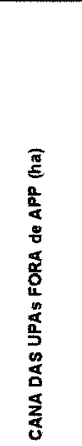 & 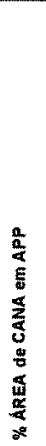 & 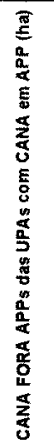 & 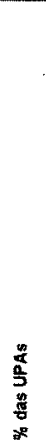 & 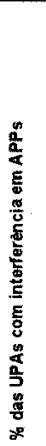 & 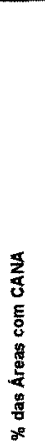 & 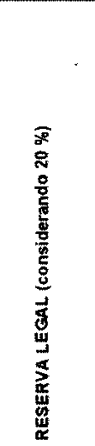 & 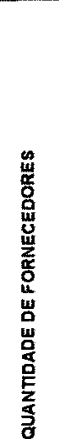 & 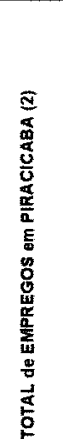 & 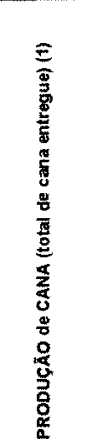 \\
\hline UPAs com canta-de-açúcar (1) & 1.040 & 23.156 & & & & & & & 100 & & 400 & 4.631 & & & 1.928 .375 \\
\hline Total UPAs Georeferenciadas com cana (1) & 882 & 20.580 & & & & & & & 85 & & & 4.112 & & & 1.712 .848 \\
\hline Total UPAs Georeferenciadas usachs no levarkamento (1) & 702 & 10.519 & 359 & 343 & 370 & 3.304 & 4 & 7215 & 80 & 51. & 100 & 2.104 & & & 876.2330 \\
\hline Area utilizada em relaçato ao total de cana dos Fonecedores (1) & & 10.519 & & & & & & & & & 460 & & & & \\
\hline UPAs em àrea de restriçâo total a quema (Entomo imedato) (1) & 89 & 1.570 & & & & & & & & & 86 & & & & 130.781 \\
\hline Área total do Entomo Imediato $(1)^{* t}$ & 12.073 & & & & & & & & & & & 2.415 & 72 & & \\
\hline Procução de cana (total de cara entregue) (i) & & 23.156 & & & 30.821 & & & & & & & 385.779 & $* 852$ & 4.632 & \\
\hline Responsäveis peias UPAs (1) & & & & & & & & & & & & & 532 & & \\
\hline Reflexos sobre a măo-de-obra na área agricola (2) & & & & & 74 & & & & & & & 926 & & & \\
\hline ATR Medio safra 2004/05 em Kg/t & 140 & & & & 4.317 .097 & & & & & & & 140 & & & \\
\hline Produtivicade Méda (1) & 83 & & & & 83 & 275.223 & & & & & & 83 & & & \\
\hline Total apurado pela produçáo de cana (Rencta Bruta) em R\$ (3) & 66.041 .280 & & & & 1.055 .530 & & & & & & & 13.211 .816 & & & \\
\hline Impostos referentes a cara dos Fornecedores em R\$ $(2)^{21 *}$ & 18.283 .750 & & & & & & & & & & & 3.857 .790 & & & \\
\hline
\end{tabular}

(1) Banco de dados AFOCAPI, (2004 e 2005); (2) (ORPLANA, 2004) (2) *** Impostos gerados: R $\$ 10,00 /$ tonelada de cana (3) Valor médio do ATR safra 2004/05 foi de * agregados + responsáveis; R\$0,2445 (CONSECANA, 2005) *^ Anhumas, Ártemis/Noiva da Colina, Santa Olimpia/Santana, Tanquinho, Tupi \& Bartira Conforme levantamento realizado pela AFOCAPI (2004), em $1.000 \mathrm{~m}$ das áreas urbanizadas.

\section{Páginas 109 e 110 onde se lề "Conclusões" leia-se:}

- O município de Piracicaba possui 852 Fornecedores ativos, dos quais 532 são os titulares, que cultivam 23.156 ha de cana-de-açúcar em 1.040 UPAs, sendo que $82 \%$ delas possuem até trinta ha.

- Metade das unidades de produção dos Fornecedores apresenta algum tipo de interferência em APPs, sendo que metade dessas áreas de interferência não ultrapassa 0,5 ha.

- Aproximadamente $8,5 \%$ das unidades de produção dos Fornecedores têm cana-de-açúcar cultivada, ao menos parcialmente, em área com restrição total à queima.

- Eliminada a cana-de-açúcar dessas áreas com interferência em APPs e áreas com restrição total à queima, estima-se haver redução de $11 \%$ na produção de cana-de-açúcar dos Fornecedores do município. 
Dados Internacionais de Catalogação na Publicação (CIP)
DIVISĀO DE BIBLIOTECA E DOCUMENTAÇĀO - ESALQ/USP

\section{Farhat, Marcos}

Subsidios para adequar a canavicultura dos fornecedores de Piracicaba à legislação ambiental / Marcos Farhat. - - Piracicaba, 2005.

121 p. : il.

Dissertação (mestrado) - - Escola Superior de Agricultura Luiz de Queiroz, 2005.

Bibliografia.

1. Cana-de-açúcar 2. Colheita 3. Degradação ambiental 4. Economia agricola 5. Impacto social 6. Legislação ambiental 7. Mecanização agricola 8. Produtor rural 9. Queimada 10. Recursos naturais - Preservação I. Título

CDD 633.61

"Permitida a cópia total ou parcial deste documento, desde que citada a fonte - 0 autor" 
Minha Terra tem palmeiras?

Não. Minha Terra tem engenhocas de rapadura, cachaça e açúcar (...)

Tem cana caiana e cana crioula,

Cana pitu, cana rajada, cana-do-governo

e muitas outras canas e garapas (...)

Carlos Drummond de Andrade 


\section{Dedico este trabalho}

A Deus, meu guia de luz.

Aos meus pais Said Farhat Filho e Maria Eunice Lichti Farhat, pelo incentivo, por toda vossa dedicação, abdicação, pela confiança em meus feitos, e pelo amor que a mim dispensam. Meus principios e minha eterna gratidão.

À minha amada esposa, mulher e companheira, fonte inspiradora, Fátima Cristiane Lopes Goularte Farhat, pelo apoio, pela paciência, dedicação, por me encorajar e pelas orientações de fundamental importância para a confecção do meu trabalho. Todo meu Amor.

Ao meu "guri" Marcelo Goularte Farhat, que em tão boa hora me chegou, e fez aumentar ainda mais a minha alegria pelo bem viver. Muita energia, paz, alegria, esperança e harmonia em minh'alma. Bem vindo.

Aos meus queridos Irmãos e suas Familias, que me apoiaram em momentos difíceis, além do respeito e carinho, e ainda que longe, acompanham sempre meu caminho. Fraternos.

Ao meu querido avô e amigo Moacyr Alberto Lichti por ter me incentivado aos livros e à leitura. Saudade. (in memorian).

A todos meus familiares, pelas tradições preservadas ao longo da nossa história com a mesma alegria de sempre. "Salam u Farhat" 


\section{AGRADECIMENTOS}

Ao Prof. Dr. Marcos Silveira Bernardes, pela amizade e ensinamentos como orientador, no trabalho de pesquisa e sua condução.

Aos professores do Departamento de Fitotecnia, Antonio Luiz Fancelli, Durval Dourado Neto, Edgar Gomes Ferreira de Beauclair, Ederaldo José Chiavegato, Pedro Jacob Christoffoletti; Departamento de Máquinas Agrícolas, Tomaz Caetano Cannavam Ripoli, da ESALQ/USP, pelas boas aulas e sugestões, apoio e compreensão durante a minha estada no curso. Todo meu respeito.

À Associação dos Fornecedores de Cana de Piracicaba - AFOCAPI e à Cooperativa dos Plantadores de Cana do Estado de São Paulo - COPLACANA, suas Diretorias, especialmente aos Senhores José Coral - Presidente destas entidades, ao $\mathrm{Eng}^{\circ} \mathrm{Agr}^{\circ}$ Arnaldo Antônio Bortoletto - Diretor Gerente da COPLACANA, ao Sr. Amâncio José Geraldi - Vice-Presidente da AFOCAPI, pela oportunidade dada para que eu pudesse realizar o Mestrado. Minha gratidão. Também aos amigos do Departamento Técnico Agronômico - DTA destas entidades, em especial ao companheiro Marcos Roberto Lunardi, pelo apoio.

À Universidade de São Paulo, Escola Superior de Agricultura "Luiz de Queiroz", Curso de Pós-Graduação em Fitotecnia. 
Aos colegas de Pós-Graduação que me apoiaram e me incentivaram durante todo o curso.

Ao colega $\mathrm{Eng}^{\circ} \mathrm{Agr}^{\circ} \mathrm{Dr}$. Edson Teramoto pela contribuição e apoio à minha dissertação e pela participação na Banca do meu Exame de Qualificação.

Ao Prof. Dr. Gil Miguel de Souza Câmara do Departamento de Fitotecnia e Prof. Dr. Carlos Alberto Vettorazzi, do Departamento de Irrigação e Drenagem, pelas participações na Banca do meu Exame de Qualificação e suas valiosas contribuições para a melhoria do meu trabalho.

Ao Prof. Dr. Gerd Sparovek do Departamento de Solos e Nutrição de Plantas pela contribuição e co-orientação do trabalho.

Ao Eng ${ }^{\circ}$ Agr $^{\circ}$ Alberto G. O. Pereira Barretto, Pós-Graduando da ESALQ/USP, pela solicitude, dedicação e pelo trabalho realizado na formatação dos dados por meio do SIG. Valorosa contribuição.

À querida Luciane Ap. Lopes Toledo, Secretária do Programa de Pósgraduação em Fitotecnia do Departamento de Produção Vegetal, ESALQ/USP, pela valorosa colaboração.

A todos que, direta ou indiretamente, colaboraram para a realização dessa dissertação. 


\section{SUMÁRIO}

Página

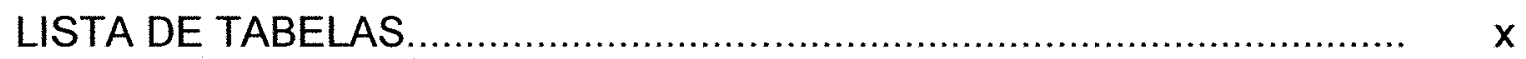

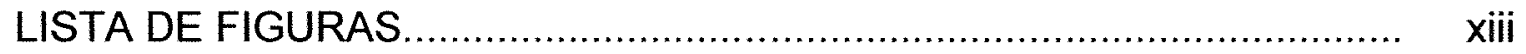

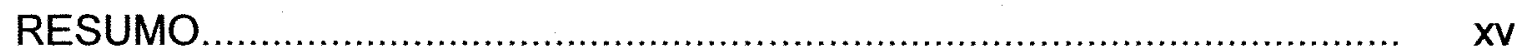

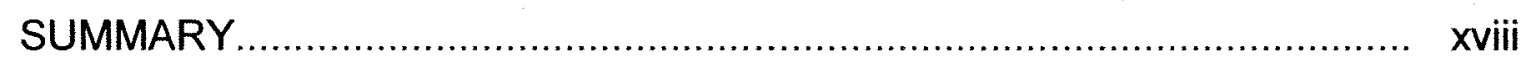

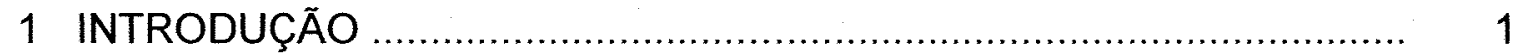

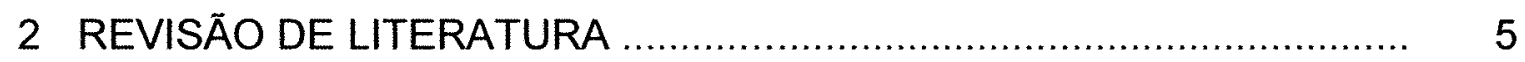

2.1 A cana-de-açúcar no Brasil ..................................................... 5

2.1.1 Origem e evolução da cultura da cana-de-açúcar no País .............. 5

2.1.2. Produção de cana-de-açúcar no Brasil, distribuição por regiões e estados .................................................................. 9

2.1.3 Produção de açúcar e álcool no Brasil, distribuição por regiões e "ranking" de exportação ....................................................... 14

2.2 Estabelecimento de Piracicaba como municipio canavicultor ............. 18

2.2.1 Evolução da cultura no município .......................................... 18

2.2.2 Características do cultivo de cana-de-açúcar no município............... 23

2.3 Importância dos Fornecedores na produção de cana-de-açúcar.......... 24

2.3.1 Fornecedores de cana do Brasil........................................... 24

2.3.2 Fornecedores de cana do Estado de São Paulo........................... 25

2.3.3 Fornecedores de cana do município de Piracicaba ...................... 35

2.3.3.1 Os Fornecedores $e$ as suas Entidades de Classe....................... 35

2.4 Histórico da colheita de cana-de-açúcar no Brasil........................... 42

2.4.1 Sistemas de colheita....................................................... 45

2.4.2 Queima da palha da cana-de-açúcar para efeito de colheita........... 49 
2.4.3 Legislação vigente e sua relação com os Fornecedores de cana. $\quad 50$

2.4.4 Das questões do trabalho .................................................... 54

2.4.5 Utilização do palhiço para a produção de energia .......................... 62

2.5 . Áreas de Preservação Permanente - APPs..................................... 63

2.5.1 Criação de mata ciliar, a preservação dos mananciais e a Constituição Federal.....................................................................

2.6 Diagnóstico das UPAs do município de Piracicaba para Queima de cana, APPs e RLs.

2.7 Alternativas de uso em áreas com restrição à cultura da cana -deaçúcar

2.7.1 Utilização do Sistema Agroflorestal SAF-CANA ............................. 67

2.7.2 Utilização de reflorestamento: Pólo Industrial de Base Florestal...... 70

2.7.3. Sistemas de produção de oleaginosas no município de Piracicaba, com ênfase para a soja \& cana-de-açúcar.

3 METODOLOGIA.

3.1 Área de estudo.

3.2 Banco de dados e cruzamento das informações: Consultas e Buscas.

3.3 Caracterização quantitativa dos Fornecedores de cana.

3.4 Caracterização quantitativa das UPAs

3.4.1 Numero de UPAs que devem se adequar, reflexo na produção e a 78 mão-de-obra.

4 RESULTADOS

4.1 Perfil dos Fornecedores de Cana do município de Piracicaba.

4.2 Perfil das UPAs utilizadas pelos Fornecedores de Cana do município de Piracicaba.

4.2.1 UPAs com restrição total à queima da palha de cana.

5 DISCUSSÃO.

5.1 Perfil dos Fornecedores da cana de Piracicaba. 
5.2 A restrição à Queima da palha de cana na Região do Entorno do município

5.3 Fornecedores a cana-de-açúcar e o Código Florestal....................... 101

5.4 Sugestões para a diversificação de culturas..................................... 105

5.5 Outras Considerações................................................................... 106

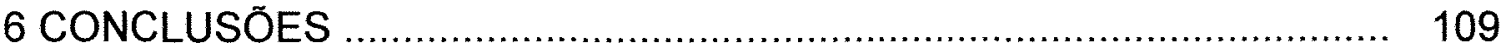

REFERÊNCIAS BIBLIOGRÁFICAS .................................................. 111 


\section{LISTA DE TABELAS}

Página

1 Produção de cana-de-açúcar no Brasil safras 1999/2000, 2000/01 e 2001/02, 2002/03 e 2003/04, por estado, expressa em toneladas.... 10

2 Área de produção de cana no Brasil nas safras 1999/2000, 2000/2001, 2001/2002, 2002/2003 e 2003/2004, por região, expressa em mil ha.

3 Produção de cana-de-açúcar no Brasil nas safras 1999/2000, 2000/2001, 2001/2002, 2002/2003 e 2003/2004, por região, expressa em mil toneladas.

4 Área cultivada em hectare, no Estado de São Paulo em 1995 e 1996.

5 Produção brasileira de açúcar e álcool nas safras 1999/2000, 2000/01, 2001/02, 2002/03 e 2003/04 por região, expressa em hectares.

6 Produção de álcool no Brasil nas safras 1999/2000, 2000/01, 2001/02, 2002/03 e 2003/04, por região, expressa em metros cúbicos.

7 Número de unidades industriais na safra 2003/04..

820 paises maiores importadores de açúcar no Brasil no ano de 20043 e respectivas quantidades importadas, expressas em toneladas e em dólares dos EUA. 
9 Estratificação da produção de cana-de-açúcar em número de Fornecedores e em toneladas, para o Estado de São Paulo.

10 Área cultivada pelos Fornecedores de cana do Estado de Dão Paulo.

11 Distribuição da produção por região denominada pela ORPLANA

12 Resultados tecnológicos e financeiros da safra 2003/04 por associação de Fornecedores, associadas à ORPLANA.

13 Distribuição da produção por Associação de Fornecedores ligada a ORPLANA

14 Resultados tecnológicos da safra 2004/05 por Associação de Fornecedores, ligadas à ORPLANA.

15 Produção equivalente de açúcar e álcool.

16 Estratificação geral dos Fornecedores de cana do Estado de São Paulo na safra 2004/05.

17 Empregos diretos gerados no âmbito dos Fornecedores de cana do Estado de São Paulo.

18 Estratificação das UPAs da regional agrícola de piracicaba, Estado de São Paulo, 1995/96.

19 Apresentação por tipo de cultura na região agrícola de Piracicaba

20 Quadro evolutivo da eliminação da queima da lei 11.241/2002 e seu decreto $n^{\circ} 47.700 / 2003$. apresenta a área mecanizável, nãomecanizável e percentagem de eliminação de queima.

21 Custo de implantação da lavoura e produção padrão para cana planta dos Fornecedores de cana da macro-região de Piracicaba, por ha, com atualização em 15/04/2005

22 Estratificação geral dos Fornecedores de cana do municipio de Piracicaba em relação ao peso de cana limitado por faixa de entrega 
23 Número de Fornecedores relacionados ao número de UPAs e área de produção

24 Estrato da quantidade de módulos rurais do município de piracicaba com relação às UPAs.

25 Área aproximada em ha da região do entorno imediato município de Piracicaba, sede e principais bairros e/ou distritos.

26 Levantamento das UPAS localizadas na área do entorno imediato de $1.000 \mathrm{~m}$, com restrição total à queima de cana dos municipios de Piracicaba e seus limítrofes área de atuação da AFOCAPI

27 UPAS integradas na analise conjunta das bases de dados de sistemas de georeferenciamento da AFOCAPI e dos sistemas de informações geográficas (sig) da ESALQ/USP, com percentuais de interferência em APP

28 Resultados pelo número de módulos rurais relacionados com área de cana em APP.

29 Quadro comparativo dos resultados obtidos entre as UPAS aproveitadas e possibilitadas de visualização com os dados gerais da Tabela 23 ..

30 Quantidade de UPAS relacionadas à quantidade em metros quadrados de interferência em APP

31 Quadro geral de resultados 


\section{LISTA DE FIGURAS}

Página

1 Engenho São Jorge dos Erasmos. Fonte Elo, 2000

2 Sistema global de colheita com sub-sistemas e interfaces. interface 1: queima, desfolhante, sistema de plantio etc; interface 2: transbordo, limpeza etc; interface 3: descarregamento, sonda, limpeza etc. (Ripoli, 1975)

3 Área de cana com declividade maior que $12 \%$, cana queimada e corte manual, com impedimentos à colheita mecanizada. foto: Marcos Farhat, 2003.

4 Classificação do uso da terra do município de Piracicaba, conforme apresentado no Plano Diretor Rural, (2003).

5 Estrato do número de UPAS em relação a área de produção dos Fornecedores

6 Percentual das áreas produtivas relacionadas ao percentual de produção.

7 Estrato das áreas médias por categoria de UPAS e Fornecedores.

8 Área do entorno imediato do município de Piracicaba, com distribuição espacial da UPAs georreferenciadas, com distancia de $1.000 \mathrm{~m}$, conforme levantamento realizado pela AFOCAPI, 2005 
9 Distribuição das UPAs dos Fornecedores de cana associados da AFOCAPI na macro-região de Piraciaba........................................... 93

10 Área total do município de piracicaba com a distribuição espacial das UPAS, georreferenciadas. Fonte: AFOCAPI, 2005.

11 Sobreposição de temas do Sistema de Georreferenciamento da e do Sistema Informações Geográficas (SIG) TNT mips $6.8 \mathrm{com}$ um "buffer" gerado de 30, 50 e 100 metros, conforme exigência da legislação 


\title{
SUBSÍDIOS PARA ADEQUAR A CANAVICULTURA DOS FORNECEDORES DE PIRACICABA À LEGISLAÇÃO
} AMBIENTAL

\author{
Autor: MARCOS FARHAT \\ Orientador: Prof. Dr. MARCOS SILVEIRA BERNARDES
}

\section{RESUMO}

A atual legislação brasileira exige adequações no sistema de produção agrícola, com peculiaridades à cultura da cana-de-açúcar. Esta prevê a eliminação gradativa da queima como método facilitador do corte. No município de Piracicaba apenas $30 \%$ das áreas com essa cultura oferece possibilidade de colheita mecanizada e o restante possui alguma restrição. O Código Florestal Brasileiro obriga a restauração de Áreas de Preservação Permanente - APPs e de Reserva Legal - RLs. Piracicaba é tradicionalmente produtora de cana-deaçúcar e possui expressivo número de Fornecedores de cana com perfil característico de pequenos e médios produtores. A legislação impõe suas regras sobre as Unidades de Produção Agrícolas - UPAs sem que haja um estudo mais aprimorado sobre o uso dessas UPAs. Há necessidade de maior conhecimento quanto aos Fornecedores e seus agregados, às características específicas de cada UPA e à avaliação do efeito da legislação sobre estes. Este trabalho descreve e discute os reflexos da legislação sobre as UPAs, sistemas de 
colheita e as exigências para a adequação da lavoura canavieira. Para tanto, considera algumas características do município: 1) suas bases históricas, considerando que conhecer e entender o passado proporciona o progresso no presente e o desenvolvimento no futuro e $o$ aprimoramento para qualquer setor de atividade; 2) distribuição das UPAs na paisagem; 3) impacto sócioeconômico na atividade. Como sintese do problema da pesquisa dois objetivos são pautados: 1) traçar o perfil dos Fornecedores de Piracicaba e das suas UPAs; 2) avaliar o impacto da legislação sobre a produção de cana nas UPAs e nos Fornecedores. Como hipótese a pesquisa postula que a total aplicação da legislação sem a contraposição de incentivos afetará a produção canavieira de Piracicaba. Utilizou-se o banco de dados de produção, mapas georreferenciados e Sistemas de Informações Geográficas (SIG). A base de dados atual apresenta o perfil dos Fornecedores com relação as suas áreas de produção em números de UPAs, tamanhos, localização geográfica, produtividade, produção e número de Fornecedores, porém, deixa a desejar no que se refere à especificidade de cada área. Estão quantificados em $82 \%$ os casos menores que dois módulos de produção agrícola, ou seja, abaixo de 20 ha. Número expressivo de Fornecedores possui agregados (sócios na produção), conferindo maior dificuldade de adaptação às novas situações. Aplicada integralmente a legislação ambiental, verifica-se que haverá uma diminuição na área produtiva, a qual representará diminuição aproximada na quantidade de cana de $31 \%$ ou 600 mil toneladas, o que interferiria diretamente na renda bruta dos Fornecedores. Os entraves para a adoção de outras culturas para o cumprimento das obrigações legais não são intrínsecos aos Fornecedores, porém são principalmente devido às características da própria tecnologia como a sua adaptabilidade às condições locais, a segurança do mercado para os produtos e a falta de um programa oficial de assistência técnica. No entanto, nota-se que havendo alguma forma de incentivo ou fomento, os Fornecedores são passiveis de aceitarem as inovações. Porém, a simples imposição legal, 
diminuindo e suprimindo a produção de cana-de-açúcar e as suas rendas, significam entraves para estabelecer a legislação. 


\title{
SUBSIDIES TO ADAPT THE PIRACICABA CANE GROWERS AGRICULTURE TO THE ENVIRONMENT LAWS
}

\author{
Author: MARCOS FARHAT \\ Adviser: Prof. Dr. MARCOS SILVEIRA BERNARDES
}

\section{SUMMARY}

The current Brazilian legislation demands adaptations of the of agricultural production system, with peculiarities to the sugar-cane crop. This Law foresees the elimination of the burn as to facilitate method of the harvesting. In the municipal district of Piracicaba only $30 \%$ of the areas with that culture offer possibility of automated crop and the remaining possess some restriction. The Brazilian Forest Code forces the restoration of Areas of Permanent Preservation - APPs and of Legal Reservation - RLs. Piracicaba is traditionally producing of sugar-cane and it possesses expressive number cane Cane Growers, with characteristic profile of small and medium producers. The legislation imposes its rules on the Agricultural Units of Production - UPAs without a detailed study on the use of those UPAs. It is necessary a larger knowledge with relationship to the Cane Growers and its attachés, to the specific characteristics of each UPA and the evaluation of the effect of the legislation on these. This work describes and discusses the reflexes of the legislation on UPAs, crop systems and the demands for the adaptation of the sugar cane agriculture. Then, it considers some characteristics of the municipal district: 1) its historical bases, considering that to know and to understand the 
past provides the progress in the present and the development in the future and the improvement for any activity section; 2) distribution of UPAs in the landscape; 3 ) socioeconomic impact in the activity. As synthesis of the problem of the research two objectives is pointed: 1) to trace the profile of the Cane Growers of Piracicaba and of its UPAs; 2) to evaluate the impact of the legislation about the cane production in UPAs and in the Cane Growers. As hypothesis the research postulates that total application of the legislation without the opposition of incentives will affect the sugar cane production in Piracicaba. It was used the production database, maps georreferenciados and Systems of Geographical Information (SGI). The current base of data presents the profile of the Cane Growers related to its production areas in numbers of UPAs, sizes, geographical location, productivity, production and number of Cane Growers, even so, he/she leaves to want in what he/she refers to the particularity of each area. Are quantified in $82 \%$ the smaller cases with two modules of agricultural production, that is to say, below 20 there is. Expressive number of Cane Growers possesses attachés (partners in the production), checking larger adaptation difficulty to the new situations. Applied the environmental legislation integrally will induce a decrease in the productive area, representing a decrease approached in the amount of cane of $31 \%$ or 600 thousand tons and interfering directly in the gross income of the Cane Growers. The difficulties for the adoption of another cultures for the execution of the legal obligations are mainly due to the characteristics of the own technology, as its adaptability to the local conditions, the safety of the market for the products and the lack of an official program of technical attendance. Even so, the simple legal imposition, decreasing and suppressing the sugar-cane production and its, induces the difficulties to the establishment of legislation. 


\section{INTRODUÇÃO}

Pertencente ao gênero Saccharum da família Poaceae, a cana-de-açúcar é uma planta conhecida desde os primórdios da civilização, e cultivada por horticultores neolíticos desde 8.000 a.C. Antes da era Cristã, em 287 a.C., a cana-de-açúcar já foi descrita por Theopharstus, como "o mel que está em um bastão" (UNICA,2004).

Segundo Godoy (1972), as diversas espécies de cana-de-açúcar, têm origens diferentes. As canas conhecidas como "nobres" ou "tropicais" teriam se originado da Oceania, particularmente de Nova Guiné. Por outro lado, as canas "indianas", "japonesas" e "chinesas" seriam originárias do continente asiático. Daniels \& Roach (1987) citam como sendo originária do Sudeste Asiático, na grande região em Nova Guiné e Indonésia. Brandes (1958) cita a espécie $S$. spontaneum L. como sendo a espécie básica que, através de poliploidia e hibridação, originou outras espécies, como S. robustum Jesw. e S. officinarum L. Para Fauconnier \& Bassereu (1975), a S. officinarum se originou da S. robustum Jesw.

Segundo Figueiredo et al. (1995) e Matsuoka et al. (1999), inicialmente cultivava-se principalmente a espécie $S$. officinarum $L$. Com o passar do tempo, entretanto, cultivares desta espécie passaram a sofrer problemas de doenças e de adaptação ecológica. Surgiram então os programas de melhoramento genético para obtenção de híbridos interespecíficos (Saccharum spp.) resistentes e mais bem adaptados para as diversas condições em que essa cultura se expandiu pelo mundo. A cana-de-açúcar é cultivada numa ampla faixa 
de latitude, de $35^{\circ} \mathrm{N}$ a $30^{\circ} \mathrm{S}$, e em altitudes que variam desde o nivel do mar até $1.000 \mathrm{~m}$ (Magalhães, 1987).

O melhorista sempre tem como meta obter variedades com elevada produtividade associada a outros caracteres desejáveis. Mas, estes são os resultados de um sistema dinâmico que vai continuamente variando, desde a germinação ou estabelecimento da planta até a sua maturidade ou colheita. $E$ esse modelo de mudanças não é o mesmo para todos os genótipos, num mesmo ambiente, ou para um mesmo genótipo em distintos ambientes (Allard \& Bradshaw, 1964). Além disso, ao longo dos anos o ambiente vem se modificando, tanto pelo uso continuo da terra como pelas inevitáveis mudanças tecnológicas, razão da necessidade de melhoramento genético contínuo.

Ao final do século $X X$, o Brasil se tornou o maior produtor mundial de cana-de-açúcar, de açúcar e de álcool do mundo (Balsadi et al., 1996). Essa liderança foi atingida em função da criação do Proálcool, em 1975, um programa governamental de incentivo à produção de álcool combustivel.

A agricultura canavieira no Brasil, especialmente no estado de São Paulo, tem passado por transformações na busca da qualidade e menores custos para proporcionar competitividade e supremacia frente o mercado internacional.

A recuperação de preços da matéria prima e produtos acabados, como o açúcar e o álcool, e o mais recente avanço em direção à produção de energia utilizando a biomassa, e a legislação ambiental, têm direcionado o setor a mudanças no sistema de produção.

Para tanto, os setores de Pesquisa e Desenvolvimento - P\&D têm apresentado inovações tecnológicas que vão desde a sistematização das áreas, tipos de plantio, condução da lavoura, melhoria das colhedoras e dos meios de transporte, até o descarregamento nas unidades industriais. Entretanto, ainda carece de inovações e possíveis soluções para as dificuldades particulares dos pequenos e médios produtores de cana-de-açúcar.

Mudanças têm sido buscadas para atender as necessidades de mudanças dos sistemas de produção, otimizando e maximizando a produção, 
reduzindo custos; fortalecendo a atividade, frente aos mercados nacional e internacional, aumentando a eficiência e atendendo as exigências do ambiente, sociais e econômicas. Entre tais transformações, aquelas relativas às adequações ambientais de diminuição da queima da palha para efeito de colheita como forma de despalha para facilitar o corte manual, regida pela Lei 11.241/2002 e Decreto 47.700/2003, e o cumprimento da Lei 4.771/1965 (Código Florestal) podem ser consideradas as principais. $E$, entre as principais mudanças, estão aquelas relacionadas à colheita, com a substituição do corte manual pelo mecanizado, e o ajustamento de áreas de preservação.

Portanto, a cadeia produtiva sucroalcooleira, suas ramificações e o poder público, têm motivos relevantes para investir em tecnologias em busca da sustentabilidade.

Neste contexto, a colheita representa uma parte considerável do custo de produção, sendo a sua modalidade mecanizada apontada como uma possivel solução. Além do custo, a indisponibilidade de mão-de-obra e a legislação sobre a queima da cana também contribuem para o avanço da mecanização total na lavoura canavieira. Porém, existem algumas restrições inerentes à esta tecnologia atual, como por exemplo, o relevo ondulado de algumas regiões brasileiras, dentre elas o município de Piracicaba, SP - Brasil, objeto deste trabalho

Este trabalho descreve e discute os reflexos da legislação ambiental sobre as UPAs, sistemas de colheita e as exigências para a adequação da lavoura canavieira. Para tanto, considera algumas características do município: 1) suas bases históricas, considerando que conhecer e entender o passado proporciona o progresso no presente e o desenvolvimento no futuro e o aprimoramento para qualquer setor de atividade; 2 ) distribuição das UPAs na paisagem; 3) impacto sócio-econômico na atividade.

A cana-de-açúcar, marcada inicialmente pelo lirismo de Theopharstus serve como base da discussão da sua relevância nos dias atuais e 
representando um lastro considerável do agronegócio brasileiro, paulista e do municipio de Piracicaba.

Como síntese do problema da pesquisa dois objetivos são pautados: 1) traçar o perfil dos Fornecedores de cana do município de Piracicaba e das suas Unidades de Produção Agrícola; 2) avaliar o impacto da legislação ambiental sobre a produção de cana nas áreas dos Fornecedores. Como hipótese a pesquisa postula que a total aplicação da legislação sem a contraposição de incentivos afetará a produção canavieira no município de Piracicaba. 


\section{REVISÃO DE LITERATURA}

\subsection{A cana-de-açúcar no Brasil}

\subsubsection{Origem e evolução da cultura da cana-de-açúcar no País}

Um breve relato histórico demonstra a importância da cana-de-açúcar na construção do Brasil, na sua cultura e na sua economia. Notoriamente nestes anos todos, o setor passou por grandes transformações até chegar a uma agroindústria de importância econômica, social e ambiental, estando entre as culturas agrícolas mais relevantes para o país. A produção de alimentos era um dos propósitos para a descoberta de novas terras na época das Grandes Navegações. Áreas cultiváveis na Europa estavam escassas, portanto restringiam o desenvolvimento e a prosperidade de espécies de plantas como a cana-de-açúcar, cujo produto, o açúcar, era escasso e caro no Velho Continente. Portugal plantava cana nas ilhas de Cabo Verde, Açores e Madeira. Ainda assim, eram poucas as terras apropriadas para a cultura (UNICA, 2004).

Em 1532, Martin Afonso de Souza, cumprindo ordem de D. João III, desembarca na Capitania de São Vicente com a cana-de-açúcar, que curiosamente foi levada da Pérsia (Irã) pelos Árabes até a Europa banhada pelo mediterrâneo, depois para a Espanha, África, China, chegando na llha da Madeira no século XV. Um dos grandes fatores para o desenvolvimento do ocidente antigo, a Europa, foi sua invasão no novo mundo, as Américas, e no Brasil a chegada dos Portugueses no ano de 1500. Funda-se naquele ano, o 
engenho São Jorge dos Erasmos ${ }^{1}$, inaugurando o setor sucroalcooleiro brasileiro. O Engenho foi construído por ordem do próprio Martin Afonso e o que ainda resta de suas construções está sob responsabilidade da Universidade de São Paulo - USP (Lichti et al., 1986). Ainda segundo o autor o engenho passa por ter sido o primeiro construído na Capitania de São Vicente e em todo o Brasil. Entretanto, a pesquisa vai apurando que, na fase de Martim Afonso, aquele Engenho teria sido precedido pelo Engenho de São João, de José Adorno, fundado em 1532 e com produção de açúcar e aguardente iniciada em 1533. Assim começou a agricultura comercial no Brasil. A chegada da cana iniciou uma nova era na história brasileira. Estava lançada a semente do futuro, da independência e da liberdade do Brasil (Fernandes, 1984).

O plantio espalhou-se no solo fértil de massapé, com a ajuda do clima tropical quente e úmido e da mão-de-obra escrava trazida da África. Essa atividade na nova colônia enriqueceu Portugal e espalhou o açúcar brasileiro por toda a Europa (UNICA, 2004).

1 São Jorge dos Erasmos é tido como primeiro engenho do Brasil segundo alguns historiadores. $\mathrm{Na}$ época de sua instalação pertencia à Capitania de São Vicente. Posteriormente, este património passou a pertencer ao municipio de Santos,SP. 


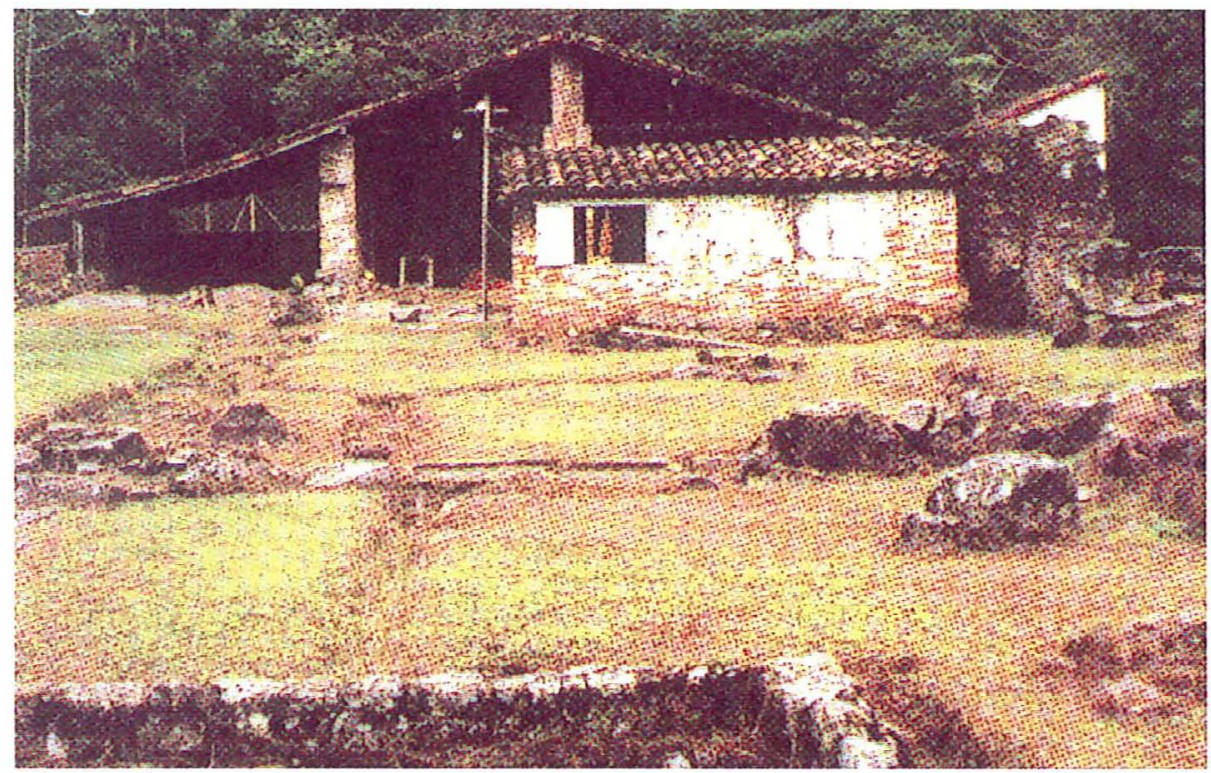

Figura 1 - Engenho São Jorge dos Erasmos. Fonte: Lichti et al. (1986)

Posteriormente, em 1535, Jerônimo de Albuquerque funda o primeiro engenho de açúcar do Nordeste, em Pernambuco nas proximidades de Olinda, chamado denominado Nossa Senhora da Ajuda.

A capitania mais importante na época do ciclo da cana era a de Pernambuco, que pertencia a Duarte Coelho, onde foi implantado o primeiro centro açucareiro do Brasil. Logo se seguiu o despertar da Capitania da Bahia de Todos os Santos - de Francisco Pereira Coutinho - e, com o desmatamento da Mata Atlântica nativa, os canaviais expandiram-se pela costa brasileira. No entanto, diferentemente do que acontecia nas terras do norte da colônia, as capitanias de São Vicente (São Paulo) e São Tomé (Rio de Janeiro) sofriam por estarem mais distantes da metrópole e dos portos europeus. Isso encarecia o transporte do açúcar, mas não impediu que a cultura também se estabelecesse nessas áreas (UNICA, 2004).

O Nordeste e o Sudeste brasileiros estiveram ligados à cultura da cana desde o início da colonização e permanecem até hoje. Porém, com o advento do Proálcool nos anos 1970 a cultura é implantada de forma intensa nos estados do Centro-Oeste, e no Paraná, região Sul do país. Algumas regiões do 
Sudeste permanecem como importantes produtoras de cana-de-açúcar, como no Estado de São Paulo, as de Ribeirão Preto e Piracicaba.

Segundo Gonçalves \& Souza (1998) a cana-de-açúcar é uma das principais culturas agrícolas do país e a mais importante do Estado de São Paulo, ocupando 4,5 milhões e 2,7 milhões de ha, respectivamente. Este Setor está para o Brasil, como o petróleo está para o resto do mundo. É de importância vital, fonte de divisas e energia renovável que contribui para a manutenção de sua independência econômica.

A cana-de-açúcar arbitrou ao Brasil a possibilidade de um futuro seguro, com independência e liberdade, com tecnologia inovadora na agroindústria. Com a expansão das áreas de plantio nos anos 1970, visando substituir as necessidades de petróleo importado, é criado o Programa do Álcool, o Proálcool. Produzir álcool em quantidade suficiente para abastecer a frota de veículos significou expandir as áreas de plantio, incentivar os produtores rurais e as usinas a produzirem mais e mais, até que fossem atingidas áreas equivalentes a quatro milhões e meio de hectares com a cultura da cana em 2002. Desde a implantação do Proálcool, o Brasil economizou cerca de US $\$ 35$ bilhões em divisas por ter diminuído a importação de petróleo. Portanto, um setor que deve ser e está sendo modernizado a cada dia. No ano 2000 metade da produção brasileira de açúcar foi exportada, o que gerou 1,2 bilhões de dólares para a balança comercial. O Programa do Álcool de cana-de-açúcar significou, pelo menos naquele momento de alta do petróleo, a salvação para o Brasil. Não deverá ser diferente num futuro próximo. Com a desordem e as altas constantes nos preços internacionais do petróleo, o álcool pode tornar-se novamente um dos grandes esteios da economia na produção de energia por meio da Biomassa. Boas oportunidades comerciais devem surgir, tratando-se do Mecanismo de Desenvolvimento Limpo - MDL do Protocolo de Quioto. A canade-açúcar é energia concentrada em forma de açúcares e fibras, renovável, viável e faltando somente fazer parte da matriz energética brasileira (ÚNICA, 2002). 


\subsubsection{Produção de cana-de-açúcar no Brasil, distribuição por regiões e estados}

A Tabela 1 apresenta a distribuição da produção de cana-de-açúcar no Brasil. Alguns estados que não têm tradição na cultura, especialmente na Região Norte, o Amazonas e o Pará, apresentam produção de cana em menor escala. Entre os estados do Nordeste, Pernambuco e Alagoas continuam dominando a produção, embora com queda significativa, principalmente no caso de Alagoas, onde a produção baixou de aproximadamente de 25 milhões para 15,5 milhões de toneladas entre as safras de 00/01 e 01/02. No Sul, o Paraná vem se mantendo nas últimas três safras praticamente com a mesma produção. Já a produção no Sudeste apresenta o estado de São Paulo, embora com produção menor na safra 2001/2002, como o grande produtor de cana-deaçúcar do Brasil, com aproximadamente 176,5 milhões de toneladas, seguido por Minas Gerais, Rio de Janeiro e Espírito Santo (UNICA, 2004). 
Tabela 1. Produção de cana-de-açúcar no Brasil safras 1999/2000, 2000/01 e 2001/02, 2002/03 e 2003/04, por estado, expressa em toneladas

\begin{tabular}{|c|c|c|c|c|c|}
\hline & & & SAFRAS & & \\
\hline ESTADOS/SAFRA & $1999 / 2000$ & $2000 / 01$ & $2001 / 02$ & $2002 / 03$ & $2003 / 04$ \\
\hline ACRE & 0 & 0 & 0 & 0 & 0 \\
\hline RONDONIA & 0 & 0 & 0 & 0 & 0 \\
\hline AMAZONAS & 0 & 0 & 201.036 & 255.852 & 250.881 \\
\hline PARÁ & 521.339 & 527.383 & 283.406 & 311.492 & 419.514 \\
\hline TOCANTINS & 0 & 0 & 0 & 0 & 0 \\
\hline MARANHÃO & 938.174 & 799.490 & 1.094 .115 & 1.105 .114 & 1.303 .509 \\
\hline PIAUI & 218.022 & 248.289 & 273.691 & 284.180 & 322.802 \\
\hline CEARÁ & 131.166 & 65.671 & 73.637 & 88.954 & 63.907 \\
\hline R. G. NORTE & 1.892 .617 & 2.388 .270 & 2.064 .515 & 2.681 .857 & 2.001 .104 \\
\hline PARAIBA & 3.418 .496 & 3.594 .320 & 4.001 .051 & 4.335 .516 & 3.496 .638 \\
\hline PERNAMBUCO & 13.320 .164 & 14.366 .994 & 14.351 .050 & 14.891 .497 & 11.173 .403 \\
\hline ALAGOAS & 19.315 .230 & 25.198 .251 & 23.124.558 & 22.645 .220 & 17.068 .453 \\
\hline SERGIPE & 1.163 .285 & 1.413 .639 & 1.316 .925 & 1.429 .746 & 1.653 .046 \\
\hline BAHIA & 2.098 .231 & 1.920 .653 & 2.048 .475 & 2.213 .955 & 1.988 .762 \\
\hline \multicolumn{6}{|l|}{ NORTEI } \\
\hline NORDESTE $\left(^{*}\right)$ & 43.016 .724 & 50.522 .960 & 48.832 .459 & 50.243 .383 & 39.742 .019 \\
\hline MINAS GERAIS & 13.599 .488 & 10.634 .653 & 12.204 .821 & 15.599 .511 & 18.608 .412 \\
\hline ESPIRITO SANTO & 2.126 .902 & 2.554 .166 & 2.010 .903 & 3.292 .724 & 2.952 .895 \\
\hline RIO DE JANEIRO & 4.953 .176 & 3.934 .844 & 3.072 .603 & 4.478 .142 & 4.577 .007 \\
\hline$\underline{\text { SÃO PAULO }}$ & 194.234 .474 & $\underline{148.256 .436}$ & $\underline{176.574 .250}$ & 192.486 .643 & 207.572 .538 \\
\hline PARANÁ & 24.351 .048 & 19.320 .856 & 23.075 .623 & 23.892 .645 & 28.485 .775 \\
\hline SANTA CATARINA & 0 & 0 & 0 & 0 & 0 \\
\hline R. G. SUL & 0 & 0 & 80.262 & 102.999 & 93.836 \\
\hline MATO GROSSO & 10.110 .766 & 8.669 .533 & 10.673 .433 & 12.384 .480 & 14.349 .933 \\
\hline
\end{tabular}


Tabela 1. Produção de cana-de-açúcar no Brasil safras 1999/2000, 2000/01, 2001/02, 2002/03 e 2003/04, por estado, expressa em toneladas

\begin{tabular}{lccccc}
\hline \multicolumn{1}{c}{ ESTADOS/SAFRA } & $1999 / 2000$ & $2000 / 01$ & $2001 / 02$ & $2002 / 03$ & $2003 / 04$ \\
\hline MATO GROSSO DO SUL & 7.410 .240 & 6.520 .923 & 7.743 .914 & 8.247 .056 & 8.892 .972 \\
GOIÁS & 7.162 .805 & 7.207 .646 & 8.782 .275 & 9.922 .493 & 13.041 .232 \\
& & & & & \\
CENTRO-SUL & 263.948 .899 & 207.099 .057 & 244.218 .084 & 270.406 .693 & 298.574 .600 \\
$\quad$ BRASIL & 306.965 .623 & 257.622 .017 & 293.050 .543 & 320.650 .076 & 338.316 .619 \\
\hline
\end{tabular}

Fonte: UNICA, 2004. (*) Os dados da Região N-NE na Safra 2003/04 são referentes à situação até 01/01/2004.

Conforme a Tabela 2, o estado de São Paulo é o estado brasileiro com maior área plantada com cana-de-açúcar, alcançando na safra 2003/04 aproximadamente 2,5 milhões de ha plantados e com uma produção, conforme a Tabela 3 de 207 milhões de toneladas, o que representa aproximadamente $58 \%$ da produção nacional que foi de 358 milhões de toneladas (UNICA, 2004).

Tabela 2. Área de produção de cana no Brasil nas safras 1999/2000, 2000/2001, 2001/2002, 2002/2003 e 2003/2004, por região, expressa em mil ha

\begin{tabular}{|c|c|c|c|c|c|c|}
\hline \multirow[b]{2}{*}{ REGIÃO } & \multicolumn{6}{|c|}{ SAFRAS } \\
\hline & $1998 / 1999$ & $1999 / 2000$ & $2000 / 01$ & $2001 / 02$ & $2002 / 03$ & $2003 / 04$ \\
\hline Centro/Sul & 3.990 & 4.100 & 3.050 & 3.300 & 3.357 & 3.641 \\
\hline São Paulo & 2.900 & 2.950 & 2.180 & 2.400 & 2.413 & 2.531 \\
\hline Demais do CS & 1.090 & 1.150 & 870 & 900 & 944 & 1.110 \\
\hline$N \in N E$ & 950 & 900 & 910 & 910 & 910 & 910 \\
\hline BRASIL & 4.940 & 5.000 & 3.960 & 4.210 & 4.267 & 4.551 \\
\hline
\end{tabular}

Fonte: ÚNICA, 2004.

A Tabela 3 mostra que a produção de cana-de-açúcar do Estado de São Paulo (207.573 milhões de toneladas) correspondeu na safra 2003/04 a 69,5\% da produção da Região Centro-Sul e $57,8 \%$ do Brasil. Já a produção de açúcar do estado de São Paulo (15.173 milhões de toneladas), esta representou 74,3\% 
da Região Centro/Sul e 60,9\% do Brasil, enquanto a do álcool (8.806.942 m3) representou $67,6 \%$ da produção do Centro-Sul e $62,4 \%$ da produção brasileira (UNICA, 2004).

Tabela 3. Produção de cana-de-açúcar no Brasil nas safras 1999/2000, 2000/2001, 2001/2002, 2002/2003 e 2003/2004, por região, expressa em mil toneladas

\begin{tabular}{lcccccc}
\hline REGIÄO & \multicolumn{5}{c}{ SAFRAS } \\
\hline & $1998 / 1999$ & $1999 / 2000$ & $2000 / 01$ & $2001 / 02$ & $2002 / 03$ & $2003 / 04$ \\
São Paulo & 199.314 & 194.235 & 148.257 & 176.574 & 190.628 & 207.573 \\
Demais C-S & 70.209 & 69.735 & 58.843 & 67.645 & 77.920 & 91.025 \\
Ne NE & 45.141 & 36.444 & 49.291 & 47.705 & 50.463 & 60.195 \\
Centro-Sul & 269.523 & 263.970 & 207.099 & 244.211 & 268.548 & 298.597 \\
BRASIL & $\mathbf{3 1 4 . 6 6 4}$ & $\mathbf{3 0 0 . 4 1 4}$ & $\mathbf{2 5 6 . 3 9 0}$ & $\mathbf{2 9 1 . 9 2 4}$ & $\mathbf{3 1 9 . 0 1 1}$ & $\mathbf{3 5 8 . 7 9 2}$ \\
\hline
\end{tabular}

Fonte: UNICA (2004).

Conforme mostra a Tabela 4, a área com cana-de-açúcar no Estado de São Paulo é a segunda em extensão, permanecendo atrás somente da área ocupada com pastagens. Porém, a maior parte das pastagens são áreas que não têm uma atividade agrícola de grande intensidade, como por exemplo, a utilização de mecanização, mão-de-obra e insumos, portanto com menor relevância sócio-econômica comparando-se com a cultura da cana.

$\mathrm{Na}$ safra 2003/04 a área total de cana dos Fornecedores do Estado de São Paulo representou aproximadamente $26 \%$ da área total com cana no Estado, sendo aproximadamente 760 mil hă conforme Tabela 10 (ORPLANA, 2004), e 2,88 milhões de ha descrita na Tabela 4 (LUPA, 1996). 
Tabela 4. Área cultivada em hectare, no Estado de São Paulo em 1995 e 1996

\begin{tabular}{|c|c|c|c|c|c|}
\hline \multirow{2}{*}{ CULTURA } & \multicolumn{5}{|c|}{ ÁREA COM CANA NA UPA } \\
\hline & $N^{\circ}$ DE UPAS & MÍNIMO & MÉDIA ${ }^{1}$ & MÁXIMO & TOTAL em ha \\
\hline Braquiária & 147.676 & 0,10 & 51,52 & $11.222,40$ & 7.607 .461 .90 \\
\hline Cana-de-açúcar & 70.111 & 0,10 & 41,17 & $7,954,70$ & $2.886 .312,60$ \\
\hline Milho & 84.910 & 0,10 & 14,56 & $5.183,00$ & $1.235 .906,20$ \\
\hline Laranja & 35.883 & 0,10 & 24,13 & $8.593,10$ & $865.801,80$ \\
\hline Soja & 9.411 & 0,10 & 75,89 & $4.500,90$ & $714.206,60$ \\
\hline Eucalipto & 38.153 & 0,10 & 17,81 & $14.000,00$ & $679.639,20$ \\
\hline Capim-colonião & 4.352 & 0,10 & 90,95 & $6.545,20$ & $395.799,10$ \\
\hline Café & 28.399 & 0,10 & 8,07 & $1.017,00$ & $229.089,70$ \\
\hline Feijão & 18.056 & 0,10 & 8,98 & 992,00 & $162.208,30$ \\
\hline Algodão & 8.134 & 0,10 & 19,75 & $1.448,20$ & $160.651,00$ \\
\hline Pinus & 1.319 & 0,10 & 103,15 & $10.630,00$ & $136.052,20$ \\
\hline Capim-napier & 27.749 & 0,10 & 4,31 & $2.150,60$ & $119.640,10$ \\
\hline Capim-jaraguá & 2.682 & 0,10 & 23,60 & 741,00 & $63.285,50$ \\
\hline Amendoim & 2.069 & 0,10 & 29,86 & $1.839,20$ & $61.778,60$ \\
\hline Banana & 10.112 & 0,10 & 6,07 & 484,00 & $61.386,70$ \\
\hline Arroz & 11.183 & 0,10 & 4,07 & 600,00 & $45.535,00$ \\
\hline Seringueira & 2.472 & 0,10 & 16,43 & 759,00 & $40.608,80$ \\
\hline Sorgo & 2.111 & 0,10 & 16,88 & $1.024,40$ & $35.639,90$ \\
\hline Limão & 8.006 & 0,10 & 4,36 & $1.602,30$ & $34.940,30$ \\
\hline Mandioca & 10.365 & 0,10 & 2,95 & 650,00 & $30.586,40$ \\
\hline Manga & 7.008 & 0,10 & 3,64 & 158,00 & $25.483,40$ \\
\hline Tangerina & 5.981 & 0,10 & 4,22 & 345,90 & $25.228,30$ \\
\hline Batata-inglesa & 1.687 & 0,10 & 14,84 & 580,00 & $25.041,90$ \\
\hline
\end{tabular}

Fonte: Secretaria de Agricultura e Abastecimento do Estado de São Paulo, Projeto LUPA, 1996.

As informações do LUPA (1996) são oficiais, apresentadas pela Secretaria de Agricultura e Abastecimento do Estado de São Paulo, e demonstram uma diferença em relação aos dados mais atualizados apresentados pela Tabela 2. No entanto, deve-se levar em consideração que o LUPA (1996) apresenta todas as áreas com cana-de-açúcar, incluindo-se as áreas ocupadas com a cultura para a utilização na produção de cachaça, açúcar mascavo, rapadura, xarope e melaço, e como forrageira destinada à alimentação animal. A UNICA (2004) apresenta somente o total de áreas com cana-de-açúcar plantadas pelas usinas e pelos Fornecedores, destinadas à 
industrialização em açúcar cristal branco, açúcar VHP (Very Higth Polarization) e álcool carburante (anidro e/ou hidratado). Mesmo com essas considerações a diferença entre as duas bases de dados é grande.

Não houve continuidade no levantamento dos dados por parte da Secretaria de Agricultura e Abastecimento do Estado de São Paulo a partir do LUPA (1996), conforme informações obtidas desta secretaria. Portanto, as informações mais recentes sobre a área agricola, produção e produtividade referentes à cana-de-açúcar do estado de São Paulo, destinada à agroindústria sucroalcooleira, são aqueles apresentados pelas entidades de classe, como as cooperativas, associações e sindicatos, principalmente pela ORPLANA, AFOCAPI e UNICA. Tal situação aponta para a necessidade de uma base oficial com dados atualizados.

\subsubsection{Produção de açúcar e álcool no Brasil e exportação}

Na Tabela 5 verifica-se que a produção de açúcar cresceu $39 \%$ no período de cinco anos, cerca de $6,7 \%$ ao ano, enquanto a produção de álcool aumentou $6 \%$ na safra 2003/04 em relação à safra 1998/1999, representando aumento de aproximadamente em $1,2 \%$ ao ano. 
Tabela 5. Produção brasileira de açúcar e álcool nas safras 1999/2000, 2000/01, 2001/02, 2002/03 e 2003/04 por região, expressa em hectares

\begin{tabular}{ccccccc}
\hline REGIÃO CANAVIEIRA & \multicolumn{7}{c}{ SAFRAS } \\
\hline & $1998 / 1999$ & $1999 / 2000$ & $2000 / 01$ & $2001 / 02$ & $2002 / 03$ & $2003 / 04$ \\
AÇÚCAR (t) & 17.960 .000 & 19.000 .000 & 16.185 .217 & 19.090 .744 & 22.434 .285 & 24.945 .018 \\
Centro/Sul & 15.180 .000 & 16.900 .000 & 12.642 .008 & 15.949 .950 & 18.601 .368 & 20.439 .702 \\
Norte/Nordeste & 2.780 .000 & 2.100 .000 & 3.543 .209 & 3.140 .794 & 3.832 .917 & 4.505 .316 \\
Evolução \% & 100 & 106 & 90 & 106 & 125 & 139 \\
ALCOOL (m3) & 13.912 .000 & 12.780 .000 & 10.572 .069 & 11.492 .579 & 12.594 .797 & 14.764 .086 \\
Centro/Sul & 12.281 .000 & 11.634 .000 & 9.076 .019 & 10.156 .994 & 11.154 .068 & 13.024 .018 \\
Norte/Nordeste & 1.631 .000 & 1.146 .000 & 1.496 .050 & 1.335 .585 & 1.440 .729 & 1.740 .068 \\
Evoluçăo\% & 100 & 92 & 76 & 83 & 91 & 106 \\
\hline
\end{tabular}

Fonte: UNICA (Centro/Sul), 2004; DATAGRO (Norte/Nordeste), 2004.

A Tabela 6 revela que o estado de São Paulo é o principal produtor de álcool do Brasil, sendo responsável pela produção de 8,8 milhões de metros cúbicos dos 13 milhões da região Centro-Sul e dos 14,1 milhões da produção brasileira. 
Tabela 6. Produção de álcool no Brasil nas safras 1999/2000, 2000/01, 2001/02, 2002/03 e 2003/04, por região, expressa em metros cúbicos

\begin{tabular}{|c|c|c|c|c|c|}
\hline ESTADOS/SAFRAS & $1999 / 2000$ & $2000 / 01$ & $2001 / 02$ & $2002 / 03$ & $2003 / 04$ \\
\hline ACRE & 0 & 0 & 0 & 0 & 0 \\
\hline RONDONIA & 0 & 0 & 0 & 0 & 0 \\
\hline AMAZONAS & 0 & 3.854 & 2.666 & 3.889 & 4.375 \\
\hline PARÁ & 25.504 & 31.273 & 24.993 & 26.426 & 35.012 \\
\hline TOCANTINS & 0 & 0 & 0 & 0 & 0 \\
\hline MARANHÃO & 57.174 & 46.944 & 75.097 & 83.579 & 95.474 \\
\hline PIAUÍ & 15.440 & 16.624 & 18.676 & 22.831 & 22.373 \\
\hline CEARÁ & 2.435 & 783 & 1.186 & 976 & 317 \\
\hline R. G. NORTE & 68.558 & 93.809 & 79.865 & 99.015 & 62.217 \\
\hline PARAIBA & 201.593 & 218.322 & 226.606 & 240.367 & 144.030 \\
\hline PERNAMBUCO & 339.893 & 297.324 & 261.933 & 306.974 & 231.219 \\
\hline ALAGOAS & 550.514 & 712.634 & 562.286 & 567.868 & 401.136 \\
\hline SERGIPE & 46.839 & 58.620 & 52.024 & 61.325 & 44.765 \\
\hline BAHIA & 60.142 & 48.484 & 54.412 & 57.891 & 47.254 \\
\hline NORTE-NORDESTE (*) & 1.368 .092 & 1.528 .671 & 1.359 .744 & 1.471 .141 & 1.088 .172 \\
\hline MINAS GERAIS & 643.805 & 485.063 & 524.441 & 635.816 & 771.732 \\
\hline ESPIRITO SANTO & 126.219 & 150.663 & 131.020 & 202.559 & 183.959 \\
\hline RIO DE JANEIRO & 117.853 & 92.596 & 64.792 & 109.042 & 107.934 \\
\hline SĀO PAULO & 8.492 .368 & 6.439 .113 & 7.134 .529 & 7.690 .689 & 8.806 .942 \\
\hline PARANÁ & 1.043 .465 & 799.364 & 960.270 & 980.472 & 1.224 .010 \\
\hline SANTA CATARINA & 0 & 0 & 0 & 0 & 0 \\
\hline R. G. SUL & 0 & 0 & 5.306 & 6.411 & 6.045 \\
\hline MATO GROSSO & 544.197 & 464.357 & 580.127 & 653.919 & 792.169 \\
\hline MATO GROSSO DO SUL & 371.046 & 314.777 & 396.521 & 418.052 & 480.571 \\
\hline GOIÁS & 314.759 & 318.431 & 379.284 & 455.124 & 646.344 \\
\hline CENTRO-SUL & 11.653 .712 & 9.064 .364 & 10.176 .290 & 11.152 .084 & 13.019 .706 \\
\hline BRASIL & 13.021 .804 & 10.593.035 & 11.536 .034 & 12.623 .225 & 14.107.878 \\
\hline
\end{tabular}

Fonte: ÚNICA, 2004. (*) Os dados da Região N/NE na safra 2003/04, são referentes à posição de 01/01/2004.

O número de unidades industriais no Brasil apresentado na Tabela 7 coloca São Paulo como o estado que concentra seu maior número. A maioria das unidades já se apresenta como produtora de ambos os produtos: açúcar e 
álcool. A possibilidade de atuar nos dois mercados melhora a estabilidade do negócio nessas unidades.

Tabela 7. Número de unidades industriais na safra 2003/04

\begin{tabular}{lcccccc}
\hline UNIDADES INDUSTRIAIS & SÃO PAULO & CENTRO SUL & NORTE NORDESTE & TOTAL & $\%$ do TOTAL \\
\hline Açúcar & 2 & 6 & 15 & 21 & 6,4 \\
Alcool & 22 & 62 & 36 & 98 & 29,8 \\
Açúcar+Álcool & 109 & 158 & 52 & 210 & 63,8 \\
& & & & 103 & 329 & 100,00 \\
\hline
\end{tabular}

Fonte: ORPLANA, 2004.

A Tabela 8 apresenta a lista ordenada dos 20 paises maiores importadores de açúcar do Brasil no ano de 2003. O Brasil exportou açúcar para 98 países num total aproximado de 13 milhões de toneladas e um faturamento, de 2,14 bilhões de dólares americanos. Dentre os 20 principais compradores, a Rússia é o mais importante com aproximadamente 3,84 milhões de toneladas, enquanto a Nova Zelândia é o vigésimo, com aproximadamente $130 \mathrm{mil}$ toneladas.

No ordenamento das exportação, o Brasil é o grande produtor e exportador de açúcar, conquistando mercado nos principais paises consumidores da Europa e da Ásia e Oriente Médio. Porém, ainda exporta uma quantidade menos expressiva para os Estados Unidos, o maior consumidor mundial de produtos. Já a China, o maior potencial emergente da atualidade, ainda tem pouca expressão para o mercado exportador brasileiro, estando em $75^{\circ}$ lugar, com apenas duas mil toneladas em 2003. 
Tabela 8. 20 paises maiores importadores de açúcar do Brasil no ano de 2003 e respectivas quantidades importadas, expressas em toneladas e em dólares dos EUA

\begin{tabular}{clcc}
\hline POSIÇĀO & \multicolumn{2}{r}{ PAIS DE DESTINO } & \multicolumn{2}{c}{ JANEIRO A } & $\begin{array}{c}\text { DEZEMBRO / } 2003 \\
\text { US } \$ \text { FOB }\end{array}$ \\
\hline 1 & RUSSIA, FED. DA & 3.841 .524 & 597.715 .190 \\
2 & EMIR. ARABES UNIDOS & 979.825 & 152.323 .196 \\
3 & NIGÉRIA & 820.975 & 144.090 .629 \\
4 & CANADA & 763.550 & 118.089 .712 \\
5 & SENEGAL & 734.839 & 115.688 .307 \\
6 & ARGÉLIA & 519.693 & 85.023 .382 \\
7 & EGITO & 515.130 & 87.230 .552 \\
8 & MARROCOS & 513.589 & 82.734 .379 \\
9 & ARABIA SAUDITA & 339.601 & 51.153 .641 \\
10 & GANA & 320.849 & 56.816 .521 \\
11 & IEMEM & 251.050 & 41.414 .442 \\
12 & ANGOLA & 196.217 & 35.907 .258 \\
13 & ROMENIA & 191.155 & 31.545 .946 \\
14 & ESTADOS UNIDOS & 181.300 & 72.738 .307 \\
15 & GEORGIA & 171.337 & 29.743 .404 \\
16 & BULGARIA & 170.212 & 26.196 .153 \\
17 & SIRIA, REP. ARABE & 162.017 & 28.077 .869 \\
18 & MAURITANIA & 159.033 & 27.558 .802 \\
19 & SOMALIA & 131.550 & 21.685 .350 \\
20 & NOVA ZELANDIA & 127.216 & 21.240 .114 \\
98 & & 12.914 .468 & 2.140 .002 .217 \\
\hline
\end{tabular}

Fonte: UNICA, 2004.

\subsection{Estabelecimento de Piracicaba como município canavicultor}

\subsubsection{Evolução da cultura no município}

Piracicaba é uma região tradicionalmente produtora de cana-de-açúcar. Desde o início de sua colonização, está ligada à cana-de-açúcar. Mesmo coexistindo com outras culturas também de importância econômica e social, a cultura da cana-de-açúcar sobreviveu ao café, ao chá e ao algodão. 
Conforme Torres (1975), alguns relatos demonstram que a estrutura fundiária do município de Piracicaba, desde sua fundação, tem ligação com a cana-de-açúcar. É um relato importante para subsidiar discussões sobre questões pertinentes à importância da cultura da cana-de-açúcar neste município.

Os documentos históricos com dados centenários transcritos pelo autor valem para confirmar a força desenvolvimentista que a cana-de-açúcar proporcionou à Piracicaba. Contabilizavam as terras, os engenhos, os produtores, a produção de cana e de açúcar entre outros parâmetros. Desde o século XVIII a cana-de-açúcar aparece em censos oficiais e documentos da câmara municipal, escritos em português arcaico, que respondiam a questionamentos do alto escalão do Império e do Reino de Portugal.

Piracicaba teve suas bases fundiárias nas sesmarias e, ao longo dos anos, a divisão destas áreas foi acontecendo baseada nas leis da época, as quais eram as mesmas do Reino de Portugal e ordenações do Império. Com o tombamento de 1817-1818, nota-se um certo fracionamento da propriedade em lotes menores em relação ás sesmarias. Algumas propriedades já estavam partilhadas em áreas menores, porém, ainda permaneciam algumas com 1.032, $1.200,3.375,4.050$ e 7.200 alqueires, também algumas áreas com tamanhos grandiosos, como as que ultrapassavam 20 mil alqueires e eram exploradas por vários fazendeiros. Mesmo assim, a cada indivíduo caberia grandes lotes de terras para a exploração agrícola. A partir de 1822, quando Piracicaba passa à condição de Vila, alega-se ser sua economia essencialmente açucareira e com bom número de engenhos e fábricas de açúcar, além de terras extremamente férteis, sendo a lavoura da cana a principal atividade econômica (Torres, 1975).

De acordo com os Oficios Diversos da Vila de Constituição, no ano de 1825, havia 53 fábricas de açúcar com alambique assentado, o que seria nos dias de hoje uma destilaria anexa. Neste mesmo ano foram produzidas 64.396 arrobas de açúcar, o que corresponde a $965.940 \mathrm{Kg}$. Por meio destas informações, observa-se que Piracicaba é tradicionalmente produtora de cana- 
de-açúcar, açúcar e álcool e este perfil agroindustrial sucroalcooleiro vem se configurando desde tempos mais remotos.

Torres (1975) descreve a divisão das propriedades no município, citando um recenseamento realizado em 1836, no qual confirma-se que nessa época não há mais terras devolutas e já existem 78 engenhos. As propriedades existentes delinearão o panorama rural do município, na época nitidamente açucareiro. Significava que não havia mais tantas propriedades de grande porte, ou seja, latifúndios, e que as grandes áreas já haviam sido divididas em áreas menores para os herdeiros ou quaisquer outros de posse. Características que nos dias de hoje podem atingir pequenas frações de terras chegando a inviabilizar a produção agrícola e principalmente a produção de cana-de-açúcar.

Os relatos da Câmara Municipal de do ano de 1854, quando Piracicaba ainda era denominada de Vila Nova da Constituição, mostram que a produção agrícola era promissora, com ênfase para a produção de açúcar destacando o funcionamento de 49 engenhos mais notáveis que já ultrapassavam 6 toneladas de produção anual. Além de diversos outros com produção menor e estando a maioria deles em bom estado, como seguem alguns trechos originais do Ofício da Câmara Municipal ao Exmo. Sr. Presidente da Província de São Paulo, de 25 de janeiro de 1854 :

"Exmo. Sr. A Câmara Municipal da Vila Nova da Constituição, cumprindo (...) informa a Vossa Excelência o seguinte: Nenhuma indústria de mineração se tem apresentação em seu município, nem talvez se apresentará, porque não consta que neste Municipio exista mineral algum ao menos não tem ainda sido descoberto e nem explorado, entregues os habitantes deste Município à lavoura (...) o mesmo se dá a respeito à indústria fabril propriamente dita (...) salvo se por indústria fabril se considerar os estabelecimentos de açúcar, café e chá, os aparelhos ou máquinas destinadas a preparar esses produtos para levar ao mercado. Como porém isto faz parte da lavoura, tendo esta Câmara de tratar da indústria agrícola segundo Vossa Excelência exige então mencionará o que há. Três são os produtos agricolas que mais prosperam nesta Vila e são o açúcar, o café e o chá, e na inclusa relação compreende a Câmara os mais importantes, 
seu rendimento aproximado, assim como também faz menção de alguns outros produtos que desta Vila se exporta (...) Alguns estabelecimentos de açúcar terão diminuído na produção, outros porém terão aumentado, mas nem isto nem aquilo é coisa sensivel, nem isto nem aquilo traz outra origem senão a bondade das terras, melhor aproveitamento. (...)" (Torres, 1975).

Com o advento dos Engenhos Centrais passa a existir um elemento de transição entre os bangüês e as usinas (Vargas, 1976). A partir de 1875 o Governo Imperial incentiva a modernização da indústria açucareira e em 1877 ocorre a fundação o primeiro Engenho Central do Brasil, em Quissamã - RJ (Leão, 2002). Logo em seguida outros engenhos foram construidos, quando em 1881 foi fundado o Engenho Central de Piracicaba pelo Dr. Esteves Ribeiro de Souza, o Barão de Rezende, entre outros acionistas, funcionando até 1974. Com a fundação desses engenhos, inaugurava-se uma nova era do setor sucroalcooleiro, com a concentração de produção em poucas e grandes unidades industriais demandando avanços tecnológicos para manter a liderança dessas unidades. Esta havia sido uma experiência bem sucedida no Egito, nas Índias Ocidentais Francesas, nas Ilhas da Martinica e Guadalupe (Leão, 2002).

Segundo Bilac \& Terci (2001), dados apresentados pela Gazeta de Piracicaba em 1905, o município não era um centro importante de produção de café, porém apresenta sua imagem de modernidade sobre outras regiões de produção agrícola, para colocar-se ao lado dos grandes centros produtores. Utilizou-se da imprensa e projetou-se em âmbito nacional como um município policultor, onde predominava a pequena propriedade, progressista e economicamente equilibrada. Além de milho, feijão, arroz, algodão, produzidos pelos pequenos produtores rurais em grande número e café por médios e grandes produtores, num total de 165, a cana-de-açúcar mantinha-se como uma cultura de grande importância, com produção de 347.162 arrobas de açúcar. Destas, 281.784 arrobas eram provenientes do Engenho Central, 57.988 arrobas do Engenho Central de Monte Alegre e 7.390 arrobas por outros 
28 engenhos menores, além de 1.413 pipas de aguardente produzidas por 63 engenhos.

A eclosão da segunda guerra mundial teve impacto nos dois principais produtos da agroindústria canavieira, o açúcar e o álcool. Nesta época, com a escassez de petróleo, a produção de álcool anidro passa a ser considerada estratégica na economia nacional. Com o pós-guerra persistiu a tendência de expansão da produção de cana-de-açúcar, açúcar e álcool na região CentroSul, favorecida por problemas que o Nordeste enfrentava, como as dificuldades de transporte do Recife para o Rio de Janeiro e Santos, aliadas a defasagem entre o consumo e produção daquela região (Moraes, 2000). Piracicaba encaixa-se neste contexto e segundo Mourão (2001), no início do século XX o município continuava tendo como base da economia a agricultura, com destaque para o café e cana-de-açúcar. Piracicaba chegava na década de 1950 com um complexo agroindustrial desenvolvido e passa a ser conhecida como " $\mathrm{A}$ Capital do Açúcar". Entre outros cita a importância da cana-de-açúcar como força influenciadora na formação socioeconômica e cultural da região, onde por mais de duzentos anos a história de Piracicaba está ligada à cana-de-açúcar, conferindo um perfil peculiar ao município. Para a produção de açúcar e álcool, a partir da implantação do Pró-álcool na década de 1970, as plantações de cana foram intensificadas e as áreas com a cultura aumentadas, reforçando o perfil canavieiro de Piracicaba.

Nota-se pelos antecedentes históricos que o município de Piracicaba teve como seu principal fator de desenvolvimento a agricultura e nela se destacou a produção de cana-de-açúcar. Com o passar do tempo desenvolveuse num dos mais importantes pólos tecnológicos do setor sucroalcooleiro, seja na tecnologia da produção de cana e sua transformação, ou na indústria metalmecânica, fábricas de acessórios voltadas para a confecção de equipamentos e plantas industriais de processamento da cana em açúcar e álcool. 


\subsubsection{Características do cultivo de cana-de-açúcar no município}

A cana-de-açúcar é a cultura mais importante para o município de Piracicaba, pois ocupa quase metade da sua área cultivada totalizando aproximadamente 46 mil ha na safra 2004/2005 emprega a maior parte da mãode-obra rural (Sparovek \& Lepsch, 1995; ORPLANA, 1996). A importância desse sub-setor de atividade econômica é, como se pode aquilatar pelos dados descritos, bastante expressiva. Seus movimentos, portanto, causam impactos de significância na economia agrícola paulista, rebatendo na geração de renda bruta, no emprego rural e no nível tecnológico (Veiga Filho, 1999).

Até a presente data, parte significativa do corte é feito manualmente em áreas previamente queimadas, para reduzir a quantidade de palha e facilita a operação. As recentes regulamentações ambientais restringem gradualmente o uso da queima da palha como facilitador do corte manual, obrigando a adoção de colheita mecanizada. A colheita de cana-de-açúcar sem queima prévia apresenta diversas vantagens como proteção do solo contra a erosão pela palha, redução da interferência das plantas daninhas, possibilidade de redução do número de terraços, supressão do cultivo mecânico nas soqueiras e menor compactação do solo e dano às soqueiras no caso de corte mecanizado associado a transbordo. Por outro lado, a colheita mecanizada sofre restrições técnicas e implica em modificação do sistema produtivo e em investimentos. Há necessidade de realizar a sulcação com paralelismo perfeito e com pouca sinuosidade, eliminar linhas mortas e terraços no talhão, aumentar o comprimento dos talhões, construir carreadores em nivel acompanhando paralelamente a sulcação, sem, no entanto comprometer a conservação do solo. Adicionalmente as colhedoras apresentam dificuldades para operar em área com declividade superior a 12\% (Barbosa, 1997; Furlani Neto, 1997; Sparovek et al., 1996; Silva, 1997).

Segundo Gonçalves \& Souza (1998b), a mudança para a colheita mecanizada de toda a cana do Estado de São Paulo implicará no desemprego 
de 86,5 a 230 mil trabalhadores e criará impactos diretos sobre os pequenos e médios produtores do Estado de São Paulo, que segundo dados da ORPLANA (2003) dos somam mais de 12 mil Fornecedores, dos quais $92 \%$ têm áreas de produção inferiores a 125 há.

Mourão (2001), apresenta ainda uma síntese dos pontos fortes, pontos fracos, ameaças e oportunidades para o desenvolvimento do município de Piracicaba, com inclusão da cana-de-açúcar. Como ponto forte cita a grande área agrícola do município, com boas terras, forte agricultura canavieira e importante setor sucroalcooleiro; uma malha rodoviária ligando Piracicaba aos principais pontos do Brasil, o que significa facilidade de escoamento de produção e diminuição de custos, conferindo competitividade. Por outro lado entre os pontos fracos do município está a topografia, cujo relevo acidentado dificulta a mecanização e a competitividade da agricultura canavieira nestes locais. No item ameaças, a não manutenção do Pró-álcool afetaria a economia do município e o crescimento da ocupação desordenada das áreas rurais pelos loteamentos irregulares e inadequados. Como oportunidades, o autor cita o turismo rural, além de novas atividades na área rural, referindo-se à diversificação de culturas.

\subsection{Importância dos Fornecedores na produção de cana-de-açúcar}

\subsubsection{Fornecedores de cana do Brasil}

Segundo dados da ORPLANA (2004), os produtores independentes, ou seja, os Fornecedores de cana, são responsáveis por aproximadamente $27 \%$ da produção de cana do Brasil (358.792 milhões de toneladas na safra 2003/4 Tabela 3). Os Fornecedores do Estado de São Paulo contribuem com $67 \%$ da produção total dos produtores independentes e $14,5 \%$ do total produzido no País. O segundo maior Estado em produção de cana de produtores 
independentes é o de Pernambuco, com $8,4 \%$ da produção total desta categoria e $3,3 \%$ do total produzido no Brasil.

\subsubsection{Fornecedores de cana do Estado de São Paulo}

No Estado de São Paulo os Fornecedores de cana somaram na safra 2003/04 o total de 12.655 (Tabela 9), já na safra 2004/05 foram 13110 (Tabela 14 representados pela Organização de Plantadores de Cana da Região CentroSul do Brasil - ORPLANA.

Para o perfil do Fornecedor de cana do Estado de São Paulo, na safra 2003/04, considerou-se apenas os dados apurados no Sistema de Pagamento de Cana pela Qualidade - Sistema CONSECANA (Conselho dos Produtores de Cana-de-Açúcar, Açúcar e Álcool do Estado de São Paulo). A cana entregue pelos Fornecedores foi de aproximadamente $25 \%$ de toda matéria-prima processada na safra 2003/4, correspondendo a aproximadamente 52 milhões de toneladas e equivalendo a 7,73 milhões de toneladas de ATR (Açúcar Total Recuperável). Deste total, foi produzido o equivalente a 3,83 milhões de toneladas de açúcar e 2,07 bilhão de litros de álcool carburante, para um "mix" de produção de $51,6 \%$ para açúcar, 31,5\% para álcool anidro e 15,9\% para hidratado (ORPLANA, 2004).

Quando comparada aos principais complexos agro-industriais paulistas, a agroindústria da cana-de-açúcar só seria inferior, em termos de renda, à somatória do complexo protéico animal (pecuária, avícola e suíno) e, mesmo assim, em índices muito próximos, gerando uma renda maior que o dobro da soma dos grãos, maior que o triplo dos sucos cítricos e olerícolas, constituindose, portanto, na mais importante cultura do ponto de vista de geração de renda e, conseqüentemente, de arrecadação de impostos para os cofres públicos, estadual e federal (ORPLANA, 2004).

Foram recolhidos aos cofres públicos cerca de 50 milhões de reais, para o governo federal, referentes ao Funrural (ORPLANA,2004). 
A Tabela 9 apresenta a estratificação da produção de cana-de-açúcar dos Fornecedores, demonstrando que $92 \%$ dos Fornecedores produzem até 10 mil toneladas de cana. A ORPLANA considera uma produtividade agrícola media de aproximadamente 80 tha, o que significa que a maioria destes Fornecedores produz em áreas de até 125 ha e entregaram $42 \%$ da produção, enquanto que, apenas $8 \%$ dos produtores plantam em áreas maiores $\mathrm{e}$ entregaram $58 \%$ da produção.

Tabela 9. Estratificação da produção de cana-de-açúcar em número de Fornecedores e em toneladas, para o Estado de São Paulo

\begin{tabular}{cccccc}
\hline $\begin{array}{c}\text { ESTRATO DE } \\
\text { PRODUÇÃO(t) }\end{array}$ & $\begin{array}{c}\text { Número de } \\
\text { Fornecedores }\end{array}$ & $\begin{array}{c}\% \text { de } \\
\text { Fornecedores }\end{array}$ & $\begin{array}{c}\text { ÁREA } \\
\text { ha }\end{array}$ & $\begin{array}{c}\text { Produção } \\
(\mathbf{t})\end{array}$ & $\begin{array}{c}\% \text { da } \\
\text { Produção }\end{array}$ \\
\hline$<200$ & 1.315 & 10,4 & 1 & 154.608 & 0,3 \\
$201-800$ & 3.524 & 27,9 & 6 & 1.638 .542 & 3,1 \\
$801-4.000$ & 5.189 & 41,0 & 24 & 9.791 .712 & 18,9 \\
$4.000-10.000$ & 1.610 & 12,7 & 78 & 10.108 .432 & 19,5 \\
$>10.000$ & 1.017 & 8,0 & 366 & 30.205 .705 & 58,2 \\
TOTAL & $\mathbf{1 2 . 6 5 5}$ & $\mathbf{1 0 0 , 0}$ & $\mathbf{5 0}$ & $\mathbf{5 1 . 8 9 8 . 9 9 9}$ & $\mathbf{1 0 0 , 0}$ \\
\hline
\end{tabular}

Fonte: ORPLANA, 2004.

A área média de produção de cana, ainda conforme a Tabela 9, é de 50 ha, sendo que as áreas variam de 26 a 111 hectares nas diferentes regiões produtoras de cana do Estado de São Paulo. Isto permite afirmar que o setor da agroindústria da cana-de-açúcar ainda apresenta uma grande distribuição da renda, ao contrário de outras culturas, demonstrando, assim, a importância do pequeno e do médio produtor de cana que, ao todo, conforme Tabela 10, cultiva cerca de 760.000 hectares de terra, com uma produtividade média de 82 t/ha na safra 2003/04. 
Tabela 10. Área cultivada pelos Fornecedores de cana do estado de São Paulo

\begin{tabular}{cc}
\hline FASE & AREA (ha) \\
\hline Colheita & 633.000 \\
Plantio & 127.000 \\
Total & 760.000 \\
Produtividade Média (t/ha) & 82 \\
\hline
\end{tabular}

Fonte: ORPLANA, 2004.

A Tabela 11 mostra as regiões produtoras de cana-de-açúcar no Estado de São Paulo classificadas pela ORPLANA (2004), as quais englobam várias associações. A região de Piracicaba destaca-se por ser a maior em número de Fornecedores e a segunda em produção de cana, representando $41,6 \%$ do total de Fornecedores.

Tabela 11. Distribuição da produção por região denominada pela ORPLANA

\begin{tabular}{cccccc}
\hline REGIÃO & $\begin{array}{c}\text { Número de } \\
\text { Fornecedores }\end{array}$ & $\begin{array}{c}\text { \% de } \\
\text { Fornecedores }\end{array}$ & $\begin{array}{c}\text { ÁREA } \\
\text { Corte (ha) }\end{array}$ & $\begin{array}{c}\text { Produção } \\
(t)\end{array}$ & $\begin{array}{c}\% \text { da } \\
\text { Produção }\end{array}$ \\
\hline Araraquara & 611 & 4,8 & 37 & 1.829 .203 & 3,5 \\
Arenito & 866 & 6,8 & 107 & 7.574 .295 & 14,6 \\
Jaú & 2.080 & 16,4 & 50 & 8.673 .628 & 16,7 \\
Piracicaba & 5.262 & 41,6 & 26 & 10.746 .363 & 20,7 \\
Ribeirão Preto & 3.529 & 27,9 & 70 & 20.178 .903 & 38,8 \\
Assis & 307 & 2,5 & 111 & 2.896 .607 & 5,7 \\
TOTAL & $\mathbf{1 2 . 6 5 5}$ & $\mathbf{1 0 0 , 0}$ & $\mathbf{5 0}$ & $\mathbf{5 1 . 8 9 8 . 9 9 9}$ & $\mathbf{1 0 0 , 0}$ \\
\hline
\end{tabular}

Fonte: ORPLANA, 2004.

A Tabela 12 apresenta o preço médio do kg de Açúcar Total Recuperável - ATR pago aos Fornecedores. Este varia de $\mathrm{R} \$ 0,1967$ na Associação de Ourinhos a $R \$ 0,2091$ na Associação de Assis, representando o valor médio de $\mathrm{R} \$ 0,2037$ pago pelas 78 unidades industriais do Estado de São Paulo que participam do Sistema CONSECANA. 
Tabela 12. Resultados da qualidade tecnológica da cana e financeiros na safra 2003/04 por associação de Fornecedores, filiadas à ORPLANA

\begin{tabular}{lcccc}
\hline \multicolumn{1}{c}{ ASSOCIAÇÃO } & Cana Entregue (t) & Kg de ATR por tonelada (média) & $\begin{array}{c}\text { R\$ por kg de ATR } \\
\text { (média) }\end{array}$ & $\begin{array}{c}\text { VTC R\$/t } \\
\text { (média) }\end{array}$ \\
\hline Araraquara & 1.829 .203 & 151,17 & 0,2032 & 30,73 \\
Assis & 2.457 .522 & 141,14 & 0,2091 & 29,51 \\
Barra Bonita & 1.350 .488 & 148,19 & 0,2037 & 30,17 \\
Bebedouro & 1.474 .300 & 152,86 & 0,2040 & 31,18 \\
Capivari & 2.050 .489 & 146,04 & 0,2026 & 29,59 \\
Catanduva & 4.030 .403 & 150,87 & 0,2048 & 30,90 \\
Chavantes & 186.408 & 141,87 & 0,2037 & 30,17 \\
General Salgado & 283.160 & 156,46 & 0,2030 & 31,76 \\
Guariba & 5.330 .931 & 149,59 & 0,2021 & 30,30 \\
Igarapava & 781.723 & 151,89 & 0,2037 & 30,17 \\
Jaú & 2.736 .183 & 150,76 & 0,2034 & 30,70 \\
L. Paulista & 4.586 .957 & 147,93 & 0,2017 & 30,11 \\
Monte Aprazivel & 1.410 .788 & 153,80 & 0,2037 & 31,33 \\
Novo Horizonte & 1.115 .647 & 148,39 & 0,2046 & 30,48 \\
Orindiuva & 734.296 & 155,31 & 0,2012 & 31,25 \\
Ourinhos & 252.676 & 142,03 & 0,1967 & 28,97 \\
Piracicaba & 7.743 .495 & 147,88 & 0,2058 & 30,49 \\
Porto Feliz & 532.333 & 148,93 & 0,2034 & 30,30 \\
Sta. Bárbara & 420.047 & 151,07 & 0,2074 & 31,66 \\
Sertãozinho & 12.591 .950 & 148,85 & 0,2061 & 30,68 \\
TOTAL & 51.898 .999 & 148,89 & 0,2037 & 30,39 \\
\hline
\end{tabular}

Fonte: ORPLANA, 2004.

A qualidade da matéria-prima expressa em $\mathrm{kg}$ de ATR por tonelada de cana-de-açúcar, oscilou entre $141,14 \mathrm{~kg}$, em Assis, a 156,46 kg, em General Salgado, com uma média de $148,89 \mathrm{~kg} / \mathrm{t}$, num total de 7,73 milhões de toneladas de ATR.

Desta forma, o valor da tonelada de cana-de-açúcar variou entre $R \$$ 28,97 na Associação de Fornecedores de Cana de Ourinhos e R\$31,76, na Associação dos Fornecedores de Cana de General Salgado, fechando em R\$ 30,22 como média geral do Estado de São Paulo e em $R \$ 30,39$ nas 78 
unidades industriais que processaram cana dos Fornecedores filiados à ORPLANA, valor realmente pago na safra em 20/03/04.

As Tabelas 13 e 14 revelam que os Fornecedores estão organizados em 21 associações de classe filiadas à ORPLANA. A Associação dos Fornecedores de Cana de Piracicaba - AFOCAPI é a que possui maior número de associados, 3.960 na safra 2003/04 e 4007 na safra 2004/05. Estes representam aproximadamente $31 \%$ do total de Fornecedores do Estado de São Paulo, com uma área média de 25 hectares e a segunda maior produção de cana. Na safra $2004 / 5$, conforme mostra a Tabela 14 , o total de cana foi de 7,940 milhões de toneladas, significando $13,4 \%$ da produção de Fornecedores do Estado de São Paulo. A Associação de Sertãozinho - CANAOESTE é a segunda maior em número de Fornecedores, com 1.998 associados, representando $15,3 \%$ do total, com uma área média de 80 hectares. É a primeira em produção com aproximadamente 13,6 milhões de toneladas representando $22,9 \%$, da produção.

Tomando-se como base a safra 2003/4, a produção de cana dos produtores independentes do Estado de São Paulo iguala-se à do México e supera a da Austrália, paises estes que estão entre os maiores produtores mundiais (ORPLANA, 2004). Neste mesmo ano a produção desses Fornecedores correspondeu a 25\% (52 milhões de toneladas) do total (207 milhões). 
Tabela 13. Distribuição da produção por associação de Fornecedores associada a ORPLANA

\begin{tabular}{cccccc}
\hline ASSOCIAÇÃO & $\begin{array}{c}\text { NÚMERO DE } \\
\text { Fornecedores }\end{array}$ & $\begin{array}{c}\text { ÁREA } \\
\text { ha }\end{array}$ & PRODUÇÃO $(\mathrm{t})$ & \% DA ORPLANA & \% DE SÃO PAULO \\
\hline Araraquara & 611 & 37 & 1.829 .203 & 3,5 & 0,9 \\
Assis & 239 & 121 & 2.457 .522 & 4,7 & 1,2 \\
Barra Bonita & 558 & 28 & 1.350 .488 & 2,6 & 0,6 \\
Bebedouro & 416 & 42 & 1.474 .300 & 2,8 & 0,7 \\
Capivari & 902 & 28 & 2.050 .489 & 3,9 & 1,0 \\
Catanduva & 410 & 120 & 4.030 .403 & 7,8 & 1,9 \\
Chavantes & 34 & 70 & 186.408 & 0,4 & 0,1 \\
General Salgado & 35 & 100 & 283.160 & 0,6 & 0,1 \\
Guariba & 836 & 75 & 5.330 .931 & 10,3 & 2,6 \\
Igarapava & 317 & 31 & 781.723 & 1,5 & 0,4 \\
Jaú & 956 & 35 & 2.736 .183 & 5,3 & 1,3 \\
L. Paulista & 566 & 98 & 4.586 .957 & 8,8 & 2,2 \\
M. Aprazivel & 209 & 79 & 1.410 .788 & 2,7 & 0,7 \\
N. Horizonte & 105 & 130 & 1.115 .647 & 2,2 & 0,5 \\
Orindiuva & 107 & 83 & 734.296 & 1,4 & 0,4 \\
Ourinhos & 34 & 87 & 252.676 & 0,5 & 0,1 \\
Piracicaba & $\mathbf{3 . 9 6 0}$ & $\mathbf{2 5}$ & $\mathbf{7 . 7 4 3 . 4 9 5}$ & $\mathbf{1 4 , 9}$ & $\mathbf{3 , 7}$ \\
Porto Feliz & 189 & 35 & 532.333 & 1,0 & 0,3 \\
Sta. Bárbara & 211 & 25 & $\mathbf{4 2 0 . 0 4 7}$ & 0,8 & 0,2 \\
Sertãozinho & 1.960 & 80 & 12.591 .950 & 24,3 & 6,1 \\
ORPLANA & $\mathbf{1 2 . 6 5 5}$ & $\mathbf{5 0}$ & $\mathbf{5 1 . 8 9 8 . 9 9 9}$ & $\mathbf{1 0 0 , 0}$ & $\mathbf{2 5 , 0}$ \\
SÃO PAULO & & & $\mathbf{2 0 7 . 5 7 2 . 5 3 5}$ & & $\mathbf{1 0 0 , 0}$ \\
\hline
\end{tabular}

Fonte: ORPLANA, 2004.

Houve amento de 47 Fornecedores na AFOCAPI da safra 2003/04 para a safra 2004/05. 
Tabela 14. Resultados Tecnológicos da safra 2004/05 por associação de Fornecedores, ligadas à ORPLANA

\begin{tabular}{|c|c|c|c|c|c|c|c|c|c|}
\hline ASSOCIAÇÃO & $\begin{array}{c}\mathrm{N}^{0} \\
\text { Fornec }\end{array}$ & $\begin{array}{c}\text { CANA (t) } \\
\text { ENTREGUE }\end{array}$ & $\%$ & PZA & FIBRA & $\mathrm{PC}$ & ARC & ATR & $\begin{array}{l}\text { ATR } \\
F(k)\end{array}$ \\
\hline Andradina & 17 & 397.883 & 68,75 & 85,30 & 12,78 & 14,96 & 0,60 & 143,86 & 138,47 \\
\hline Araraquara & 752 & 2.526 .782 & 52,62 & 87,88 & 12,81 & 15,30 & 0,52 & 146,37 & 146,02 \\
\hline Assis & 273 & 2.725 .217 & 43,22 & 88,10 & 12,12 & 14,48 & 0,52 & 138,78 & 138,76 \\
\hline Barra Bonita & 368 & 833.275 & 69,63 & 88,18 & 12,65 & 15,26 & 0,52 & 145,89 & 145,54 \\
\hline Bebedouro & 318 & 965.650 & 52,97 & 85,88 & 12,60 & 15,10 & 0,58 & 144,97 & 144,97 \\
\hline Capivari & 1418 & 2.219 .081 & 54,44 & 87,74 & 12,29 & 14,54 & 0,53 & 139,37 & 138,93 \\
\hline Catanduva & 504 & 5.725 .662 & 68,66 & 87,27 & 12,74 & 15,36 & 0,54 & 147,06 & 147,06 \\
\hline Chavantes & 37 & 189.157 & 59,27 & 86,83 & 13,15 & 14,83 & 0,55 & 142,19 & 141,46 \\
\hline General Salgado & 38 & 276.369 & 33,46 & 87,18 & 13,20 & 14,97 & 0,54 & 143,43 & 141,81 \\
\hline Guariba & 832 & 5.740 .471 & 43,98 & 88,61 & 12,29 & 15,18 & 0,51 & 145,06 & 145,06 \\
\hline Igarapava & 388 & 1.029 .336 & 64,93 & 87,69 & 12,73 & 15,26 & 0,53 & 145,99 & 145,66 \\
\hline Jaú & 714 & 2.656 .640 & 45,21 & 87,68 & 12,31 & 15,45 & 0,53 & 147,84 & 147,65 \\
\hline Lençóis Paulista & 552 & 6.676 .466 & 26,84 & 87,94 & 11,82 & 15,09 & 0,53 & 144,41 & 143,58 \\
\hline Monte Aprazivel & 222 & 2.314 .751 & 58,09 & 87,86 & 11,97 & 15,67 & 0,53 & 149,82 & 149,02 \\
\hline Novo Horizonte & 128 & 1.400 .072 & 64,21 & 89,03 & 12,82 & 15,01 & 0,49 & 143,37 & 143,37 \\
\hline Orindiuva & 109 & 878.954 & 64,69 & 87,69 & 12,39 & 15,83 & 0,53 & 151,35 & 151,35 \\
\hline Ourinhos & 33 & 308.959 & 86,56 & 88,56 & 12,06 & 14,59 & 0,51 & 139,60 & 139,60 \\
\hline Piracicaba & 4007 & 7.940 .050 & 61,44 & 87,24 & 12,25 & 14,73 & 0,55 & 141,23 & 141,05 \\
\hline Porto Feliz & 187 & 467.782 & 68,42 & 87,38 & 12,42 & 14,52 & 0,54 & 139,31 & 139,09 \\
\hline Santa Barbara & 215 & 416.658 & 57,44 & 88,41 & 11,76 & 15,13 & 0,52 & 144,67 & 144,15 \\
\hline Sertãozinho & 1998 & 13.553 .605 & 56,56 & 87,51 & 12,60 & 14,90 & 0,54 & 142,76 & 142,76 \\
\hline TOTAL & 13110 & 59.242 .819 & 53,32 & 87,70 & 12,39 & 15,03 & 0,53 & 143,95 & 143,70 \\
\hline
\end{tabular}

Fonte: ORPLANA, 2005.

Segundo a ORPLANA (2004), os Fornecedores que entregaram no mês de abril de 2004, a chamada safrinha, receberam o preço médio de $\mathrm{R} \$ 0,3138 / \mathrm{Kg}$ de ATR. Esta representou 456.287 toneladas de cana, com 116,55 $\mathrm{kg}$ de ATR por tonelada e os Fornecedores receberam $\mathrm{R} \$ 36,57$ por tonelada de cana, ou seja, a matéria-prima com uma quantidade de ATR $21,7 \%$ menor que a média da safra e um preço médio por $\mathrm{kg}$ de ATR $54 \%$ maior que o preço médio da safra. Assim, obteve-se preço $20,3 \%$ maior do que o preço médio da safra 2003/04. 
Conforme demonstram as Tabelas 12 e 14, a produção de cana dos Fornecedores do estado de São Paulo na safra 2004/05 superou a safra 2003/04 em aproximadamente 7,4 milhões de toneladas, representando acréscimo de $15,3 \%$. Já a quantidade média de ATR apurada foi menor, o que diminuiu a rentabilidade por tonelada de cana. Por outro lado, o VTC (valor por tonelada de cana) médio na safra $2003 / 04$ foi de $R \$ 30,39$, enquanto atingiu $\mathrm{R} \$ 35,14$ na safra $2004 / 05$. O valor médio foi de $R \$ 0,2445 / \mathrm{Kg}$ de $A T R$ e $143,89 \mathrm{Kg}$ de ATR por tonelada de cana, contra 148,89 $\mathrm{Kg}$ na safra 2003/04.

No caso dos Fornecedores da região de abrangência da AFOCAPI, na safra 2004/05 foram produzidas aproximadamente 196,6 mil toneladas de cana a mais que na safra $2003 / 04$, significando aproximadamente $2,54 \%$ de acréscimo.

O aumento da produção dos Fornecedores do estado deve-se à expansão principalmente na região Noroeste, onde áreas antes ocupadas com pastagens ou citricultura passaram a produzir cana-de-açúcar, à implantação de novas unidades industriais, o fato de que algumas unidades repassaram suas áreas de cana para os Fornecedores, a áreas de citricultura trocadas por cana, entre outros. A região de Piracicaba não teve um aumento de produção expressivo, comparando-se à produção média do estado de São Paulo, pelo fato de ser uma região que tem pouca possibilidade de expansão.

Considerando-se o "mix" de produção da safra 2003/04, a matéria prima entregue pelos Fornecedores representou uma produção equivalente em açúcar e álcool, apresentada na Tabela 15. 
Tabela 15. Produção equivalente de açúcar e álcool

\begin{tabular}{lc}
\hline \multicolumn{1}{c}{ PRODUTO DA CANA-DE-AÇÚCAR } & Produção Equivalente \\
\hline ATR - Açúcar Total Recuperável & $7.727 .000 \mathrm{t}$ \\
AÇÚCAR & $3.828 .600 \mathrm{t}$ \\
ÁLCOOL ANIDRO & $1.237 .600 \mathrm{~m} 3$ \\
ÁLCOOL HIDRATADO & $838.900 \mathrm{~m} 3$ \\
BAGAÇO & $14.250 .000 \mathrm{t}$ \\
\hline
\end{tabular}

Fonte: ORPLANA, 2004.

A Tabela 16 apresenta a estratificação geral dos Fornecedores de cana do Estado de São Paulo na safra 2004/05, demonstrando que a maior parte destes Fornecedores produz menos de 2.400 toneladas. Isto os confere a caracteristica de pequenos produtores.

Tabela 16. Estratificação geral dos Fornecedores de cana do Estado de São Paulo na safra 2004/05

\begin{tabular}{|c|c|c|}
\hline ESTRATO & $\mathrm{N}^{0}$ de Fornecedores & CANA ENTREGUE ( $t)$ \\
\hline Menor que $2400(t)$ & 8.964 & 7.666 .321 \\
\hline De 2.401 a $8.000(t)$ & 2.692 & 11.595 .457 \\
\hline De 8.001 a $16.000(t)$ & 794 & 8.709 .053 \\
\hline De 16.001 a $24.000(t)$ & 265 & 5.108 .311 \\
\hline De 24.001 a 32.000 (t) & 118 & 3.289 .957 \\
\hline De 32.001 a $40.000(t)$ & 68 & 2.422 .699 \\
\hline De 40.001 a $48.000(t)$ & 39 & 1.705 .059 \\
\hline De 48.001 a $56.000(t)$ & 39 & 2.001 .432 \\
\hline De 56.001 a $64.000(t)$ & 25 & 1.488 .800 \\
\hline De 64.001 a $72.000(t)$ & 20 & 1.354 .695 \\
\hline De 72.001 a $80.000(t)$ & 12 & 918.949 \\
\hline De 80.001 a $88.000(t)$ & 6 & 500.600 \\
\hline De 88.001 a $96.000(t)$ & 13 & 1.178 .890 \\
\hline De 96.001 a $104.000(t)$ & 6 & 601.934 \\
\hline De 104.001 a $112.000(t)$ & 6 & 642.813 \\
\hline De 112.001 a $120.000(t)$ & - & - \\
\hline De 120.001 a $128.000(t)$ & 3 & 374.643 \\
\hline De 128.001 a $136.000(t)$ & 2 & 265.844 \\
\hline Maior que $136.001(t)$ & 38 & 9.417 .361 \\
\hline TOTAL & 13.110 & 59.242 .818 \\
\hline
\end{tabular}

Fonte: ORPLANA, 2005. 
Com relação à força de trabalho, demonstrada na Tabela 17, a cana para a indústria contribui com 368,6 mil Equivalentes-Homem-Ano (EHA), ou seja, $46 \%$ do total da mão-de-obra empregada na agropecuária paulista. É a cultura que mais emprega trabalhadores não qualificados, gerando impactos sociais bastante expressivos do ponto de vista quantitativo. Provavelmente qualquer medida que interfira nas relações econômicas e sociais relativas ao complexo da agroindústria canavieira, poderá afetar toda a cadeia produtiva, o que significa, que as transformações, decorrentes da elevação dos custos de produção da cana-de-açúcar, poderão resultar em impactos significativos na geração de emprego e de renda (ORPLANA, 2003).

Tabela 17. Empregos diretos gerados nas diferentes fases da cultura de canade-açúcar no âmbito dos Fornecedores de cana do Estado de São Paulo

\begin{tabular}{ccc}
\hline FASES DA CULTURA & EMPREGOS & ÉPOCA \\
\hline Colheita & 58.000 & Junho a Novembro \\
Cultivo da Soqueira & 18.000 & Junho a Dezembro \\
Plantio de 12 meses & 5.000 & Outubro a Novembro \\
Plantio de 18 meses & 24.000 & Fevereiro a Abril \\
Cultivo pós - plantio & 5.300 & Maio a Junho. \\
Total & 110.300 & Fevereiro a Dezembro \\
\hline
\end{tabular}

Fonte: ORPLANA, 2004.

Com a desregulamentação do Setor Sucroalcooleiro pelo Governo Federal ocorre a formação de um conselho bipartite para a elaboração do modelo de autogestão. Assim, é fundado o Conselho dos Produtores de Canade-Açúcar, Açúcar e Álcool de São Paulo - CONSECANA, que passa a coordenar o relacionamento entre as partes (CONSECANA, 2004). Os Fornecedores de cana do estado de São Paulo estão representados neste conselho pela ORPLANA, a qual possui membros na diretoria do CONSECANA e na Câmara Técnica e Econômica - CANATEC. 


\subsubsection{Fornecedores de cana do município de Piracicaba}

\subsubsection{Os Fornecedores e as suas Entidades de Classe}

Os Fornecedores de cana do municipio de Piracicaba estão congregados em duas importantes Entidades: Associação dos Fornecedores de Cana de Piracicaba - AFOCAPI, que tem por finalidade a representação classista, a extensão rural, assistência técnica agronômica à produção de cana e suas implicações e assistência à saúde; e a Cooperativa dos Plantadores de Cana do Estado de São Paulo - COPLACANA, que tem seu foco na comercialização e fabricação de insumos, máquinas e implementos e também assistência técnica agronômica.

Com a necessidade de um trabalho mais direcionado para fortalecer a classe dos Fornecedores de Cana de Piracicaba e Região, fundou-se a AFOCAPI em 1947. Desde então, esta desempenha uma importante liderança em defesa da classe, reivindicando pelos seus direitos e assumindo os seus deveres, baseados no Estatuto da Lavoura Canavieira (Farhat, 2004).

Segundo Jungmann (1971), o Estatuto foi convertido em lei em 1941 estabelecendo o relacionamento entre os produtores independentes de cana, os industriais e o Estado, e inaugurando uma nova ordem no cenário canavieiro brasileiro. De acordo com Farhat (2004) a partir de 1983 tem início uma nova fase no setor sucroalcooleiro, com o novo sistema de Pagamento de Cana Pelo Teor de Sacarose - PCTS. Por este sistema a cana passa a ser paga pela qualidade, o que obriga o setor sucroalcooleiro a se aprimorar, conscientizar e capacitar seus técnicos além de investir em tecnologia e montar laboratórios para fins de análises tecnológicas da matéria-prima.

A AFOCAPI tem o maior quadro de associados de São Paulo e do Brasil, com 4.007 Fornecedores de cana, produzindo aproximadamente 7,94 milhões de toneladas, distribuídas em 17 usinas (ORPLANA, 2005). 
Para atender as necessidades dos associados, a AFOCAPI mantém um sistema de atendimento com vários setores de assistência direta aos seus associados e funcionários tais como: 1) Assistência Social e à Saúde que é feita no Hospital dos Fornecedores de Cana - HFC em Piracicaba, além de ambulatórios, clinicas e convênios em outros municípios; 2) Setor de Marketing que gerencia e divulga a entidade, além de coordenar cursos, palestras, treinamentos e convênios com outras entidades afins; 3) Setor Jurídico, para orientação e assistência; 4) Departamento Técnico Agronômico - DTA, que presta assistência técnica direta e personalizada, com quadro formado por Engenheiros Agrônomos, Técnicos em Agropecuária, Tecnólogos em Açúcar\&Álcool, Químico, Técnicos em Química, Biólogo, Topógrafos, funcionários da área administrativa e da lavoura, somando 40 profissionais. Estes nos seguintes setores de serviços: a) Laboratório de Solos em parceria com a COPLACANA; b) Laboratório de Nematologia, Pragas e Doenças, realiza análises e orientação técnica; c) Laboratório de Análise de Cana, que monitora a qualidade das canas, realiza análises de pré-colheita contrata e capacita Técnicos para monitorar a entrega de matéria-prima nos Laboratórios do Sistema de Pagamento de Cana - SPC de 17 unidades industriais, realiza análises de comparação entre esses laboratórios, auxilia em testes de novos produtos, aparelhos e trabalhos técnicos relacionados às inovações do SPC em parceria com a Câmara Técnica-Econômica - CANATEC/CONSECANA; d) Setor de Topografia, é informatizado e equipado com sistema GPS, "Plotter" e Estação Total; e) Estação Experimental, a qual realiza experimentação de clones e variedades de cana-de-açúcar em convênio com órgãos de P\&D como o Centro de Tecnologia Canavieira - CTC, e produz mudas de cana para os associados, além de grãos como milho e soja para renovação dos canaviais, viabilizando o programa de diversificação de culturas. Possui local para cursos e treinamentos próprios ou em parceria com o Serviço Nacional de Aprendizagem Rural - SENAR e com o Sindicato Rural de Piracicaba e Região - SINDIRPI. Mantém parcerias com empresas produtoras de insumos, 
máquinas, implementos e de tecnologias, instalando campos experimentais e demonstrativos aproveitados para dias de campo com associados; f) Setor Ambiental voltado à prevenção e orientação relacionada à legislação ambiental. Realiza projetos para recomposição de Áreas de Preservação Permanente APPs e de piscicultura, licenciamentos, outorgas, entre outros; g) informativo Canavieiro Paulista, que representa o canal de divulgação dos Fornecedores de Cana da Região de Piracicaba, com conteúdo voltado para discussões de interesse de Fornecedores e da agricultura; $h$ ) Grupos técnicos sendo os principais a CANATEC/CONSECANA - SP e o GT-ORPLANA; i) Assistentes de Campo, os quais formam o segmento de maior relevância que é a assistência técnica. Os Assistentes possuem uma rotina diária de atividades ligada diretamente à produção de cana-de-açúcar ou outras culturas. São realizadas 1.900 visitas/mês, correspondendo a 23.000/ano (AFOCAPI, 2004 e Ripoli \& Ripoli, 2004).

Farhat (2004) relata que as visitas compreendem coleta de amostras de solo e nematologia, regulagens de implementos, acompanhamento de instalação, manutenção e manejo das lavouras, vistorias em APPs e locais de implantação de projetos de piscicultura, convites para palestras e reuniões. Conjuntamente com os Monitores de Sacarose, fiscalizam ininterruptamente a matéria-prima entregue nas usinas durante a safra. Neste período os laboratórios do SPC são checados diariamente e o trabalho dos funcionários das usinas é monitorado durante as 24 horas. Neste período o DTA funciona em regime de plantão durante feriados e finais de semana, podendo o associado contar com este apoio.

A AFOCAPI mantém ainda parcerias com várias Entidades como: a Secretaria Estadual de Agricultura e Abastecimento - SAA/SP, o Serviço Nacional de Aprendizagem Rural - SENAR, Prefeituras Municipais e Secretarias, Sindicatos Rurais, Instituto Agronômico de Campinas - IAC, Instituto de Pesquisas Florestais - IPEF/ESALQ/USP, além do Centro de Integração Empresa Escola - CIEE. Participa da Organização de Plantadores 
de Cana da Região Centro Sul do Brasil - ORPLANA, da diretoria do CONSECANA e na CANATEC, além do Conselho Municipal de Desenvolvimento Rural de Piracicaba - COMDER, do Conselho de Desenvolvimento Rural de Charqueada, do Conselho Municipal de Planejamento e Desenvolvimento de Piracicaba - COMPLADEPI e do Comitê de Bacias Hidrográficas dos Rios Piracicaba, Capivari e Jundiaí (Farhat, 2004).

A COPLACANA foi fundada em 10 de outubro de 1948 (Farhat, 2003). Atua em todo o Estado de São Paulo e em outros estados brasileiros por meio de sua Matriz, em Piracicaba e mais 11 Filiais sediadas em Araras, Assis, Barra Bonita, Cerquilho, Charqueada, Chavantes, Cosmópolis, Iracemápolis, Nova Odessa, Rio Claro e Santa Cruz das Palmeiras. Seu seguimento mais importante é a comercialização de insumos e implementos, realizada por Engenheiros Agrônomos e Técnicos e vinculada à assistência técnica em aproximadamente 200.000 ha. O quadro social ativo é formado por 6.033 associados, sendo que $72 \%$ destes são mini e pequenos produtores rurais. $O$ perfil dos cooperados é diversificado, incluindo produtores de cana-de-açúcar, em maioria, além de produtores de milho, olerícolas, pastagens e bovinos, aves, suínos, ovinos, entre outros (COPLACANA, 2005).

A COPLACANA possui uma Fábrica de Ração, um conjunto de silos e um secador de grãos, conferindo maior capacidade de armazenamento para a região e incentivo à produção. Além disso, oferece um Laboratório de Solos moderno, informatizado, que está entre os melhores do Sistema de Qualidade do Instituto Agronômico de Campinas - IAC para análises de Macro e Micronutrientes. Este utiliza o Sistema Informatizado de Recomendações Agronômicas - SIRA e as análises são acompanhadas e revisadas por Agrônomos desde a saída do laboratório, com orientação ao usuário na compra dos corretivos e fertilizantes, até a aplicação no campo (AFOCAPI, 2004).

Desde 1997, antes mesmo da vigência da legislação de destinação final de agrotóxicos, já possuía uma unidade de recebimento de embalagens vazias, a Central Piracicaba. O trabalho de assistência sobre o processo é permanente, 
desde a comercialização dos produtos fitossanitários até a devolução da embalagem vazia. Sete Postos de Recebimento nas regiões das Filiais estão ligados à Central Piracicaba, com capacidade de recebimento de 50 toneladas por mês. Este trabalho é desenvolvido em parceria com o Instituto Nacional de Embalagens Vazias - inpEV (COPLACANA, 2004).

A entidade estimula a diversificação de culturas, como milho e soja, criando para esse fim setor específico. Também participa da produção em parceria, fornecendo insumos e prestando assistência técnica integral. A assistência técnica direta ao produtor inclui parceria com produtores mais experientes, profissionais e pesquisadores da área, empresas produtoras de insumos, promovendo sua inserção na cadeia produtiva (COPLACANA, 2004). A cooperativa desempenha um importante papel na área de assistência técnica e, principalmente na regulação de preços regionais dos insumos, máquinas $e$ implementos, uma vez que o mercado gira em torno dos seus preços. Ela repassa financiamentos via Crédito Rural ou em convênio com a Cooperativa de Crédito Rural dos Fornecedores de cana e Agropecuaristas de Piracicaba e Região - COCREFOCAPI, comercializa em grande escala, compra e vende com preços menores e em melhores condições.

Dessa forma a COPLACANA contribui para a diminuição e o equacionamento dos preços praticados nas regiōes em que atua e para a diminuição dos custos de produção. Além disso, fortalece os produtores e a produção e também mantém parcerias com outras entidades afins, universidades e prefeituras, nas áreas de inovações tecnológicas da agroindústria sucroalcooleira (Farhat, 2004).

Juntas, COPLACANA e AFOCAPI fortalecem a assistência técnica em função da evolução tecnológica e preenchem uma lacuna aberta pelo Estado. Constituem um importante elo entre a Universidade, a P\&D, o Produtor Rural e a Agricultura. Desempenham um papel essencial na área de assistência técnica à agricultura e na cadeia do Agronegócio, sem subvenção do Estado, apenas com verbas dos associados e cooperados. A assistência técnica é intensiva, 
direta, diária e personalizada, refletindo positivamente na produção de qualidade. Atestam a viabilidade do Cooperativismo e do Associativismo e que a assistência técnica ao Homem do Campo e ao sistema produtivo é uma forma de conduzir corretamente a produção, promover economia, diminuir custos, economizar energia, diminuir gastos de verbas públicas com melhor utilização dos recursos. Resta ao Estado fortalecer seu sistema de Assistência Técnica e Extensão Rural, importante para o melhor aproveitamento das áreas agricultáveis e para a verticalização da produção. Ainda, segundo o autor, afirma que a experiência com a parceria entre a COPLACANA e AFOCAPI, mantendo um sistema privado de assistência técnica, é importante para o sistema produtivo. Deve permanecer por revelar fortes elos da cadeia do agronegócio e por desempenhar significativamente a assistência técnica à agricultura e ao produtor rural e os Fornecedores de Piracicaba possuem um sistema integrado entre AFOCAPI e a COPLACANA, de assistência e defesa da classe (Farhat, 2004).

A Tabela 18, que apresenta a estratificação da região de Piracicaba, demonstrando que a maior parte da UPAs estão numa faixa entre 2 e 50 ha, revelando assim suas características fundiárias (LUPA, 1996). 
Tabela 18. Estratificação das UPAs da Regional Agrícola de Piracicaba, Estado de São Paulo, 1995/96

\begin{tabular}{lccc}
\hline \multicolumn{1}{c}{ ÁREA DAS UPAs (ha) } & N $^{\circ}$ DE UPAs & MÉDIA & TOTAL (ha) \\
\hline até 1 & 133 & 0,65 & 86,2 \\
1 a 2 & 198 & 1,6 & 317,7 \\
2 a 5 & 928 & 3,62 & $3.355,90$ \\
5 a 10 & 1.118 & 7,7 & $8.607,40$ \\
10 a 20 & 1.600 & 14,79 & $23.665,50$ \\
20 a 50 & 1.749 & 31,34 & $54.809,20$ \\
50 a 100 & 713 & 70,79 & $50.472,40$ \\
100 a 200 & 312 & 140,25 & $43.758,90$ \\
200 a 500 & 227 & 305,88 & $69.435,80$ \\
5001.000 & 75 & 665,97 & $49.947,80$ \\
1.000 a 2.000 & 33 & $1.358,58$ & $44.833,00$ \\
2.000 a 5.000 & 6 & $2.845,92$ & $17.075,50$ \\
5.000 a 10.000 & 0 & 0 & 0 \\
acima de 10.000 & 0 & 0 & 0 \\
\hline
\end{tabular}

Fonte: Secretaria de Agricultura e Abastecimento do Estado de São Paulo, Projeto LUPA, 1996. Escritório Regional de Piracicaba.

A Tabela 19 apresenta os tipos de culturas da região de Piracicaba, onde a cana-de-açúcar ocorre em aproximadamente 164 mil ha plantados, seguida pela área de pastagem e em terceiro lugar a vegetação natural. Embora a área de cana seja expressiva, as áreas de culturas perenes e anuais revelam-se bastante diversificadas. 
Tabela 19. Apresentação por tipo de cultura na Região Agricola de Piracicaba

\begin{tabular}{lcc}
\hline \multicolumn{1}{c}{ USO DO SOLO/ CULTURA/UPAS } & $\mathrm{N}^{\circ}$ DE UPAS & TOTAL (ha) \\
\hline Perene & 479 & $4.268,70$ \\
Semi-perene (cana-de-açúcar) & 4.168 & $164.132,90$ \\
Anual & 1.305 & $10.149,00$ \\
Pastagem & 4.707 & $137.236,70$ \\
Reflorestamento & 906 & $6.634,90$ \\
Vegetação natural & 2.512 & $21.643,10$ \\
Inaproveitada & 986 & $6.942,70$ \\
Inaproveitável & 1.296 & $6.433,40$ \\
Complementar & 5.118 & $8.923,90$ \\
& 7.092 & $366.365,30$ \\
\hline
\end{tabular}

Fonte: Secretaria de Agricultura e Abastecimento do Estado de São Paulo, Projeto LUPA, 1996. Escritório Regional de Piracicaba.

\subsection{A colheita de cana-de-açúcar no Brasil}

Conforme Carvalho Filho (2000) a colheita é a atividade que se inicia com o corte da cana no campo e termina quando esta cana chega à usina para o processamento. A colheita é a última operação realizada no campo, no processo de produção agrícola. Nos primórdios da agricultura, toda operação de colheita era realizada manualmente. A operação de colheita manual, da mesma forma que os processos manuais, é de baixa capacidade operacional e, portanto, é viável economicamente apenas em pequenas propriedades, onde a finalidade principal da produção é a subsistência do agricultor e sua família (Balastreire, 1987).

Até o início do século $X X$ o corte da cana-de-açúcar era manual, tal como nos dias de hoje. Porém, a cana era cortada crua, ou seja, sem queima prévia. Era despontada e amarrada em feixes, utilizando-se para este procedimento as pontas da própria cana. Em seguida eram carregados para o dorso de índios e escravos, depois para o dorso de mulas, carros de boi e transportados até o local de descarregamento nos engenhos. Nos centros mais desenvolvidos, 
como São Paulo, o transporte foi melhorado com o surgimento dos caminhões de pequeno porte e capacidade, já no início século XX. Estes transportavam a cana até os Engenhos Centrais ou Usinas. Era também utilizado transporte em vagões de trens que passavam nas proximidades das plantações. Com a expansão da cultura, tornou-se imperativo passar a queimar a palha da cana para facilitar o corte manual. Esta prática, segundo Szmrecsányi (1994), tornouse habitual na grande maioria dos estabelecimentos agrícolas dedicados a seu cultivo, tendo por principal objetivo facilitar e baratear o corte manual da cana e até do corte mecanizado.

Segundo relatos históricos a primeira máquina cortadora de cana foi patenteada em 1854 no Hawaí. Era tracionada por uma parelha de muares e, além de cortar a cana, revolvia folhas e palhas dos colmos com uma escova de arame. Carvalho Filho (2000) descreve sobre os primórdios da mecanização da colheita no Havaí (EUA), a qual teve início em $1906 \mathrm{com}$ a primeira cortadora autopropelida. Além disso, relata que em 1925 ocorreu a formação de um comitê de usineiros do Hawai com o objetivo de estudar "dispositivos econômicos do trabalho" e que em 1937 este comitê desenvolveu o primeiro protótipo integrado de colheita, cujo objetivo foi suprir a escassez de mão-deobra e reduzir o custo do corte manual.

De acordo com Veiga Filho (2000), o Brasil dá início a colheita mecânica no início dos anos 1950. As primeiras experiências em campo ocorreram logo depois do final da II Guerra Mundial, com a importação de máquinas do tipo cortadeiras de cana inteira, vinda dos Estados Unidos. Cardoso (1952) relata que a primeira experiência com uma máquina cortadora de cana foi realizada pela Usina Monte Alegre, em Piracicaba, SP, quando importou uma máquina da Louisiana (EUA).

Até o início dos anos 1970 o sistema de colheita era totalmente manual. Nesta época, a colheita mecanizada passa a ser introduzida em São Paulo, sendo mais estudada e desenvolvida quando entraram em operação comercial as máquinas colhedoras do tipo chopper (Ripoli, 1981 \& Zanca, 1980). A 
colheita mecanizada no Brasil já vinha sendo bastante discutida e estudada nos anos 1960/70. Nessa época foram realizadas as mais diversas tentativas de construção de máquinas capazes de facilitar o corte e o carregamento de cana no Brasil, mesmo que com tecnologia vinda de outros países, onde o sistema de colheita mecanizada era praticado havia mais tempo. O Hawaí e Austrália são locais que se obrigaram a desenvolver um sistema de colheita mecanizada, em função da escassez e conseqüente encarecimento da mão-de-obra, caso contrário, a cana ficaria na roça (Pinto, 1977). Segundo esta autor:

"Que nos reserva o futuro, em termos de colheita de canade-açúcar? Sem querer competir com os futurólogos famosos, acredito que as tendências já estão perfeitamente definidas, pelo menos para as próximas duas décadas. Caminharemos, no mundo açucareiro, para colhedeiras corta-pica-limpa-carrega cada vez mais robustas, produtivas e capazes de cortar cana crua, apresentando um produto mais limpo e com maior teor de açúcar, permitindo às usinas atingirem rendimentos de $120 \mathrm{a} 140 \mathrm{~kg}$ de açúcar por tonelada de cana moída. E para isso, no Brasil, muito concorrerá a introdução de um sistema racional de pagamento de cana, em função do açúcar recuperável contido na matéria-prima" (Pinto, 1977).

Segundo UNICA (2004), a colheita de cana crua é realidade em aproximadamente $25 \%$ da área colhida do Estado de São Paulo. Os rendimentos da extração de açúcar já ultrapassam os 120 a $140 \mathrm{~kg}$ e o sistema racional de pagamento de cana foi alcançado e vigora desde 1983, quando foi implantado o Sistema de Pagamento de Cana Pelo Teor de Sacarose - PCTS e Pureza. No estado de São Paulo, a partir de 1998, com a desregulamentação do Setor Sucroalcooleiro, o modelo CONSECANA para pagamento de cana é adotado em todo o Estado. Portanto, as previsões que foram feitas por Pinto em 1977, referindo-se ao pagamento da cana pelo açúcar recuperável, são realidade em 1998.

Nesse ano o setor sucroalcooleiro passa por desregulamentação
oficial, afastando-se o governo federal de diversas etapas da produção, 
principalmente aquelas concernentes à comercialização da cana-de-açúcar, do açúcar e do álcool (Moraes, 1999). Como conseqüência, ocorreu a liberação dos preços, antes estabelecidos pelo governo, que num primeiro momento, resultou em redução dos valores pagos pela cana aos Fornecedores (Banco do Brasil, 2000). As associações de classe, agregadas na ORPLANA e ÚNICA, passaram a ter um papel importante nas negociações, que resultaram na criação de um Conselho dos Fornecedores de Cana, Açúcar e Álcool do Estado de São Paulo - CONSECANA-SP, que passou a estabelecer a sistemática de pagamento e de contrato de venda e compra de cana-de-açúcar, reconduzindo os preços a uma certa estabilidade (CÂMARA PAULISTA DO SETOR SUCROALCOOLEIRO, 2004).

O novo modelo de pagamento de cana remunera a cana pelo teor de Açúcar Total Recuperável - ATR, cujos valores são calculados a partir dos preços dos produtos produzidos a partir da cana, tais como: açúcar mercado interno; açúcar mercado externo; álcool anidro; álcool hidratado; álcool residual e outros fins (CONSECANA, 2002).

Algumas regiões do Brasil, em função do cultivo em relevos declivosos, ainda utilizam animais para transporte, como é o caso de alguns estados do Nordeste.

Em São Paulo parte da colheita é feita utilizando o corte manual, seja de cana crua ou queimada, e também a colheita mecanizada.

\subsubsection{Sistemas de colheita}

As operações de corte, carregamento e transporte de cana-de-açúcar podem utilizar diferentes métodos: manuais, mecanizados, semi-mecanizados, em cana crua ou cana queimada.

Na Figura 2 Ripoli (1975) apresenta o sistema de global de colheita de cana-de-açúcar como uma etapa do sistema de produção. O sistema de colheita está dividido em três sub-sistemas: o sub-sistema de corte e 
carregamento; o sub-sistema de transporte e o sub-sistema de recepção. As fases intermediárias desses sub-sistemas são denominadas de interface.

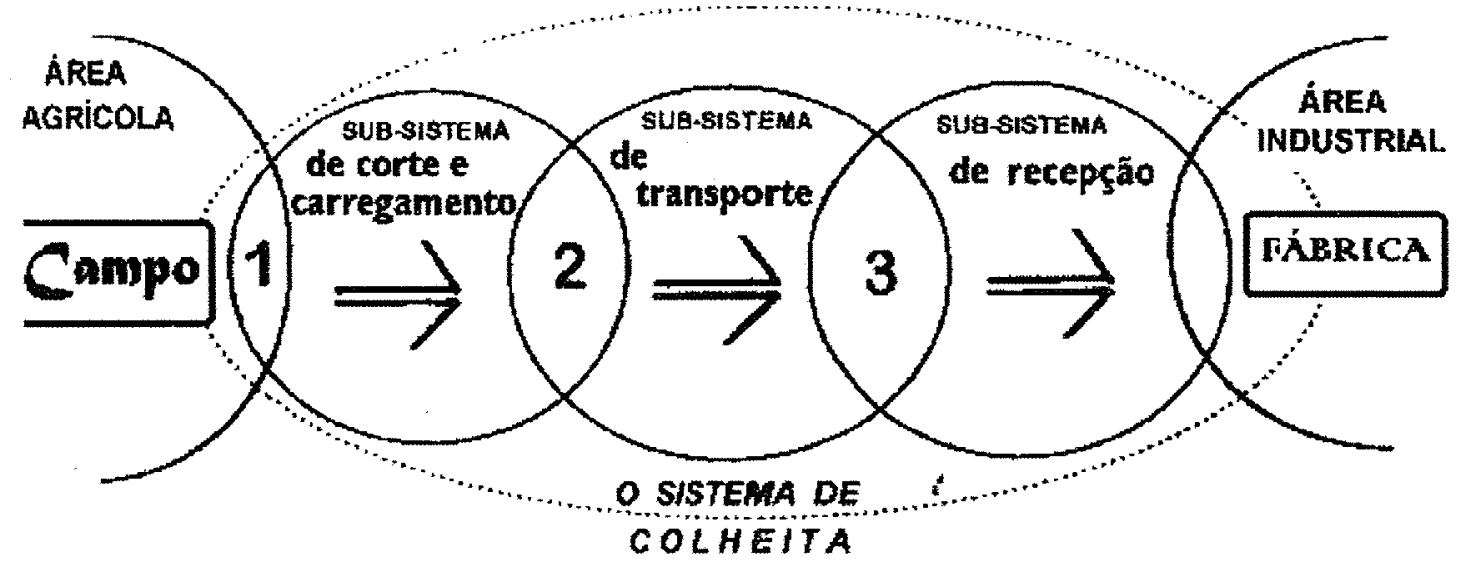

Figura 2 - Sistema global de colheita com sub-sistemas e interfaces. Interface 1: queima, desfolhante, sistema de plantio etc; Interface 2: transbordo, limpeza etc; Interface 3: descarregamento, sonda, limpeza etc. (Ripoli, 1975).

Cada sub-sistema tem interfaces que incluem aspectos comuns, os quais estabelecem um fluxo da matéria-prima do campo à indústria e que precisam ser alterados para compor-se ao novo arranjo técnico (Ripoli \& Paranhos, 1987). A interface 1 está relacionada com o preparo da área para o corte e carregamento, aplicação de maturadores, aceiros, queima, desfolhantes, análises técnicas de pré-colheita; a interface 2, ao transbordo e limpeza de carga (cana inteira) e, por fim, a interface 3, à pesagem da carga, recolhimento de amostra para análise tecnológica, descarregamento e se houver, a prélimpeza.

Conforme Ripoli (1975), o sistema global de colheita é um conceito que deve ser levado em conta e deve ser planejado de modo a permitir que não 
haja problemas que prejudiquem o decorrer da colheita. As interfaces têm que estar em sincronia com os sub-sistemas de corte e carregamento, transporte e recepção. Portanto, quando algum elo do sistema global é rompido, há reflexos negativos no resultado final da produção. Como exemplo sobre a interface $1 \mathrm{a}$ sistematização da área deve obedecer critérios de modo a facilitar a movimentação das colhedoras e a operação de colheita, diminuindo o pisoteio, arraste de terra, arranquio de socaria. Esta é a fase da cultura que demanda maior quantidade de mão-de-obra nas áreas dos pequenos e médios produtores de cana-de-açúcar. $\mathrm{Na}$ interface 2 o número de transbordos e caminhões devem estar em equilibrio para que o trabalho da colhedora não seja prejudicado, enquanto na interface 3 , o sub-sistema de recepção de matéria prima deve estar adaptado ao recebimento de cana picada. Portanto o sistema global deve ser muito bem planejado.

Segundo Ripoli (1996) os sistemas de colheita de cana-de-açúcar envolvem vários aspectos, relativos às condições de campo (solo, variedade, relevo, espaçamento, formato de talhão etc), tipos de equipamentos utilizados no processo e o gerenciamento.

No Brasil são utilizados três sub-sistemas distintos de colheita: a) manual, b) semi-mecanizado, c) mecanizado. Seja qual for o sub-sistema considerado, ele representa parte distinta de sistema global que envolve: o corte e carregamento, o transporte e a recepção da matéria prima (Ripoli, 1996).

A modalidade de colheita semi-mecanizada é a de maior utilização no país. Apresenta-se com corte manual, o carregamento mecânico e o transporte por veículos motorizados (tratores tracionando carretas ou caminhões). A etapa de carregamento é realizada por conjuntos de mecanismos hidráulicos formando uma estrutura, a qual, em regra geral, é montada sobre trator convencional de rodas. O conjunto formado máquina-trator tem por função recolher o material cortado e depositado sobre o terreno (manualmente ou por cortadoras amontoadoras ou ainda, por cortadoras-enleiradoras), colocando-o 
sobre unidades de transporte. Todavia, existem ainda, apesar do uso restrito, carregadoras autopropelidas (Ripoli, 1996).

De qualquer forma, persistem no Estado de São Paulo quase todas as modalidades de sistema de corte, carregamento e transporte de cana. A cana crua é cortada manualmente nas faixas à beira de estradas e demais áreas onde é proibida a queima e em viveiros de mudas. A grande maioria do corte manual, entretanto, é realizado em cana queimada. Já a colheita mecanizada pode ocorrer tanto em cana crua como cana queimada.

No setor sucroalcooleiro, a colheita mecanizada encontra-se em expansão, embora não seja aplicada ainda na totalidade das áreas cultivadas para fins industriais. Mesmo nas lavouras dos Fornecedores de cana, a maior parte da colheita emprega mão-de-obra para a realização do corte. As transformações estão acontecendo com maior velocidade em áreas das unidades industriais e mais lentamente nas áreas de Fornecedores de cana. Entretanto, grande parte das unidades industriais e Fornecedores de cana ainda utilizam este sub-sistema, gerando necessidade de grande quantidade de mão-de-obra. O corte manual é precedido da queima da palha da cana para efeito de colheita. Há exigências nos acordos coletivos entre os sindicatos dos trabalhadores, da indústria e dos produtores rurais, para que a cana seja queimada para efeito da despalha.

O corte manual da cana queimada tem um rendimento médio de 8,0 toneladas/homem/dia, enquanto o de cana crua tem rendimento bem menor, com média de 3,0 toneladas/homem/dia (ORPLANA, 2000). O corte manual de cana crua além de baixo rendimento custa mais caro, chegando a ser mais que o dobro do preço pago pelo corte da cana queimada (AFOCAPI, 2001).

Segundo Belodi (1998), a atividade da colheita de cana-de-açúcar representa $38 \%$ do custo de produção da cultura. Para chegar a este valor, o autor considerou $100 \%$ de corte manual, sendo $90 \%$ deste em cana queimada e $10 \%$ em cana crua, e transporte por treminhões em um raio médio de 27 quilômetros. 


\subsubsection{Queima da palha para efeito de colheita e a questão ambiental}

A queima da palha insere-se em uma das principais fases da produção de cana-de-açúcar: a colheita. A queima como método despalhador para a facilitação do corte manual de cana-de-açúcar na operação de colheita é um assunto polêmico, colocando em conflito empresários, técnicos, ambientalistas, governos e sindicatos. Esta questão é um problema que vem sendo discutido na maior parte dos países produtores de cana-de-açúcar e por essa razão, o corte manual realizado com a cana queimada vem sendo substituído pelo corte mecânico da cana crua (Romanach \& Caron, 1999).

Para a população em geral, o principal incômodo gerado pela prática da queima do canavial é a fuligem. Composto basicamente de carbono da palha queimada, este material é carregado pelo vento, e vem a cair a quilômetros do local de origem, sujando quintais, telhados, roupas, piscinas, coberturas. Causa assim, grande incômodo aos moradores das cidades, além de gerar suspeitas de provocar alergias e problemas respiratórios (Gonçalves, 2001), apesar dos estudos indicando a ausência de relação entre as doenças respiratórias crônicas e qualidade do ar nos municipios canavieiros durante a safra (Miranda et. al. 1995). A queima, além da ação biocida em relação à fauna, à flora e aos microorganismos, aumenta a temperatura e diminui a umidade natural dos solos, levando a uma maior compactação e a uma perda de porosidade dos mesmos, além de proporcionar uma polimerização de suas substâncias húmicas, assim como perda de nutrientes, seja para a atmosfera (via combustão) seja para as águas (por posterior lavagem e lixiviação), (Gonçalves, 2000).

Conseqüentemente, os diversos problemas causados pela queima sobre o ambiente vieram a se somar à força da insatisfação popular, ganhando uma grande dimensão política nas regiões canavieiras do Estado de São Paulo, onde proliferaram-se ações judiciais contra a prática da queimada, baseadas na 
Constituição Federal de 1988, a qual proibia o uso do fogo como prática agrícola Szmrecsányi (1994).

A COOPERSUCAR (1989) aborda a questão ambiental sob o ponto de vista da produção, afirmando que as principais fontes poluidoras são a queima da cana, a lavagem da cana, a torta de filtro, a vinhaça e a queima do bagaço. Afirma ainda que, além desses resíduos possuírem características economicamente atrativas para o reaproveitamento, seu potencial poluidor do ambiente é tecnicamente passivel de controle.

Verifica-se pela polêmica existente, brevemente apontada nas citações acima, que se faz necessário o desenvolvimento de políticas realistas de monitoramento de impactos ambientais e criação de alternativas para mitigar os problemas geados.

\subsubsection{Legislação vigente e sua relação com os Fornecedores de cana}

O decreto $n^{\circ} 28.848$ de 30 de agosto de 1.988 proibiu as queimadas em áreas consideradas de preservação ambiental, próximas a redes elétricas, rodovias e ferrovias e próximas ao perímetro urbano. O setor canavieiro, teve que adequar-se aos dispositivos da lei no sentido de: a) obter licença dos órgãos governamentais, através do pedido formal, para as áreas onde era praticada a queimada; b) respeitar os horários preestabelecidos para a queima; c) dispor de uma equipe de plantão na hora da queimada para emergências em caso de propagação do fogo, inclusive com carros pipa de combate a incêndios; e d) restringir rigorosamente a queima nas áreas limitadas pelo decreto.

O Decreto 2.661 (Brasil, 1998) regulamenta o parágrafo único da Lei 4771/65 mediante o estabelecimento de normas de precaução relativas ao emprego do fogo em práticas agropastoris e florestais e dá outras providências. No estado de São Paulo o assunto é regido por legislação específica, porém baseia-se no decreto supra citado para regular a queima da palha de cana-deaçúcar para efeito de colheita. O Decreto 42.056 (São Paulo, 1997) inaugura a 
legislação ambiental especifica para o setor sucroalcooleiro, uma vez que normatiza a queima da palha da cana-de-açúcar. Este decreto estabelece um cronograma para a eliminação da queima da palha, ao fim do qual essa prática deverá estar erradicada nos canaviais. O acompanhamento desse cronograma foi feito pela Coordenadoria de Assistência Técnica Integral - CATI, que estabeleceu o Plano de Eliminação de Queimadas (PEQ) e pela Companhia de Tecnologia e Saneamento Básico - CETESB, que pune as infrações ambientais com multas.

O decreto $n^{\circ} 42.056$ (São Paulo, 1997), vigorou até a promulgação da Lei $n^{\circ} 10.547$ (São Paulo, 2000), a qual dispõe sobre o emprego do fogo como práticas agrícolas, pastoris e florestais no Estado de São Paulo. Essa Lei estabelece regras de execução e medidas de precaução a serem obedecidas e as distâncias a serem observadas de 15 até $100 \mathrm{~m}$ que englobam as áreas de restrições de queima a partir das faixas de segurança de linhas de transmissão de energia elétrica, de subestações e de estações de telecomunicação e de rodovias e ferrovias, e de $50 \mathrm{~m}$ a partir de aceiro ao longo de Unidades de Conservação Ambiental. Estabelece também que o emprego do fogo depende de autorização prévia junto à Secretaria do Estado do Meio Ambiente - SMA. Trata também da redução gradativa do emprego de fogo como método despalhador para o corte de cana-de-açúcar, em áreas possiveis de mecanização da colheita, não podendo a redução ser inferior a um quarto da área mecanizável de cada unidade agro-industrial, a cada período de cinco anos. As lavouras de até 150 ha não ficaram sujeitas à redução gradativa do emprego do fogo, o que foi um atenuante para os pequenos Fornecedores. A regulamentação posterior dada pelo decreto número 45.870 (São Paulo, 2001), estabelece que a redução gradativa deverá ocorrer considerando-se a área integral e não somente aquela possivel de mecanização da colheita.

A Lei n 10.547 (São Paulo, 2000) foi revogada com a publicação da Lei 11.241(São Paulo, 2002), regulamentada pelo Decreto 47.700 (São Paulo, 2003). Esta dispõe especificamente sobre a eliminação gradativa do uso do 
fogo como método despalhador e facilitador do corte de cana-de-açúcar e determina as obrigações dos produtores de cana, sejam eles os produtores independentes ou as unidades industriais, para que a queima possa ser efetuada dentro da legalidade.

O uso do fogo passou a ser denominado "Queima Controlada" e a emissão de sua autorização passou a ser responsabilidade da SMA. Assim, a redução gradativa do emprego do fogo na cana-de-açúcar passou a ser limitada às áreas passiveis de mecanização de colheita. Desta forma, em todas as áreas canavieiras com declividade superior a $12 \%$ o uso do fogo voltou a ser permitido, por tempo determinado, sob a autorização prévia SMA (Gonçalves, 2001).

Assim a legislação estabelece critérios para determinar os parâmetros de área e prazos para a eliminação da queima em função da área de cana a ser colhida em cada Unidade de Produção Agrícola - UPA no ano corrente e da declividade do terreno. Dessa forma, os critérios se aplicam às dimensões das áreas contíguas de cana dentro da paisagem, independentemente das dimensões dos canaviais colhidos por pessoa física ou jurídica. Nas UPAs com áreas de pelo menos 150 ha a serem colhidos no ano e com declividade inferior a $12 \%$, desde que as condiçōes de solo permitam a mecanização da colheita, a partir de 2006, a cada 5 anos a área a ser cortada sem queima aumenta sucessivamente para $30 \%, 50 \%, 80 \%$ e a partir de 2021 toda a área passa ser cortada crua. As usinas são exceções, pois todas suas UPAs e de seus acionistas, mesmo aqueles que isoladamente são menores que 150 ha, são consideradas no conjunto, logicamente sempre maiores que 150 ha.

Nas UPAs com áreas colhidas no ano menores que 150 ha ou com declividade superior a $12 \%$ consideradas não mecanizáveis para colheita a partir de 2011 e até 2015 , a cada 5 anos aumenta em $10 \%$ a área de cana cortada sem queima. De 2020 até 2030 esse percentual aumenta em 20\% passando essas UPAs a cortarem sem queima pelo menos $50 \%$ da área a ser colhida, e a partir de 2031 toda a área passa a ser cortada sem queima. Nessa 
condição, abaixo de 150 ha, encontra-se a maioria dos Fornecedores de Piracicaba conforme demonstra a Tabela 24.

A Tabela 20 apresenta um resumo da evolução que deve ser cumprida para a eliminação da queima.

Tabela 20. Quadro evolutivo da eliminação da queima da Lei 11.241/2002 e seu Decreto No 47.700/2003. Apresenta a área mecanizável, nãomecanizável e percentagem de eliminação de queima

\begin{tabular}{|c|c|c|}
\hline ANO & ÁREA MECANIZÁVEL ONDE NĀO SE PODE EFETUAR A QUEIMA & \% DE ELIMINAÇÃO DA QUEIMA \\
\hline $\begin{array}{l}1^{\circ} \text { ano } \\
\{2002\}\end{array}$ & $20 \%$ da área cortada & $20 \%$ da queima eliminada \\
\hline $\begin{array}{l}5^{\circ} \text { ano } \\
(2006)\end{array}$ & $30 \%$ da área cortada & $30 \%$ da queima eliminada \\
\hline $\begin{array}{l}10^{\circ} \text { ano } \\
(2011)\end{array}$ & $50 \%$ da área cortada & $50 \%$ da queima eliminada \\
\hline $\begin{array}{l}15^{\circ} \text { ano } \\
(2016)\end{array}$ & $80 \%$ da área cortada & $80 \%$ da queima eliminada \\
\hline $\begin{array}{r}20^{\circ} \text { ano } \\
(2021)\end{array}$ & $100 \%$ da área cortada & Eliminaçăo total da queima \\
\hline ANO & $\begin{array}{l}\text { ÁREA NĀO MECANIZAVEL COM DECLIVIDADE SUPERIOR A } 12 \% \text { EIOU MENOR DE } 150 \\
\text { ha (CENTO E CINQUUENTA HECTARES) ONDE NĀO SE PODE EFETUAR A QUEIMA }\end{array}$ & $\begin{array}{c}\% \text { DE ELIMINAÇÄO DA } \\
\text { QUEIMA }\end{array}$ \\
\hline $\begin{array}{l}10^{\circ} \text { ano } \\
(2011)\end{array}$ & $10 \%$ da área cortada & $10 \%$ da queima eliminada \\
\hline $\begin{array}{l}15^{\circ} \text { ano } \\
(2016)\end{array}$ & $20 \%$ da àrea cortada & $20 \%$ da queima eliminada \\
\hline $\begin{array}{l}20^{\circ} \text { ano } \\
(2021)\end{array}$ & $30 \%$ da área cortada & $30 \%$ da queima eliminada \\
\hline $\begin{array}{l}25^{\circ} \text { ano } \\
(2026)\end{array}$ & $50 \%$ da área cortada & $50 \%$ da queima eliminada \\
\hline $\begin{array}{l}30^{\circ} \text { ano } \\
(2031)\end{array}$ & $100 \%$ da área cortada & Eliminaçāo total da queima \\
\hline
\end{tabular}

Fonte: Lei 11.241 - D.O.E. São Paulo, 2002.

A Lei 11.241 também estabelece alguns mecanismos para que os interessados apresentem uma documentação completa, possibilitando o chamado requerimento de queima controlada e o habilitando para os procedimentos da queima. Há também necessidade de uma comunicação prévia para a Secretaria de Meio Ambiente, de no mínimo 96 h, para obterem autorização da queima controlada nas áreas onde ainda é permitida a queima. 
A resolução SMA - 12/2005 informa as instruções detalhadas para esses procedimentos de requerimento e comunicação prévia. Sendo assim, o cenário futuro aponta para a necessidade de se encontrar alternativas ao uso da queima como facilitador do corte manual.

A Figura 3 mostra uma UPA com declividade maior que $12 \%$, utilizada para o cultivo da cana-de-açúcar. Demonstra também a fase de colheita realizada com cana queimada e corte manual, com impedimentos à colheita mecanizada.

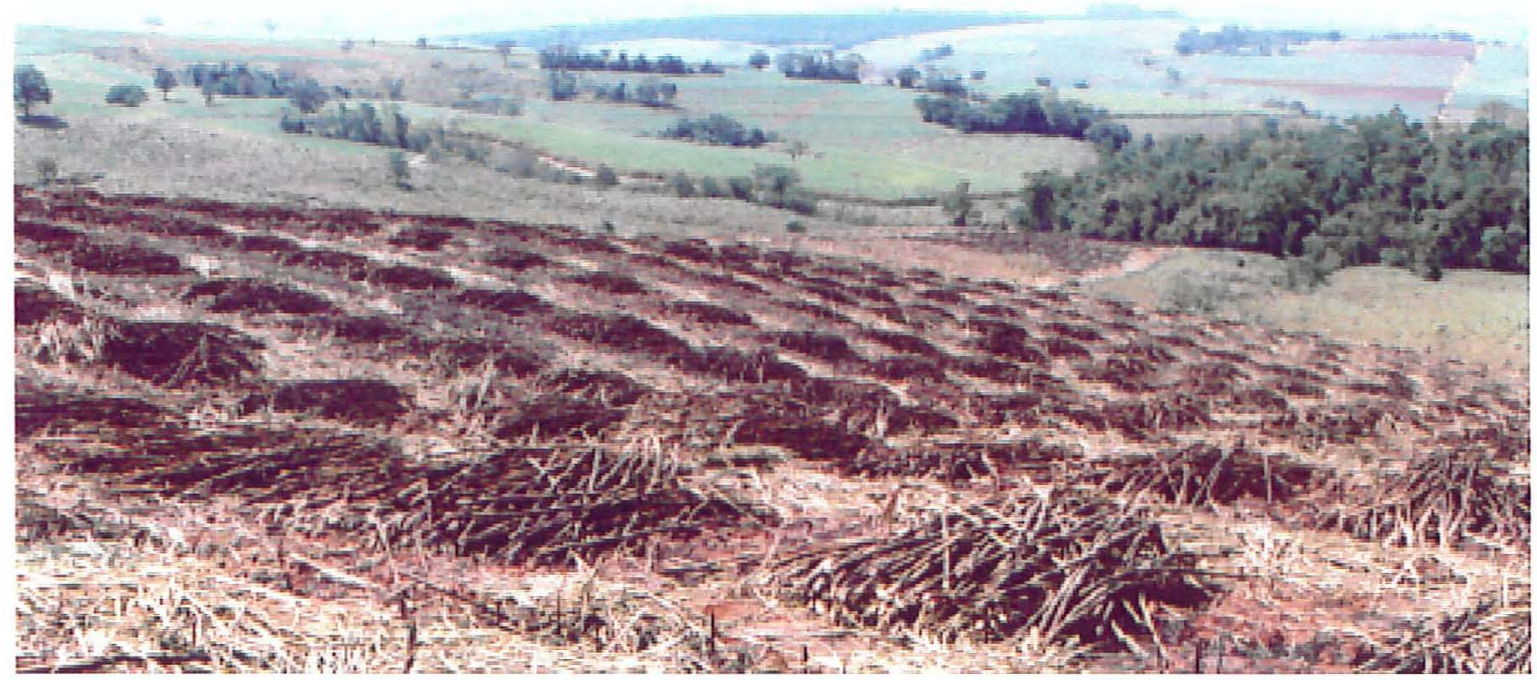

Figura 3 - Área de cana com declividade maior que 12\%, cana queimada e corte manual, com impedimentos à colheita mecanizada. Foto: Marcos Farhat, 2003

\subsubsection{Das questões do trabalho}

O principal objetivo da queima controlada é a despalha da canade-açúcar como método facilitador da colheita manual. Esta prática auxilia na eliminação da palha, facilitando o trabalho dos profissionais do corte, possibilitando um ambiente mais ventilado, amplo domínio visual da área e reduzindo os riscos de acidentes tanto com a palhada quanto ao ataque de 
animais peçonhentos. Além disso a queima aumenta o rendimento operacional e possibilita a colheita de uma matéria prima de melhor qualidade, pois diminuirá a incidência de impurezas vegetais e, após o carregamento, do arraste também de impurezas minerais.

Gonçalves \& Souza (1998b) afirmam que o impacto da proibição da despalha de cana por queima sobre a demanda de força de trabalho agropecuário é grande, o que significa desempregar algo entre 18,8\% e 64,9\% da mão de obra que atualmente encontra trabalho na lavoura canavieira. Em função da importância dessa cultura para a demanda de força de trabalho agropecuário, os efeitos estimados são de redução de $10,7 \%$ a $29,3 \%$ da demanda de força de trabalho global do meio rural paulista. De acordo com os autores, as economias das regiões produtoras de cana para indústria dificilmente abrirão a possibilidade de reinserção dessa mão de obra desqualificada, a não ser mediante intenso programa de treinamento, necessariamente vinculado a grandes investimentos e políticas governamentais para educação.

Segundo (Balsadi et al. 1995. e SEADE, 1997), a cana-de-açúcar tem sido a atividade mais importante em relação a demanda pela força de trabalho na agricultura do estado de São Paulo, ocupando, em 1993, 40,6\% do total, crescendo para quase a metade em 1996, mesmo com queda de $10 \%$ na demanda total.

Veiga Filho (1995), ao estudarem o impacto da mecanização da colheita de cana na substituição da força de trabalho em São Paulo, estimaram que poderia haver uma perda acumulada de 38.000 empregos-equivalentes na colheita da cana no período 1994-2000, o que equivaleria a uma taxa de desemprego inicial de $7,5 \%$ e final próxima a $23 \%$, para uma área mecanizada de aproximadamente $46 \%$ no ano 2000 .

Um exemplo das dificuldades enfrentadas no setor sucroalcooleiro com a conversão da cana queimada para a cana crua é o rendimento do trabalhador rural, que chega a cair pela metade com a mudança de sistema. Segundo Ripoli 
et al. (1995), tal situação encarece significativamente a operação na cultura, além de criar uma indesejável redução nos ganhos dos trabalhadores.

Apesar das possiveis conseqüências sócio-econômicas decorrentes da mecanização nas regiōes canavieiras, de acordo com a EMBRAPA (2002) vários aspectos são favoráveis ao corte de cana-de-açúcar sem queima. Estes têm sido abordados por diversos autores, como Furlani Neto et al. (1997) e Spavorek (1997), segundo os quais, além de evitar as emissões dos gases de efeito estufa, a prática da colheita de cana crua aumenta a quantidade de cobertura vegetal do solo nas soqueiras, diminuindo a erosão e aumentando a infiltração de água. Também acarreta melhora da qualidade tecnológica (com diminuição de impurezas minerais) e evita a perda de energia, apesar do menor rendimento de corte das máquinas e maior quantidade de impurezas vegetais.

A evolução tecnológica é gradativa e exige o desenvolvimento de políticas realistas de reciclagem para o reaproveitamento de mão-de-obra. Seródio (1999) destaca a questão dos empregos como sendo um fator importante a ser considerado, posto que são gerados um milhão de empregos diretos na agroindústria canavieira no Brasil, sendo 511 mil na produção de cana-deaçúcar e os demais distribuídos nas diversas atividades da agroindústria de açúcar e de álcool. No Estado de São Paulo são 600.000 postos de trabalho diretamente ligados ao setor, sendo que o piso salarial dos trabalhadores do setor é $70 \%$ maior que o salário mínimo, segundo dados da UNICA (1999, 2002). Porém, deve ser lembrado que uma parte significativa destes empregos está ameaçada, já que a proibição de queimadas como método de despalha impõe o uso de colhedoras mecânicas, com a conseqüente redução da mão-deobra empregada (Moraes, 1999).

A Tabela 21 apresenta planilha de custos otimizados de implantação de um hectare de lavoura de cana-de-açúcar na macro-região de Piracicaba (AFOCAPI, 2005). Os valores apresentados são referentes apenas para a implantação da lavoura, não fazendo parte desta planilha itens como capital de giro, valor da terra, valor de arrendamentos, impostos e taxas, e custos 
administrativos. Porém, para efeito de custos da lavoura, os dados podem ser considerados fidedignos e atualizados. Essa planilha é revisada e atualizada pela AFOCAPI a cada mês com valores orçados em fabricantes e revendedores de insumos, entre outros produtos e serviços. No entanto, a mão-de-obra para o corte de cana está estabelecida na faixa referente à colheita, como parte do CCT (corte, carregamento e transporte). O CCT representa aproximadamente $25,5 \%$ do valor total de implantação da lavoura, podendo significar um percentual maior, dependendo dos resultados finais no pós-colheita e do rendimento relacionado à produtividade em toneladas de cana por há, em ATR. Por outro lado, o corte manual significa $44 \%$ do valor do CCT.

A ORPLANA (2005) calcula o custo total de produção, considerando cana com $144 \mathrm{~kg}$ de ATR por tonelada, produtividade agrícola de 85 toneladas por ha e 5 cortes na safra 2004/05. Nesses termos o custo seria de $R \$ 0,2729$ por $\mathrm{kg}$ de ATR, enquanto o custo operacional estaria em torno de $R \$ 0,1996$. O arrendamento representa $14,8 \%$ (R\$ 0,0405 por $\mathrm{kg}$ de ATR) do custo total, enquanto o CCT representa $31,4 \%(R \$ 12,32 / t)$ do total e $42,8 \%$ (R\$ 0,0856 por $\mathrm{kg}$ de ATR) do custo operacional. Considerando-se as despesas com colheita, tratos culturais da soqueira, administração e Funrural, cujos pagamentos ocorrem durante a safra, ter-se-ia um desembolso de aproximadamente R\$ $21,44 / \mathrm{t}$ ou $\mathrm{R} \$ 0,1489$ por $\mathrm{kg}$ de ATR. Nota-se que quando o custo envolve área de arrendamento, as despesas se elevariam para $R \$ 27,27 / \mathrm{t}$ ou $\mathrm{R} \$ 0,1894 / \mathrm{kg}$ de ATR. Conforme o preço do ATR de março, que foi de $R \$ 0,2424 / \mathrm{kg}$, o desembolso, incluindo arrendamento, representa $78,1 \%$ e excluindo 0 arrendamento representaria $61,5 \%$ do preço médio do $\mathrm{kg}$ de ATR. O custo de produção apresentado leva em consideração produtividade média de 85 tha, com $144 \mathrm{~kg}$ de ATR por tonelada, em 5 cortes e está em $\mathrm{R} \$ 28,75$. O preço do corte foi de $\mathrm{R} \$ 4,84$ por tonelada, representando valor total de $\mathrm{R} \$ 411,66$ por ha colhido somente com relação à mão-de-obra de corte, comprometendo $12,3 \%$ do valor total do custo de produção. 
Tabela 21. Custo de implantação da lavoura e produção padrão para cana planta dos Fornecedores de cana da macro-região de Piracicaba, por ha, com atualização em 15/04/2005

\begin{tabular}{|c|c|c|c|c|c|}
\hline & & & coef & $\mathrm{R} \$$ & totais $\mathrm{R} \$$ \\
\hline \multicolumn{6}{|l|}{ SISTEMATIZAÇĀO } \\
\hline a) Levantamento Topográfico & & $H D$ & 1,00 & 90,0000 & 090,0000 \\
\hline $\begin{array}{l}\text { b) Amostragem de solo e } \\
\text { análises }\end{array}$ & & HD & 1,00 & 18,0000 & 018,0000 \\
\hline c) Monitoramento de pragas & & HD & 1,00 & 52,0000 & 052,0000 \\
\hline Subtotal & & & & & 160,0000 \\
\hline II. PREPARO DE SOLO & "Máquina & & & & \\
\hline 1. Convencional & Potência & $\mathrm{h} / \mathrm{ha}$ & h/ha & & \\
\hline a) Mecanização & & & & $\mathrm{R} \$$ & totais $\mathrm{R} \$$ \\
\hline Erradicação quimica & III & 0,75 & 0,18 & 25,8900 & 024,0777 \\
\hline Aplicação Calcário & III & 1,00 & 0,125 & 25,8900 & 029,1263 \\
\hline Gradagem pesada I & $\|$ & 2,50 & 0,125 & 41,6600 & 0 109,3575 \\
\hline Terraço/Curvas de Nivel & II & 2,50 & 0,125 & 41,6600 & 0109,3575 \\
\hline Acabamento Terraço & 1 & 0,41 & 0 & 55,7900 & 022,8739 \\
\hline Gradagem pesada II & II & 2,50 & 0,125 & 41,6600 & 0109,3575 \\
\hline Subsolagem & $\|$ & 1,60 & 0,125 & 41,6600 & 071,8635 \\
\hline Aração & 11 & 3,20 & 0,125 & 41,6600 & 0138,5195 \\
\hline Gradagem Niveladora & 11 & 1,60 & 0,125 & 41,6600 & 071,8635 \\
\hline Conservação Carreador & II & 0,30 & 0 & 41,6600 & 012,4980 \\
\hline Carregamento de Calcário & III & 0,15 & 0,125 & 25,8900 & 07,1198 \\
\hline Sulcação e adubaçăo & 11 & 2,00 & 0,125 & 41,6600 & 088,5275 \\
\hline Subtotal & & & & & 794,5421 \\
\hline b) Mão de obra & & & coef & $R \$$ & totais R\$ \\
\hline Auxiliar na aplicação de corretivo & & HD & 0,25 & 19,7800 & 04,9450 \\
\hline Auxiliar na aplicaçāo de herbicid: & & HD & 0,10 & 19,7800 & 01,9780 \\
\hline Subtotal & & & & & 6,9230 \\
\hline
\end{tabular}


Tabela 21. Custo de implantação da lavoura e produção padrão para cana planta dos Fornecedores de cana da macro-região de Piracicaba, por ha, com atualização em 15/04/2005 (cont.)

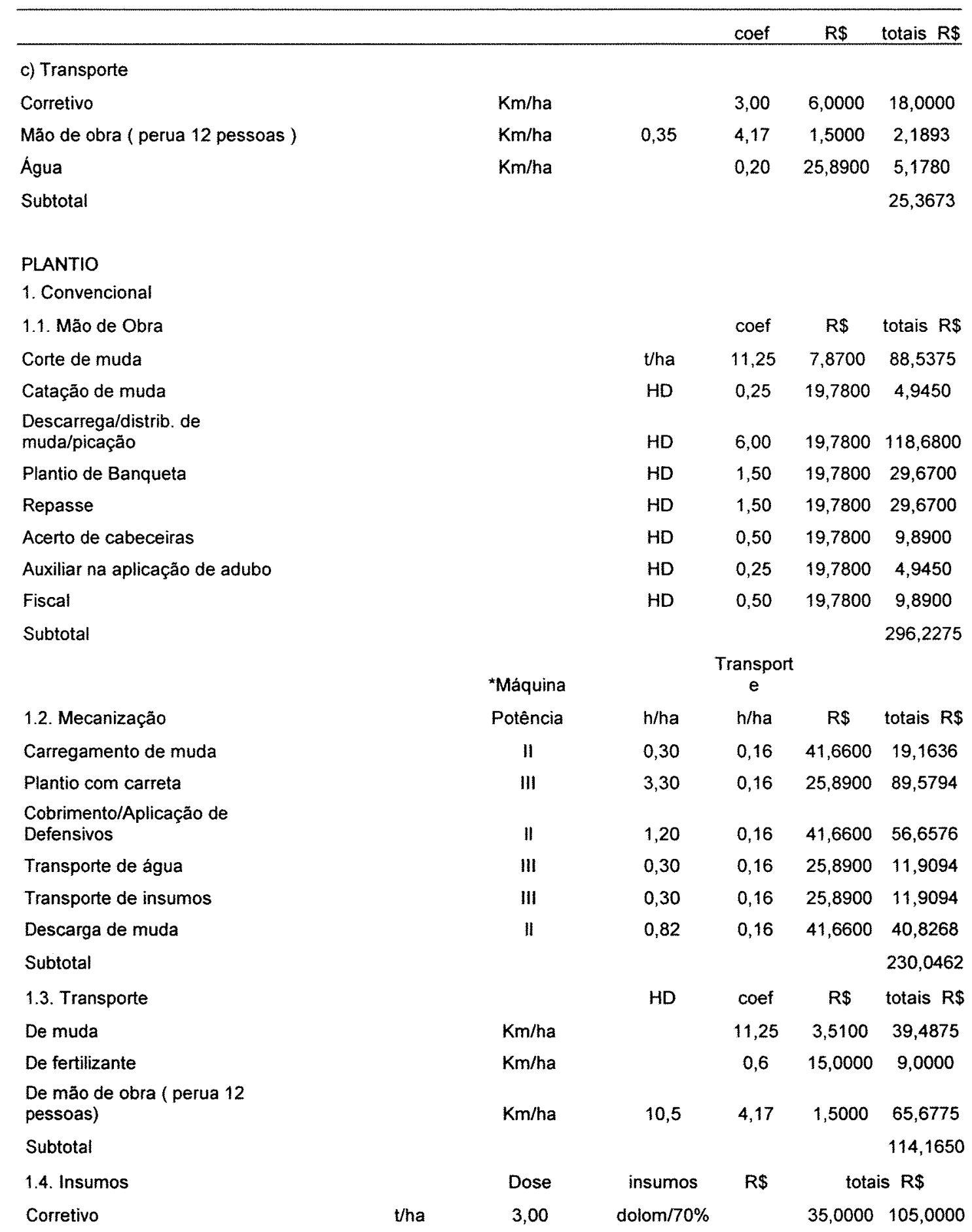


Tabela 21. Custo de implantação da lavoura e produção padrão para cana planta dos Fornecedores de cana da macro-região de Piracicaba, por há, com atualização em 15/04/2005 (cont.)

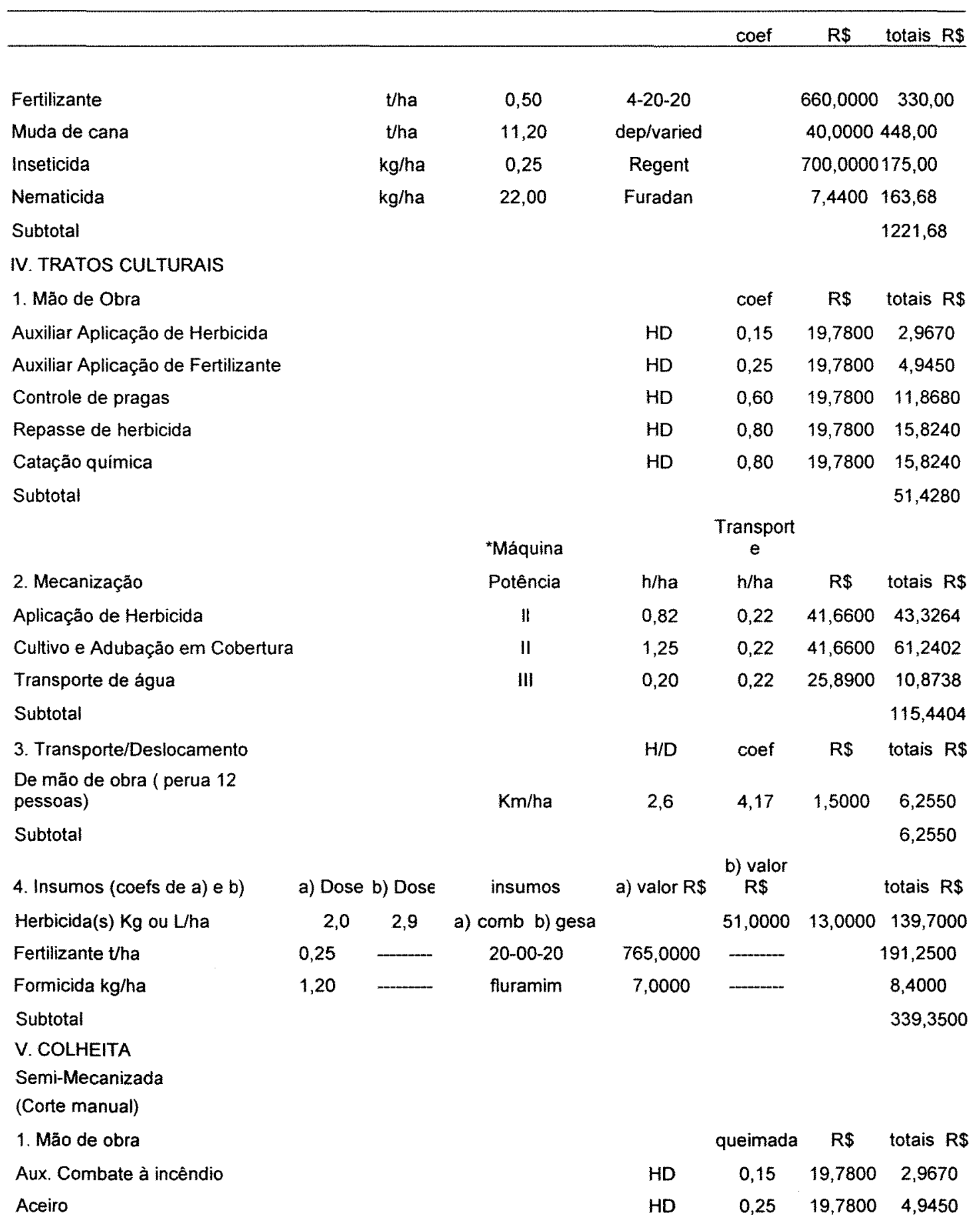


Tabela 21. Custo de implantação da lavoura e produção padrão para cana planta dos Fornecedores de cana da macro-região de Piracicaba por há, com atualização em 15/04/2005 (cont.)

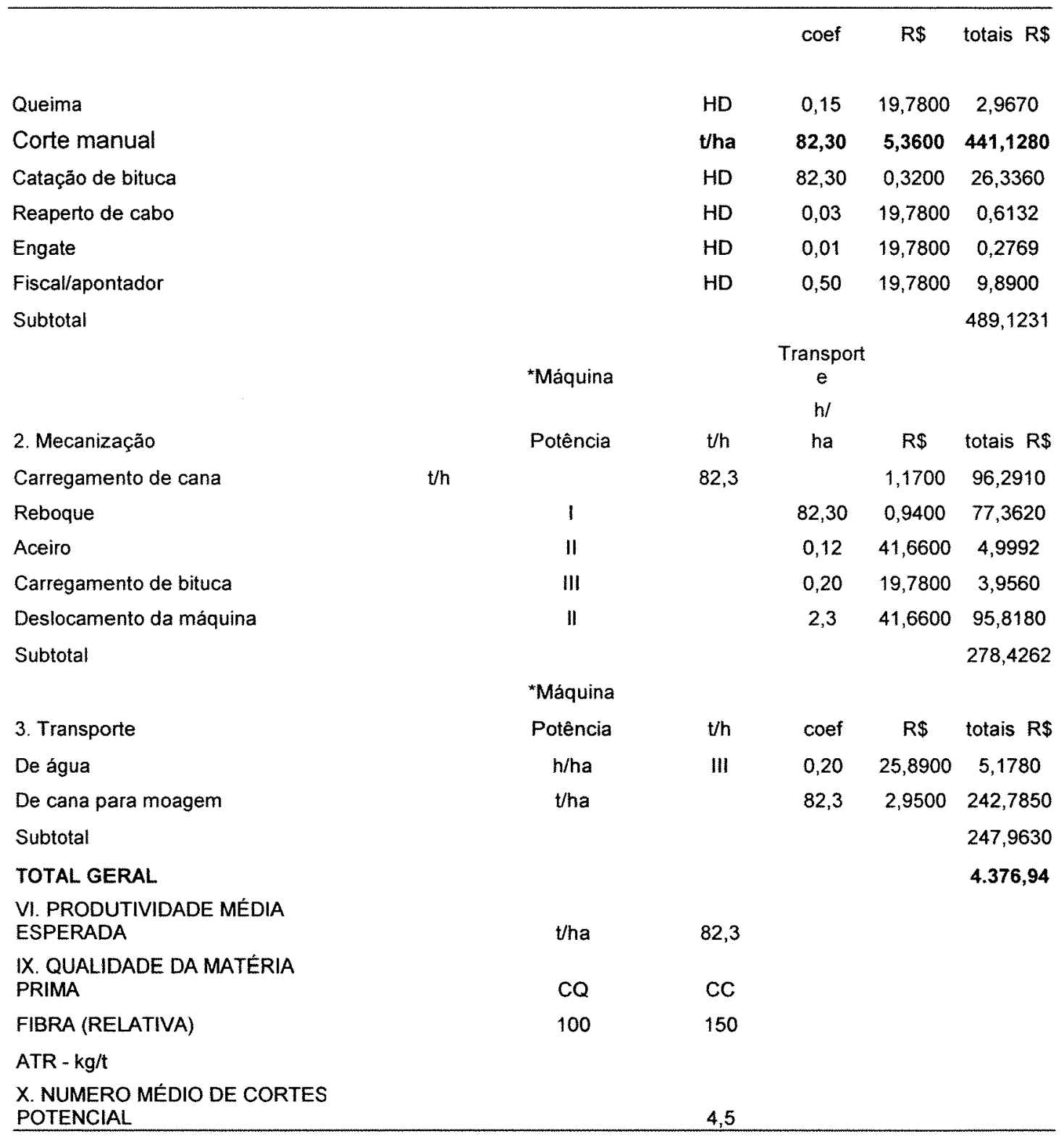

* Máquina adequada àquele tipo de serviço; I - máquina adequada - poténcia até $100 \mathrm{HP}$; II máquina adequada - potência de 100 a $140 \mathrm{HP}$; III - máquina adequada - potência acima de $140 \mathrm{HP} ; \mathrm{h} / \mathrm{ha}$ - horas por hectares; tha - toneladas por hectares; CQ - cana queimada; CC cana crua; HD - diária $\mathrm{km} / \mathrm{ha}$ - quilômetros por hectares; L/ha - litros por hectares; $\mathrm{kg} / \mathrm{ha}$ - quilos por hectares; furadan $100 \mathrm{gr}$; comb - combine; gesa - gesapax 500; dolom - dolomítico com prnt $=70 \%$; dep/varied - depende da variedade; coef - coeficiente; ATR - Açúcar Total Recuperável. Fonte: AFOCAPI, 2005. 


\subsubsection{Utilização do palhiço para a produção de energia}

Segundo Ripoli et. al. (2000), o Brasil é um país com abundantes recursos de biomassa, sendo a cana-de-açúcar uma cultura que oferece um grande potencial de geração de energia elétrica, produzida por meio da utilização do palhiço (ponteiros, folhas verdes e palhas). Estes podem ser recolhidos e queimados para produção de vapor para geração de eletricidade ou convertidos em álcool carburante. Estima-se que do palhiço e do bagaço, $7.0 \times 10^{6}$ e $5.5 \times 10^{6}$ pessoas ano ${ }^{-1}$ poderão ser servidas, respectivamente, pela energia produzida.

Segundo Zylberztajn \& Coelho (1992), citados por Faccenda \& Souza (1998), a conservação de energia, juntamente com o uso equilibrado da biomassa, pode tornar-se a melhor opção, em termos de impactos ambientais vinculados à emissão de $\mathrm{CO}_{2}$ e de enxofre, devido a recaptura do carbono no processo de replantio da biomassa anteriormente usada e da ausência de enxofre na mesma.

Luca (2002) apresenta dados indicando taxas de seqüestro de carbono na camada $0-5 \mathrm{~cm}$ do solo para a cana crua variando de 0,78 tha. ano em LR a 0,24 tha.ano em LVa, justificando essa variação com a textura desta camada do solo.

Assim, a ausência da queima pode vir a proporcionar um atrativo extra nas negociações referentes ao Protocolo de Quioto e ao incipiente, mas promissor, mercado de carbono, que segundo Manfrinato (2002), deve remunerar em torno de US\$ 7,00 por tonelada de carbono efetivamente seqüestrado.

Porém, a diminuição da queima da palha da cana-de-açúcar exige o desenvolvimento de políticas realistas e mecanismos que estimulem os pequenos e médios produtores à colheita de cana crua, reciclando e aproveitando a palha para a produção de energia, propiciando a manutenção da estrutura física do solo, e facilitando a participação no mercado de carbono. 


\section{5 Áreas de Preservação Permanente-APPs}

\subsubsection{Criação de mata ciliar, a preservação dos mananciais e a Constituição Federal}

Conforme descreve Lima (1989), a expressão "área ripária", ou "área ciliar", tem sido utilizada por vários autores para caracterizar tanto a porção do terreno que inclui a ribanceira do rio propriamente dita, como também a planície de inundação, com suas condições edáficas próprias e a vegetação que ai ocorre (a mata ripária ou ciliar). Portanto, o conjunto formado pela área, pela mata e a vegetação associada, pelo piso florestal e as interações com o meio, poderia ser chamado de ecossistema ripário.

Segundo Corbetti \& Lynch², citados por Lima (1989), as áreas ripárias são sistemas que funcionam como reguladores do fluxo de água, sedimentos e nutrientes entre os terrenos mais altos da bacia hidrográfica e o ecossistema. Desta forma, atuam como filtro ou como um "sistema tampão", o qual se encontra situado justamente entre as partes mais altas da bacia hidrográfica, desenvolvidas pelo homem para a agricultura e urbanização, e a rede de drenagem desta, onde se encontra o recurso natural mais importante do ponto de vista do suporte da vida, que é a água.

Segundo Lima (1989), o ecossistema ripário desempenha sua função hidrológica através de algumas formas principais: i) estabilização dessa área crítica que são as ribanceiras do rio, pelo desenvolvimento e manutenção de um emaranhado radicular; ii) como tampão e filtro entre os terrenos mais altos e o ecossistema aquático, participa do controle do ciclo de nutrientes na bacia hidrográfica, através de ação tanto no escoamento superficial, quanto na absorção de nutrientes do escoamento superficial pela vegetação ciliar; iii) pela

2 CORBETT, E.S; LYNCH, J.A. Management of striamside zones on municipal water-shieds. In: ESTADOS UNIDOS. Departament of Agriculture. Riparian ecosistem and their management. Washington: USDA, Forest Service,1985. p. 187-190. (General Technical Report, RM-120). 
diminuição e filtragem do escoamento superficial, impede ou dificulta o carrámento de sedimentos para o sistema aquático, contribuindo desta forma, para a manutenção da qualidade da água nas bacias hidrográficas; iv) pela sua integração com a superfície da água, proporciona cobertura e alimentação para peixes e outros componentes da fauna aquática; v) pela mesma razão, intercepta e absorve radiação solar, contribuindo para a estabilidade térmica dos pequenos cursos d'água.

A mata ciliar, no ato de sua instituição e ou de sua implantação, não foi objeto de previsão da Constituição Federal (Machado, 1989). Portanto, para esta finalidade, a argumentação do autor é de que se deve aplicar o que já dispõe ou vier a dispor a legislação ordinária.

Conforme definição de Machado (1989), referindo-se à mata ciliar, só há um tipo de criação desse tipo de vegetação, que é a pertinente ao próprio Código Florestal, sendo:

“(..) a mata ciliar é aquela que existe às margens dos cursos d'água, ou inexistindo, deva existir nessas margens, ao redor das lagoas, lagos, reservatórios de água naturais ou artificiais, nas nascentes. A mata ciliar, como todos sabem, está relacionada com a água e a fauna".

A existência de uma mata ciliar, ou a obrigatoriedade de sua implantação independe da vontade do proprietário do terreno ribeirinho (fosse ele o próprio Poder Público ou o particular) e não depende a presença dessa mata de um ato expresso de um órgão da Administração Pública. O Código Florestal de 1965 foi sábio em instituir essas matas só pelo simples ato da promulgação do próprio código. Evidentemente o código não faria o milagre de criar as matas, mas de torná-las necessárias do ponto de vista da lei. Incumbia e continua sendo do dever da Administração Pública, paga também para esse fim, como de todos nós exigir, pelos meios legais previstos, a obediência à lei (...)" (Machado, 2002). 
2.6 Diagnóstico das UPAs do município de Piracicaba relacionadas às APPs e RLs

Sparovek et al. (2003) aponta no Plano Diretor Rural do município de Piracicaba que parte da produção de cana-de-açúcar está em áreas inadequadas, a pecuária possui baixos índices de desempenho e há um grande passivo ambiental relacionado a APPs e RLs. Conforme Mapa de Classificação de Uso do Solo, destacado pela Figura 4, o município está assim distribuído: $46 \%$ cana-de-açúcar, $25 \%$ pastagem, $20 \%$ florestas, $6 \%$ urbano, $3 \%$ água e $1 \%$ outro.

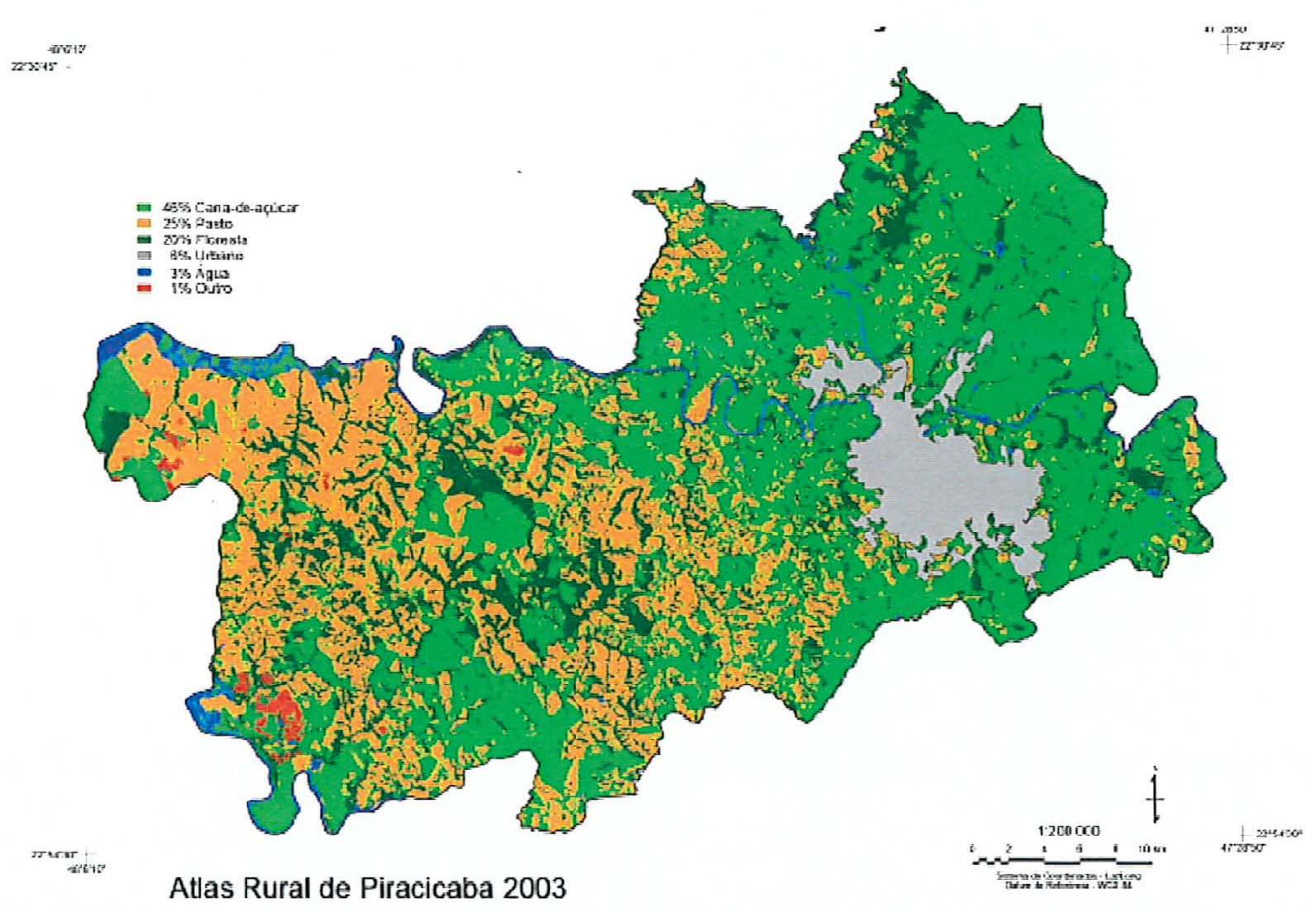

Figura 4 - Classificação do uso da terra do município de piracicaba, conforme apresentado no Plano Diretor Rural de 2003 
Conforme Sparovek (2003) falta recuperar a cobertura florestal em aproximadamente $20 \%$ do território municipal, significando $20 \%$ da área total do município. Portanto, a dimensão do passivo ambiental de Piracicaba não permite uma solução rápida e é necessário pactuar uma ação de longo prazo para garantir a sua continuidade. Para tanto, sugere que devem ser buscadas soluções técnicas realistas, eficientes e viáveis; sensibilização do ministério público e dos proprietários das áreas em situação irregular para pactuarem uma solução; procura de estratégia de financiamento das ações que seja viável e justa. O diagnóstico apresentado foi fiel à sua proposta, porém, há necessidade de continuidade do levantamento de forma mais bem detalhada de cada UPA, tanto separadamente como por microbacia.

Como diretrizes, Sparovek (2003) enfoca que a vocação de Piracicaba é a produção de cana-de-açúcar e isto não deve se modificar, mas falta direcionar melhor alguns pontos importantes relacionados à produção, tais como: a) centrar mais a gestão do negócio no produtor, b) melhorar a adequação às exigências ambientais e demandas sociais relacionadas à queima, relação de trabalho e retorno social da produção, c) diversificar mais a cadeia produtiva da cana-de-açúcar no sentido de fomentar a produção de produtos que são possiveis de serem manufaturados pelos produtores, como açúcar orgânico e mascavo, rapadura, cachaça, d) diversificação empresarial pelo incentivo a novas empresas, sejam elas grandes ou pequenas.

O diagnóstico por meio do Levantamento Conjuntural Socioeconômico, realizado por Bovi et al. (2001), na Bacia do Ribeirão dos Marins, apresenta maior nivel de detalhes. Este relatório apresenta uma caracterização ampla e geral desta Microbacia, trazendo dados relacionados ao clima, solos, recursos hídricos, exploração agrícola e eficiência de exploração, riscos do uso e meio ambiente, mapeamento detalhado de cada UPA, número de propriedades, estradas, estrutura fundiária, relação dos produtores e caracterização socioeconômica. Com esses dados foram identificados, priorizados e feitas propostas de soluções aos problemas. Obteve-se então, um Quadro de Metas 
com a descrição dos problemas e indicadores por componentes, os recursos necessários, órgãos financiadores, entidades participantes, qualificação dos profissionais, estratégia de execução do plano e cronograma fisico de execução. No entanto, deve-se levar em consideração que o custo de um projeto desta natureza é determinante e há necessidade de se trabalhar muito bem todos os elementos envolvidos no sistema para que haja continuidade dos programas ambientais.

\subsection{Alternativas de uso em áreas com restrição à cultura da cana-de- açúcar}

As alternativas sugeridas são aplicáveis somente em locais fora das APPs, pois estas não são passiveis de quaisquer tipo de uso, sendo que nas RLs é permitido um manejo sustentável. Porém, as alternativas sugeridas são passiveis de serem implantadas, mediante estudo de viabilidades, em áreas com declividade acima de $12 \%$ ou que não ofereçam possibilidade de colheita mecanizada, áreas de baixa produtividade, degradadas e restrição total à queima da palha para efeito de colheita.

\subsubsection{Utilização do Sistema Agroflorestal - SAF-CANA}

Neste cenário fica claro que as culturas perenes seriam as mais apropriadas para participarem dos sistemas de produção a serem implantados, pela sua capacidade de preservação do solo e pela adaptação às condições de relevo regional. Estas culturas perenes poderiam ser associadas a culturas anuais, em sistemas agroflorestais, ampliando a diversificação agrícola e propiciando retorno econômico mais rápido. Tais sistemas de produção incluem a adaptação do sistema convencional de produção da cana-de-açúcar para 
consorciação ou a substituição da cana por culturas perenes intercaladas ou não.

O estudo do SAF é de grande complexidade e de natureza interdisciplinar, o que dificulta o desenvolvimento de modelos que vão aos poucos sendo montados, identificando pontos que precisam ser estudados. Desta maneira, a modelagem pode ser vista como peça-chave para determinação e coordenação de estudos experimentais, baseada em processos (Sá, 1994).

Bernardes et al. (1998) propôs a realização de estudo com enfoque multiinstitucional entre a AFOCAPI, $\mathrm{CATI}^{3}$, ESALQ/USP, IAC ${ }^{4}$ e SEMA5/PMPiracicaba, combinando pesquisa acadêmica tradicional com participação contínua de pequenos produtores e instituições de assistência técnica e extensão rural no processo de decisão e áreas de demonstração em escala operacional. O objetivo básico do estudo seria identificar sistemas de produção agroflorestais para áreas inaptas à produção de cana-de-açúcar sem queima (SAF-Cana) e que pudessem atender às seguintes premissas: 1) Adequação à legislação ambiental e que promovam efetivamente melhorias ao ambiente e à conservação do solo; 2) Aceitação cultural pelos pequenos produtores tradicionais de cana-de-açúcar; 3) Promoção da melhoria de oferta e fixação da mão-de-obra na cadeia produtiva; 4) Receita operacional líquida similar àquela da cana-de-açúcar, situada em torno de US\$ 450,00/ha ano (AGRIANUAL, 1997); 5) Mercado seguro e possibilidade de beneficiamento e verticalização ou de comercialização local de seus produtos.

Os sistemas agroflorestais (SAFs) apresentam potencial para a manutenção a atividade agrícola na região de Piracicaba, principalmente à cultura da cana-de-açúcar, o que confere maior sustentabilidade ao setor sucroalcooleiro.

\footnotetext{
${ }^{3}$ Coordenadoria de Assistência Técnica Integral - CATI, órgão da Secretaria Estadual de Agricultura e Abastecimento.

${ }^{4}$ Instituto Agronômico de Campinas

${ }^{5}$ Secretaria Municipal de Agricultura e Abastecimento de Piracicaba.
} 
Migoni-Segovia (2004) verificou que há desconhecimento sobre os SAFs por parte dos Fornecedores de cana, porém, quando são orientados sobre as vantagens desses sistemas demonstram interesse pelas possibilidades de melhor aproveitamento das áreas declivosas utilizando os SAFs. Demonstra também não haver, por parte dos Fornecedores, resistência natural às mudanças tecnológicas. Porém há entraves para a adoção destes sistemas, não inerentes aos Fornecedores, mas sim devido às características da própria tecnologia e sua adaptabilidade às condições locais, a segurança do mercado para os produtos e a falta de um programa oficial de assistência técnica. Constatou-se ainda que os Fornecedores, não sendo contrários às inovações tecnológicas, podem investir, desde que as alternativas tecnológicas sejam rentáveis. Porém, estes têm aversão ao risco financeiro para investimentos em longo prazo, como é o caso dos SAFs. Dessa forma, o principal impedimento para a adoção dos SAFs é a ausência de comprovação concreta das vantagens agronômicas e econômicas desses sistemas.

O trabalho de Migoni-Segovia (2004) é interessante e serve como base para o trabalho multi-institucional já iniciado por Bernardes et al. (1997). Porém, há necessidade de maior especificidade e detalhamento por meio da implantação de um projeto piloto, onde possivelmente poderia haver um acompanhamento prático, mensurando-se os resultados e determinando maior segurança para a aplicação econômica destes sistemas. É demonstrado ainda que, a implantação dos SAFs implica em modificações no sistema de produção de monocultivo que é utilizado no setor canavieiro, e neste sentido, para a implementação de novos sistemas produtivos, alguns pontos devem ser trabalhados, tais como: identificar o nível e o perfil tecnológico e as práticas em uso pelos Fornecedores, diagnosticar o nivel de conhecimento das exigências da legislação ambiental para o setor sucroalcooleiro, categorizar e dimensionar os entraves para a adoção dos SAFs.

Pinto (2002) utilizou modelos de simulação para avaliar a produção de cana-de-açúcar em SAFs com seringueira e eucalipto. Observou que há 
possibilidade de se cultivar cana nesses sistemas. Água e luz são fatores limitantes para a cultura e há aumento de competição de acordo com o crescimento das árvores. Porém o SAF cana-de-açúcar $X$ eucalipto demonstrou produção semelhante ao monocultivo de cada espécie. Os modelos permitiram avaliar os SAFs e orientar experimentos, no entanto há necessidade de instalação de experimentos de campo para obtenção de resultados que possam subsidiar avaliações mais precisas, tanto agronômicas quanto econômicas.

Segundo Pinto et al. (2001), a adoção de Sistemas Agroflorestais nas regiões canavieiras depende da simplicidade na instalação em sistemas flexiveis e no manejo para os Fornecedores. A identificação de Fornecedores inovadores e destacados seria o primeiro passo no processo de pesquisa e difusão agroflorestal no setor canavieiro de estado de São Paulo.

\subsubsection{Utilização de reflorestamento: Pólo Industrial de Base Florestal}

Piracicaba é um município carente na produção de madeira, seja para a geração de energia, utilização em olarias e na panificação, como também na utilização em moirões e postes, madeira para indústria moveleira, fornecimento para a indústria de papel e celulose (Farhat, 2003).

Conforme IPEF(2004) a região de Piracicaba possui um potencial estratégico e utiliza a sua área agrícola de forma extensiva, mesmo assim o cultivo de florestas implantadas resume-se a algumas áreas marginais de pequenas propriedades. Porém, mais recentemente, as grandes empresas do setor de papel e celulose investiram em plantios e em áreas arrendadas.

Segundo IPEF(2004), devido à limitação em mecanizar a colheita e as restrições legais à queima da palha de cana-de-açúcar no município de Piracicaba, muitos locais onde se planta a cana-de-açúcar deverão substituí-la por outras culturas em função destes fatores de impedimento. A implantação de florestas cultivadas tem um grande potencial nestas áreas. Entretanto, essa 
substituição esbarra na competição com outras culturas potenciais e também no retorno de longo prazo do investimento aplicado.

$O$ incentivo tecnológico, financeiro e de investimentos poderá ser um fator de indução para que a região e o município se transformem num Pólo Econômico Florestal, proporcionando mais opções locais de integração entre a agricultura e o setor industrial, especialmente o de base florestal.

O conceito de Pólo Econômico Florestal tem por objetivo criar condições para produzir e industrializar produtos de origem florestal a partir de matériaprima proveniente de cultivos realizados segundo preceitos econômicos, sociais e ambientais adequados, contribuindo para o desenvolvimento sócio-econômico do município de Piracicaba, IPEF (2004).

A implantação de áreas florestais esbarra em uma questão importante, que é o impacto com relação aos investimentos e o longo prazo demandado para o retorno financeiro do empreendimento. No entanto, para minimizar custos propõe-se também a produção em sistema agrosilvopastoril, consorciando nas fases iniciais do plantio, o pastoreio. Esta atividade permite a geração de receitas anuais intermediárias.

De acordo com AFOCAPI (2004), há um convênio entre a Associação dos Fornecedores de Cana de Piracicaba, a COPLACANA e o Instituto de Pesquisas e Estudos Florestais - IPEF/ESALQ-USP, com apoio da Prefeitura Municipal de Piracicaba, para a implantação do Pólo Florestal em Piracicaba, o que caracteriza um esforço multi-institucional. A implantação de um projeto desta natureza vem sendo estudada há bastante tempo por pesquisadores do IPEF.

Conforme AFOCAPI (2004) um plano de ação foi apresentado e referendado pelas entidades envolvidas. Consta desse plano de ação a instalação de um Projeto Piloto com quatro fases. A primeira fase é um campo com o TUME de 32 espécies, onde o eucalipto é a principal espécie utilizada na Estação Experimental AFOCAPI, sendo que as outras três fases são planejadas para UPAs de produtores rurais. 
O objetivo das áreas piloto é apresentar aos produtores uma alternativa de utilização de locais com restrições à cultura da cana-de-açúcar.

\subsubsection{Sistemas de produção de oleaginosas no município de Piracicaba, com ênfase para a soja \& cana-de-açúcar}

Há necessidade de mudanças nos sistemas de produção agrícola da região de Piracicaba. Uma das formas de manter a economia agrícola regional é o planejamento das atividades envolvendo a diversificação de atividades e verticalização da produção (Bernardes et al., 1998).

Conforme Farhat ${ }^{6}$, os sistemas de produção utilizando oleaginosas no município de Piracicaba dão bons resultados. Alguns produtores estão utilizando a cultura em propriedades marginais. As mais utilizadas são aquelas que estão próximas às áreas urbanizadas, ou seja, a região do entorno imediato, sendo destinadas à cultura da soja em rotação, principalmente, com o triticali. Para estas as áreas marginais e as de pastagens degradadas seria interessante o fomento ao plantio direto, pois apresentam potencial para produção de grãos, e também a utilização da soja nas áreas de reforma de canaviais para cana de 18 meses. Porém, as áreas utilizadas para este fim e a produção alcançada ainda são pequenas. No entanto, algumas mudanças poderão acontecer em função das restrições impostas pela legislação de queima da palha de cana para efeito de colheita.

Segundo Silva et al. ${ }^{7}$ para viabilizar o sistema de plantio direto na palha é preciso capacitar maior número de técnicos da área de assistência técnica e

6 FARHAT, M. Utilização de plantas oleaginosas em sistemas de produção com ênfase para a cana de 18 meses (Saccharum spp.). Piracicaba, 2003. 46p. Monografia (Pós-Graduação) Escola Superior de Agricultura "Luiz de Queiroz", Universidade de São Paulo.

7 SILVA, A.V.; VOLL, C.E., VALLE, J.N.D.; BREGAGNOLI, M.; FARHAT, M.; SCARPARI, M.S.; BETTINI, P.C.; VIEIRA JUNIOR, P.A.; CATO, S.C.A. Soja em plantio direto (Glycine max (L) Merrill). Piracicaba, 2003. 96p. Monografia (Pós-Graduação) - Escola Superior de Agricultura "Luiz de Queiroz" - Universidade de São Paulo 
extensão rural para levar as informações da pesquisa aos agricultores, fazendo com que todos se conscientizem sobre a importância da cobertura permanente do solo, pois ela mantém e melhora seus atributos físicos, químicos e biológicos. Observa ainda que a biologia existente no plantio direto, pela presença de diversos microrganismos que formam a micro e macrofauna, resulta na obtenção de um ambiente equilibrado e "auto-sustentável", proporcionando à cultura da soja ou outras, um habitat favorável para o seu desenvolvimento com alta produtividade. Além disso, há outros benefícios que podem ser obtidos com a rotação de culturas em plantio direto, como a manutenção da fertilidade do solo com maior aproveitamento e reciclagem de nutrientes, economia de produtos fitossanitários, entre outros, possibilitando maior retorno econômico.

Segundo Mascarenhas \& Tanaka (2000), o emprego de espécies leguminosas como adubo verde resulta em significativa melhoria nas caracteristicas químicas, físicas e biológicas do solo, com aumento da retenção de nutrientes, o controle de plantas voluntárias, de parasitas e da erosão do solo.

Estudo realizado por Mascarenhas \& Tanaka (2000) com o objetivo de quantificar o efeito da adubação verde com algumas espécies de leguminosas, dentre elas a soja, sobre o rendimento físico e econômico na produção da canade-açúcar, mostrou aumentos na produção de cana e açúcar de $16 \%$ a $47 \%$, representando um aumento de até cinco toneladas de açúcar por hectare. No entanto, embora tenha havido aumentos expressivos na produção de cana e de açúcar pela rotação com crotalária e mucuna preta, o cultivo da soja na renovação do canavial, apesar de propiciar menores produções de cana-deaçúcar, permitiu obter um retorno econômico muito maior devido à renda obtida com os grãos da oleaginosa.

Segundo Mascarenhas et al. (2003) experimentos demonstraram não ser necessário a aplicação de nitrogênio em cobertura em lavoura de cana-deaçúcar plantada em sistema de plantio direto, após um ou dois anos de cultivo 
com soja. A produtividade foi estatisticamente a mesma em tratamentos pousio $+\mathrm{N}$ e após uma safra de soja, sendo que essa tendência também foi observada no rendimento de açúcar em tha.

Mascarenhas et al. (2003) conclui que, além da economia de herbicidas, a produção de soja gera uma receita obtida com a venda de grãos, o que seria suficiente para cobrir custo da implantação da lavoura de cana-de-açúcar. Porém, na prática, o produtor deve optar pelo plantio da cana-de-açúcar após um ou dois anos com soja, observando os preços de ambas as culturas. Outros resultados relevantes da pesquisa relatam a possibilidade de redução parcial do custo de produção, em função da diminuição ou até mesmo da eliminação da adubação mineral nitrogenada, e conseqüente otimização dos rendimentos da lavoura da cana-de-açúcar, somente com a utilização da soja no sistema de produção. Além disso, a preservação ambiental com a redução da poluição do solo pelos adubos minerais nitrogenados e a contribuição para a economia do Pais em função da redução, tanto da importação quanto da quantidade de petróleo despendido na produção de adubos nitrogenados.

Farhat (2003) relata que vários benefícios poderiam ocorrer em conseqüência da adoção deste sistema, além dos aspectos agronômicos, tais como: o aumento da produção de sementes e grãos, a diversificação de culturas, estímulo ao Plantio Direto, investimentos em plantio, investimentos em máquinas e implementos, diminuição de custos de implantação de lavoura de cana-de-açúcar e aumento das áreas de renovação com cana de 18 meses, fortalecimento da agroindústria regional, do cooperativismo e do associativismo, aumento de mão-de-obra e de profissionais capacitados, aumento de postos de trabalho, aumento de renda para o agricultor e trabalhadores rurais, melhorias nas estruturas para armazenamento e financiamentos para estocagem, economia de energia e de combustivel, mais impostos e divisas para o município, aumento na comercialização de insumos e utilização da culturas em substituição da cana-de-açúcar em áreas com total restrição à queima da palha de cana. 
A implantação de uma nova cultura também depende de uma logística de escoamento da produção.

Segundo Pagot (2000) referindo-se aos produtores de soja das regiões centro-oeste e Norte do Brasil, embora com produtividades que vão de 52 a 70 sacas por hectare, os produtores arcam com elevados preços de frete para transportar via rodoviária as produções até os portos de Santos (SP) e Paranaguá (PR), com distâncias médias de 2000 quilômetros. Na safra o valor do frete chega a custar em média US\$ 95,00 a US\$ 115,00 por tonelada transportada.

Piracicaba está bem localizada e favorecida com relação à logística de transporte pela malha rodoviária, proximidade da indústria de transformação e proximidade do porto de Santos. 


\section{METODOLOGIA}

\section{1 Área de estudo}

O município de Piracicaba situa-se no Estado de São Paulo e sua sede localiza-se nas coordenadas S $22^{\circ} 42^{\prime} 30^{\prime \prime}$, W $47^{\circ} 38^{\prime} 01^{\prime \prime}$ e altitude média de 554 $\mathrm{m}$. Ocupa uma área de $1.312,30 \mathrm{~km}^{2}$ com uma área rural de $1.154 \mathrm{~km}^{2}$ que correspondem a aproximadamente $115 \mathrm{mil}$ ha, dos quais 84 mil utilizados para a agricultura, com ênfase nas áreas ocupadas com cana-de-açúcar de Fornecedores.

\subsection{Banco de dados e cruzamento das informações: Consultas e Buscas}

Foram utilizadas informações do meio físico de Piracicaba, provenientes de 2 bancos de dados: 1) banco de dados que contém informações tabuladas e mapas georreferenciados, oriundo da AFOCAPI sobre as áreas com cana-deaçúcar dos Fornecedores, número de UPAs, número de módulos rurais por UPA e o número de Fornecedores. Em parte, o georeferenciamento das áreas foi feito em conjunto com as usinas Costa 1Pinto e Santa Helena, ambas do Grupo COSAN; usina Iracema do grupo São Martinho; 2) o banco de dados da do Departamento de Solos e Nutrição de Plantas da Escola Superior de Agricultura "Luiz de Queiroz" - ESALQ/USP.

As bases de dados foram relacionadas através de operadores de banco de dados em ambiente Microsoft ${ }^{\circledR}$ Office 2000 e, quando georreferenciadas, integradas espacialmente através de ferramentas de geoprocessamento 
(sobreposição de temas, análise de imagens e geração de buffers) utilizando o Sistema de Informações Geográficas (SIG) TNT mips ${ }^{\circledR}$. Especialmente na estimativa das APPs, foi gerada, a partir da rede de drenagem (PDR Piracicaba, 2004), uma zona eqüidistante das margens 30,50 ou 100 metros, conforme a exigência da legislação. A intersecção espacial entre as áreas dos Fornecedores de cana, as áreas de restrição à queima do entorno imediato urbano e as APPs, possibilitou a totalização dos dados e geração de cenários de adequação à legislação.

\subsection{Caracterização quantitativa dos Fornecedores de cana}

Foram Agregadas as informações para facilitar o entendimento de como a legislação ambiental afetaria cada classe de produtores em termos numéricos da área de produção.

A caracterização foi feita a partir do banco de dados estatísticos da AFOCAPI, (2005). A partir desses dados foram avaliados os seguintes parâmetros: 1) a lista de produtores; 2) a separação por classes de produção; 3) separação por número de UPAs; 4) a separação por número de módulos rurais utilizados por Fornecedor; e 5) por cana produzida e entregue nas usinas. Esses dados foram tabulados e agregados por classe utilizando os dados em ambiente Microsoft Office Excel 2000.

A agregação dos dados nos permite traçar comentários sobre a resposta deles à essa legislação e demonstrar o impacto por Fornecedor.

A separação por classe apresenta similaridade em produção, módulos rurais, número de UPAs sobre posse de cada Fornecedor. 


\subsection{Caracterização quantitativa das UPAs}

As UPAs são caracterizadas porque é sobre elas que se aplica a legislação, porém quem se obriga à essas ações e cumprir a legislação, são os Fornecedores.

As UPAs foram caracterizadas tanto nos aspectos quantitativos como área de produção e tamanho, quanto no aspecto de posicionamento na paisagem uma vez que esses dois aspectos são importantes para entender o efeito da legislação ambiental.

A caracterização quantitativa das UPAs foi feita a partir do banco de dados estatísticos da AFOCAPI, (2005) sob dois aspectos: 1) inserção da UPA na região do Entorno Imediato - 1000 metros da área urbanizada; 2) inserção da UPA em APP; e 3) com relação à Reserva Legal, segundo a legislação, não há possibilidade de exclusão de quaisquer UPAs, pois, todas estão obrigadas a se ajustarem.

\subsubsection{Número de UPAs que devem se adequar, reflexos na produção e na mão-de-obra}

Foram quantificadas as UPAs que deverão se adequar quanto a diminuição de queima da palha da cana na região do entorno imediato contando-se $1000 \mathrm{~m}$ a partir do final da área urbanizada; quanto significa de APPs que estão sendo utilizadas para o cultivo cana-de-açúcar; quanto de Reserva Legal. Também foi levantado quanto da produção deverá ser comprometida e deixará de produzir cana, e os reflexos sobre a mão-de-obra. $\mathrm{O}$ número de ocupados na área agrícola do setor canavieiro de Piracicaba, em função da integral aplicação da legislação ambiental foi estimado considerando um índice de emprego de EHA/ha que foi multiplicado pela área de cana-deaçúcar que deixará de ser plantada e cultivada, pela mesma razão. 


\section{RESULTADOS}

\subsection{Perfil dos Fornecedores de Cana do município de Piracicaba}

Os resultados quanto ao tamanho das áreas utilizadas com cana-deaçúcar, à produção e as características dos Fornecedores do município de Piracicaba estão apresentados nas Tabelas 22, 23 e 24 e nas Figuras 5, 6 e 7.

O levantamento mostrou que as UPAs utilizadas pelos Fornecedores têm características relativas à extensão de área, que eram previsiveis já no século XIX, quando a partição das áreas agrícolas tomava os rumos para a formação de pequenas propriedades.

As UPAs do município que estão sob o domínio dos Fornecedores têm características diversas e são apresentadas de forma a subsidiar discussões para as questões pertinentes à viabilidade de produção frente às necessidades de adequação ambiental das áreas de produção da cultura de cana-de-açúcar.

O número total de UPAs com produção de cana-de-açúcar foi de 1.040 com os mais diversos potenciais de produção. $\mathrm{Na}$ diversidade de formas de produção, alguns itens são mais relevantes, como o tamanho da área utilizada para a produção, tipo de solo, declividade, tecnologia empregada, formas de sociedade ou parcerias, número de produtores por área, distância da unidade industrial, potencial de mecanização agrícola e de investimento.

A Tabela 22 apresenta o estrato que descreve o peso entregue em $\mathrm{Kg}$, o número de Fornecedores por categoria, o percentual em peso e percentual de fornecimento, e o peso médio entregue de cana-de-açúcar na safra 2004/2005, iniciando com entrega de até $100.000 \mathrm{Kg}$ e terminando em 190.000.000 Kg. Do 
total de Fornecedores apenas 28 produzem acima de $10.000 \mathrm{t}$. Utilizando-se, a média de produtividade aplicada pela ORPLANA, que é de 80 tha, estas UPAs possuem área com cana de 125 ha. A maioria dos Fornecedores é composta por pequenos e médios, obtendo produção abaixo de 3.000 t., ou seja, entre 1.000 e $1.500 \mathrm{t}$, representando $11,3 \%$, com área média variando entre 12,5 ha $\mathrm{e}$ 18,8 ha.

Tabela 22. Estratificação geral dos Fornecedores de cana do municipio de Piracicaba em relação ao peso de cana limitado por faixa de entrega

\begin{tabular}{cccccc}
\hline & PESO & N DE & & & PESO \\
FAIXA DE ENTREGA $(\mathrm{Kg})$ & ENTREGUE $(\mathrm{Kg})$ & FORNEC & F DE FORNEC & PESO \% & MÉDIO/FAIXA \\
\hline 170.000 .001 a 190.000 .000 & 0 & 0 & $0.00 \%$ & $0.00 \%$ & 0 \\
150.000 .001 a 170.000 .000 & 0 & 0 & $0.00 \%$ & $0.00 \%$ & 0 \\
130.000 .001 a 150.000 .000 & 0 & 0 & $0.00 \%$ & $0.00 \%$ & 0 \\
110.000 .001 a 130.000 .000 & 129.307 .730 & 1 & $0.09 \%$ & $6.71 \%$ & 129.307 .730 \\
90.000 .001 a 110.000 .000 & 0 & 0 & $0.00 \%$ & $0.00 \%$ & 0 \\
70.000 .001 a 90.000 .000 & 0 & 0 & $0.00 \%$ & $0.00 \%$ & 0 \\
50.000 .001 a 70.000 .000 & 123.608 .990 & 2 & $0.18 \%$ & $6.41 \%$ & 61.804 .495 \\
40.000 .001 a 50.000 .000 & 0 & 0 & $0.00 \%$ & $0.00 \%$ & 0 \\
30.000 .001 a 40.000 .000 & 0 & 0 & $0.00 \%$ & $0.00 \%$ & 0 \\
20.000 .001 a 30.000 .000 & 102.100 .320 & 4 & $0.36 \%$ & $5.30 \%$ & 25.525 .080 \\
10.000 .001 a 20.000 .000 & 297.840 .154 & 21 & $1.87 \%$ & $15.45 \%$ & 14.182 .864 \\
9.000 .001 a 10.000 .000 & 65.919 .846 & 7 & $0.62 \%$ & $3.42 \%$ & 9.417 .121 \\
8.000 .001 a 9.000 .000 & 24.991 .122 & 3 & $0.27 \%$ & $1.30 \%$ & 8.330 .374 \\
7.000 .001 a 8.000 .000 & 66.505 .395 & 9 & $0.80 \%$ & $3.45 \%$ & 7.389 .488 \\
6.000 .001 a 7.000 .000 & 59.664 .430 & 9 & $0.80 \%$ & $3.10 \%$ & 6.629 .381 \\
5.000 .001 a 6.000 .000 & 75.514 .708 & 14 & $1.25 \%$ & $3.92 \%$ & 5.393 .908 \\
4.500 .001 a 5.000 .000 & 43.190 .096 & 9 & $0.80 \%$ & $2.24 \%$ & 4.798 .900 \\
4.000 .001 a 4.500 .000 & 64.331 .440 & 15 & $1.33 \%$ & $3.34 \%$ & 4.288 .763 \\
3.500 .001 a 4.000 .000 & 64.178 .856 & 17 & $1.51 \%$ & $3.33 \%$ & 3.775 .227
\end{tabular}


Tabela 22. Estratificação geral dos Fornecedores de cana do municipio de Piracicaba em relação ao peso de cana limitado por faixa de entrega (cont.)

\begin{tabular}{|c|c|c|c|c|c|}
\hline FAIXA DE ENTREGA $(\mathrm{Kg})$ & $\begin{array}{c}\text { PESO } \\
\text { ENTREGUE (Kg) }\end{array}$ & $\begin{array}{c}N^{\circ} \mathrm{DE} \\
\text { FORNEC }\end{array}$ & $\%$ DE FORNEC & PESO \% & $\begin{array}{c}\text { PESO } \\
\text { MÉDIO/FAIXA }\end{array}$ \\
\hline 3.000 .001 a 3.500 .000 & 61.696 .509 & 19 & $1.69 \%$ & $3.20 \%$ & 3.247 .185 \\
\hline 2.500 .001 a 3.000 .000 & 71.176 .138 & 26 & $2.31 \%$ & $3.69 \%$ & 2.737 .544 \\
\hline 2.000 .001 a 2.500 .000 & 116.799 .401 & 53 & $4.72 \%$ & $6.06 \%$ & 2.203 .762 \\
\hline 1.500 .001 a 2.000 .000 & 117.864 .961 & 67 & $5.96 \%$ & $6.11 \%$ & 1.759 .179 \\
\hline 1.000 .001 a $\quad 1.500 .000$ & 156.864 .901 & 127 & $11.30 \%$ & $8.14 \%$ & 1.235 .157 \\
\hline 900.001 a $\quad 1.000 .000$ & 25.968 .740 & 27 & $2.40 \%$ & $1.35 \%$ & 961.805 \\
\hline 800.001 a $\quad 900.000$ & 42.654 .482 & 50 & $4.45 \%$ & $2.21 \%$ & 853.090 \\
\hline 700.001 a $\quad 800.000$ & 29.909 .208 & 40 & $3.56 \%$ & $1.55 \%$ & 747.730 \\
\hline $600.001 \mathrm{a}$ & 33.337 .565 & 51 & $4.54 \%$ & $1.73 \%$ & 653.678 \\
\hline 500.001 a & 34.169 .795 & 62 & $5.52 \%$ & $1.77 \%$ & 551.126 \\
\hline $400.001 \mathrm{a}$ & 37.276 .005 & 84 & $7.47 \%$ & $1.93 \%$ & 443.762 \\
\hline 300.001 a & 28.369 .766 & 80 & $7.12 \%$ & $1.47 \%$ & 354.622 \\
\hline $200.001 \mathrm{a}$ & 29.615 .219 & 116 & $10.32 \%$ & $1.54 \%$ & 255.304 \\
\hline 100.001 a $\quad 200.000$ & 19.409 .951 & 126 & $11.21 \%$ & $1.01 \%$ & 154.047 \\
\hline até $\quad 100.000$ & 5.219 .740 & 85 & $7.56 \%$ & $0.27 \%$ & 61.409 \\
\hline TOTAL & 1.927 .485 .468 & 1.124 & $100.00 \%$ & $100.00 \%$ & 1.714 .845 \\
\hline
\end{tabular}

Fonte: AFOCAPI, 2005.

De acordo com a AFOCAPI (2005), o número de Fornecedores do município de Piracicaba na safra 2004/05 foi de 852 , dos quais 532 são os responsáveis administrativos pelas UPAs e também representantes de uma família ou de uma sociedade, e 320 são os seus agregados ${ }^{8}$, o quais mantêm alguma forma de sociedade na produção.

${ }^{8}$ Agregados: São os Fornecedores que estão ligados aos Fornecedores principais, podendo ser da mesma familia, herdeiros, sócios, parceiros ou arrendantes. 
$\mathrm{Na}$ Tabela 23 estão considerados os Fornecedores ativos, que são os titulares ou os principais responsáveis pela produção. $A$ área total de produção desses Fornecedores é de 23.156 ha, em um total de 1.040 UPAs, representando produção aproximada de 1,92 milhões toneladas de cana.

Tabela 23. Número de Fornecedores relacionados ao número de UPAs e área de produção

\begin{tabular}{|c|c|c|c|c|c|c|c|}
\hline $\begin{array}{l}\text { NÚM. UPAS I } \\
\text { FORNECEDORES ATIVOS }\end{array}$ & $\begin{array}{c}\text { *FORNECEDORES } \\
\text { ATIVOS }\end{array}$ & $\begin{array}{c}\% \\
\text { FORNECEDORES }\end{array}$ & $\begin{array}{l}\text { AREA } \\
\text { TOTAL }\end{array}$ & $\begin{array}{l}\text { \% ÁREA } \\
\text { TOTAL }\end{array}$ & $\begin{array}{l}\text { AREA } \\
\text { MINIMA }\end{array}$ & $\begin{array}{l}\text { ÁREA } \\
\text { MÁXIMA }\end{array}$ & $\begin{array}{l}\text { AREA MÉDIA I } \\
\text { FUNDO } \\
\end{array}$ \\
\hline 1 UPA & 341 & $64 \%$ & 6536 & $28 \%$ & 0,5 & 643 & 19 \\
\hline 2 UPAs & 89 & $17 \%$ & 4363 & $19 \%$ & 4,5 & 1329 & 49 \\
\hline 3 UPAs & 39 & $7 \%$ & 2648 & $11 \%$ & 7,6 & 229 & 68 \\
\hline 4 UPAs & 18 & $3 \%$ & 1342 & $6 \%$ & 13,5 & 214 & 75 \\
\hline 5 UPAs & 14 & $3 \%$ & 1554 & $7 \%$ & 18 & 311 & 111 \\
\hline 6 UPAs & 11 & $2 \%$ & 1242 & $5 \%$ & 11 & 397 & 113 \\
\hline 7 UPAs & 5 & $1 \%$ & 559 & $2 \%$ & 16 & 318 & 112 \\
\hline 8 UPAs & 5 & $1 \%$ & 1228 & $5 \%$ & 57 & 413 & 246 \\
\hline 9 UPAs & 4 & $1 \%$ & 442 & $2 \%$ & 55 & 227 & 110 \\
\hline 10 UPAs & 1 & $0,2 \%$ & 240 & $1 \%$ & 240 & 240 & 240 \\
\hline $11-23$ UPAs & 5 & $1 \%$ & 3003 & $13 \%$ & 190 & 1520 & 601 \\
\hline TOTAL $\quad \mathbf{1 0 4 0}$ & 532 & $100 \%$ & 23.156 & $100 \%$ & & & \\
\hline
\end{tabular}

* Fornecedores Ativos: são os titulares ou os responsáveis pela produção.

A maioria dos produtores, $88 \%$ do total de 469 , possui até três UPAs, o que corresponde a 13.547 ha e aproximadamente $50 \%$ da área total de produção dos Fornecedores do município.

As Figura 5, 6 e 7 revelam que 341 Fornecedores, $64 \%$ do total, produzem em até uma única UPA. Estes possuem então, entre 0,5 e 643 ha de cana (média de $19 \mathrm{ha}$ ), os quais representam para muitos deles a única fonte de renda. 


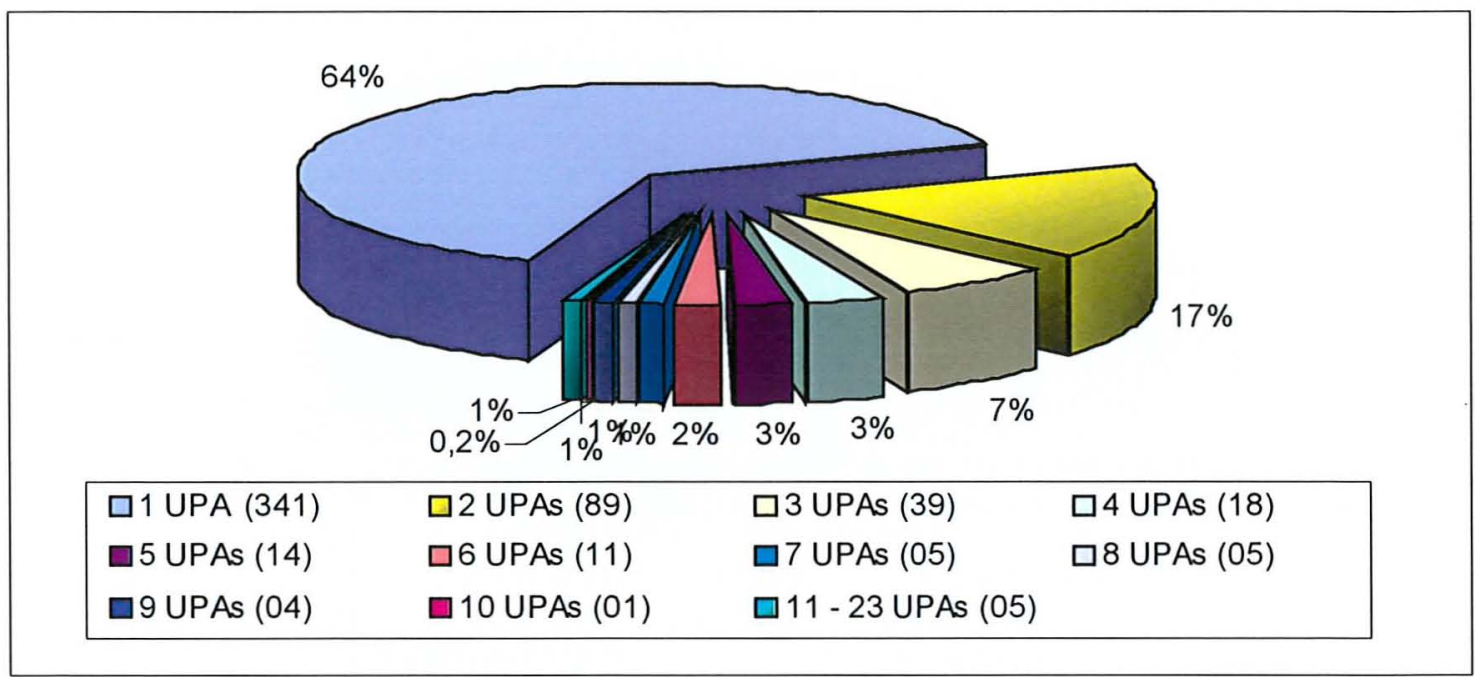

Figura 5 - Estrato do número de UPAs em relação a área de produção dos Fornecedores

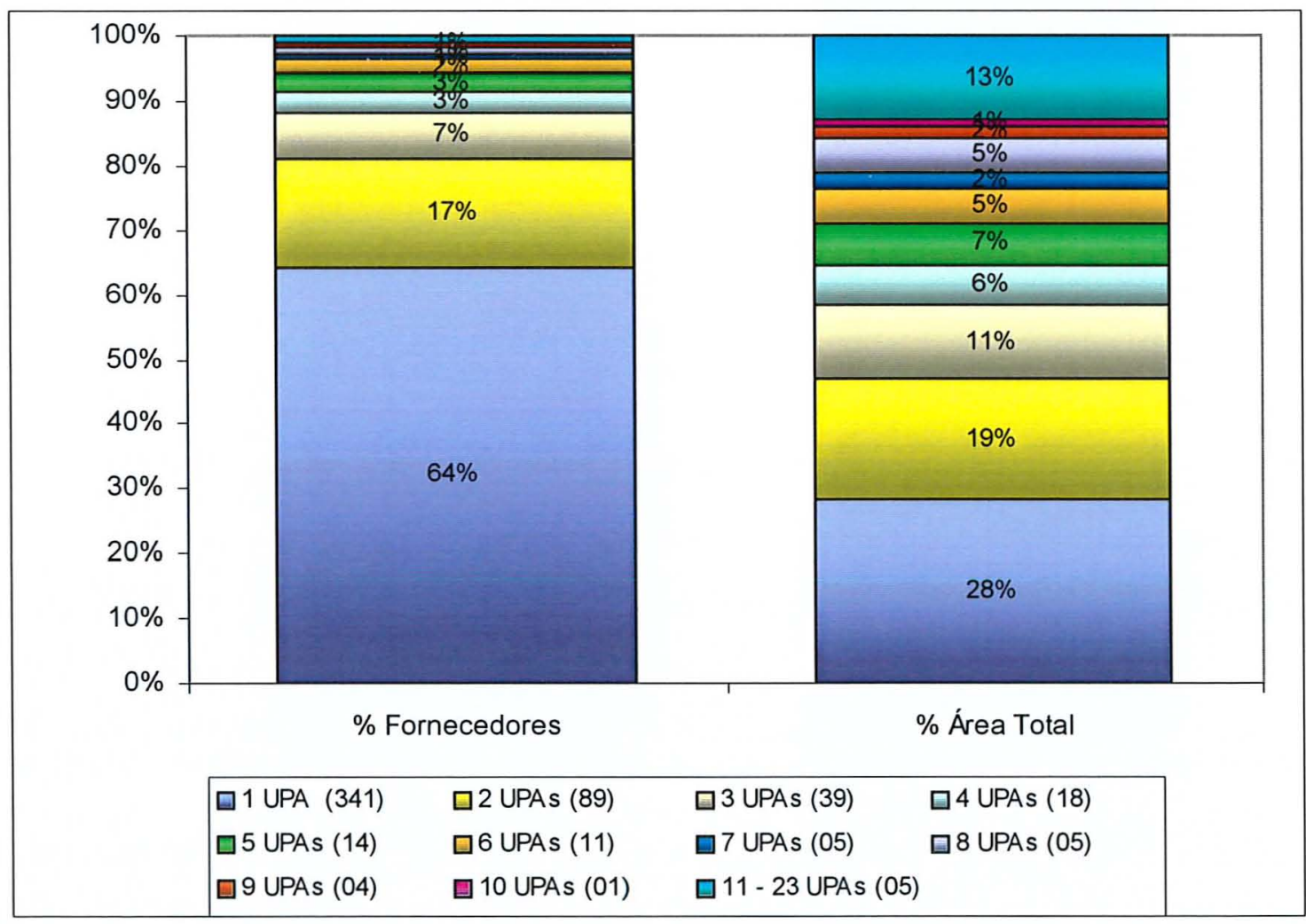

Figura 6 - Percentual das áreas produtivas relacionadas ao percentual de produção 


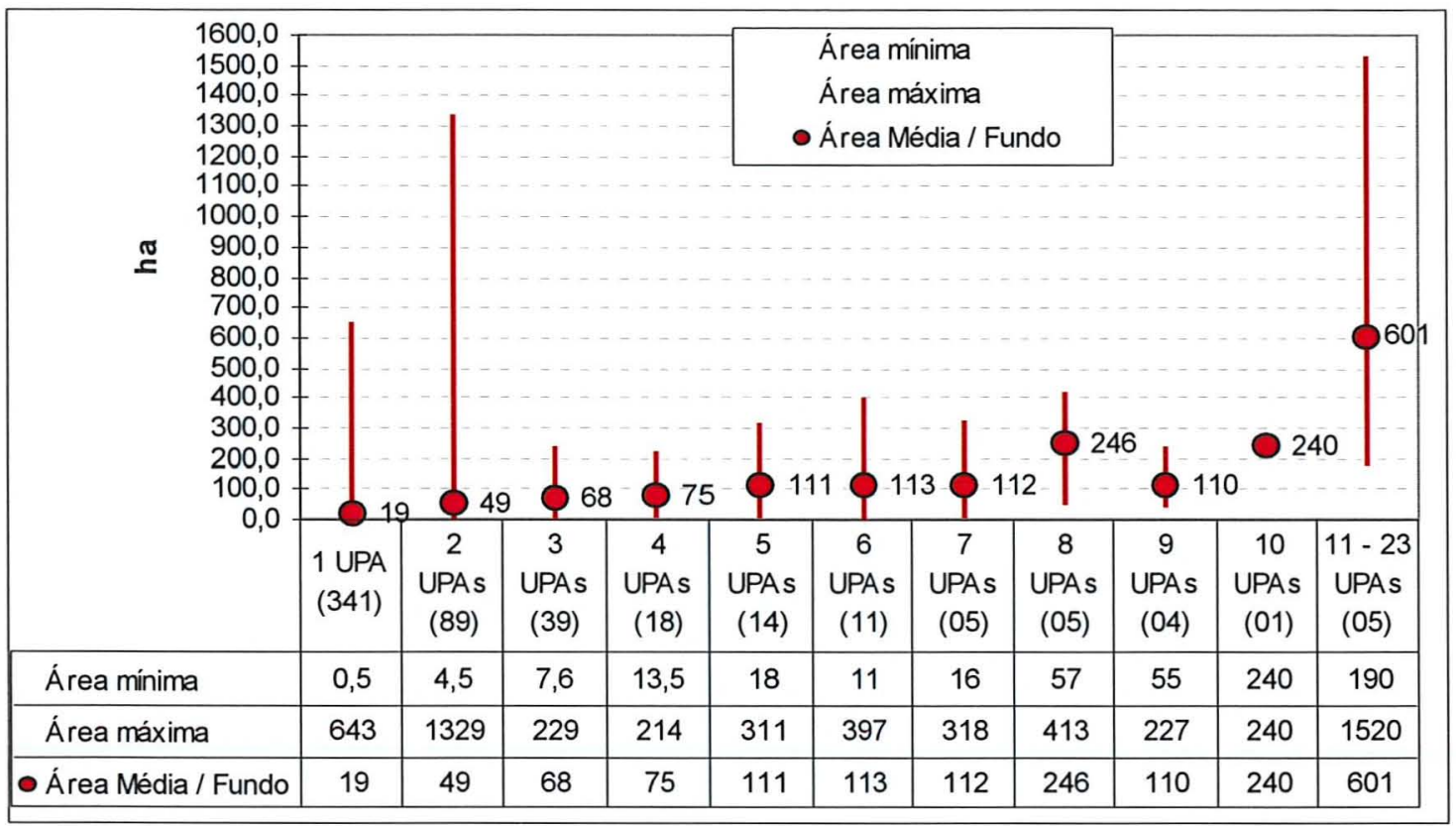

Figura 7 - Estrato das áreas médias por categoria de UPAs e Fornecedores

Tabela 24. Estrato da quantidade de módulos rurais do município de Piracicaba com relação às UPAs

\begin{tabular}{|c|c|c|c|c|}
\hline Número de Módulos Rurais* / UPA & Número de UPAs & $\%$ UPAs & Área & $\%$ Área (ha) \\
\hline até 1 & 442 & $42,4 \%$ & 2.500 & $10,8 \%$ \\
\hline de $>1$ até 2 & 282 & $27,1 \%$ & 4.220 & $18,2 \%$ \\
\hline de $>2$ até 3 & 127 & $12,2 \%$ & 3.224 & $13,9 \%$ \\
\hline de $>3$ até 4 & 59 & $5,7 \%$ & 2.057 & $8,9 \%$ \\
\hline de $>4$ até 5 & 35 & $3,4 \%$ & 1.561 & $6,7 \%$ \\
\hline de $>5$ até 6 & 24 & $2,3 \%$ & 1.302 & $5,6 \%$ \\
\hline de $>6$ até 7 & 17 & $1,6 \%$ & 1.082 & $4,7 \%$ \\
\hline de $>7$ até 8 & 12 & $1,2 \%$ & 885 & $3,8 \%$ \\
\hline de $>8$ até 9 & 10 & $1,0 \%$ & 872 & $3,8 \%$ \\
\hline de $>9$ até 10 & 10 & $1,0 \%$ & 947 & $4,1 \%$ \\
\hline de $>10$ até 15 & 16 & $1,5 \%$ & 1.991 & $8,6 \%$ \\
\hline de $>15$ até 21 & 3 & $0,3 \%$ & 542 & $2,3 \%$ \\
\hline de $>21$ até 61 & 0 & $0,0 \%$ & 0 & $0,0 \%$ \\
\hline de $>61$ até 73 & 3 & $0,3 \%$ & 1.972 & $8,5 \%$ \\
\hline TOTAL & 1040 & $100,0 \%$ & 23.156 & $100 \%$ \\
\hline
\end{tabular}

* 1 (um) módulo rural para o município de Piracicaba = 10 (dez) Hectares. 
A Tabela 24 revela que, considerando-se como pequeno e médio produtor aquele com UPAs com até três módulos rurais, ou seja, com até 30 ha, esse estrato de Fornecedores totaliza $82 \%$ dos casos. A maior parte desses pequenos e médios produtores (442) produz em área correspondente a até um módulo rural, ou seja, em até 10 ha, o que representa $42,4 \%$ do total de áreas de produção. As áreas com até dois módulos rurais somam 282, correspondendo a $27,1 \%$, e com até três módulos 127 , correspondendo a $12,2 \%$ do total. As 189 UPAs restantes correspondem a $18 \%$ do total. Cabe observação de que no presente estrato a quantidade de hectares utilizada por cada produtor pode não ser de uma única UPA. Parte desses produtores possui agregados, ou seja, aqueles que mantêm alguma forma de sociedade na produção, portanto somando um total 852 indivíduos envolvidos diretamente na produção.

\subsection{Perfil das UPAs utilizadas pelos Fornecedores de Cana do município de Piracicaba}

Dados provenientes do banco de dados da AFOCAPI (2004) e aplicados em SIG possibilitam observar alguns pontos de relevância quanto à proibição de queima da palha de cana e APPs. Com relação à Reserva Legal, de acordo com a legislação, todas as UPAs estão obrigadas a se ajustarem tendo $20 \%$ da sua área destinada para esse fim. Com relação às APPs foram avaliadas $67,5 \%$ das UPAs e, nesse contexto, existem atualmente $4 \%$ da área visualizada com cana-de-açúcar para as quais deve haver recomposição. 


\subsubsection{UPAs com restrição total à queima da palha de cana}

Conforme as exigências da legislação, existem algumas situações, onde ocorem áreas com total restrição à queima, porém, para efeito deste trabalho estão sendo usadas somente as áreas do entorno imediato, com distância de $1000 \mathrm{~m}$ da área urbanizada, por serem as localidades de maiores conflitos e/ou entraves para a continuidade da produção de cana-de-açúcar. Não deixando, porém, de elucidar que também existem outras importantes localidades, onde a queima é proibida, porém com um nível de conflitos, podendo-se considerar baixo. Pode perceber na Tabela 25 a área total do entorno imediato, a qual soma aproximadamente $12 \mathrm{mil}$ ha.

Tabela 25. Área aproximada em ha da região do entorno imediato município de Piracicaba, Sede e principais Bairros e/ou Distritos

\begin{tabular}{clc}
\hline MUNICIPIO & \multicolumn{1}{c}{ BAIRRO } & AREA DA FAIXA DE 1000 METROS EM HA. \\
\hline Piracicaba (SEDE) & \multicolumn{1}{c}{} \\
& Anhumas & $6.364,68$ \\
& Artemis/Noiva da Colina & 600,26 \\
& Santa Olimpia/Santana & $1.608,60$ \\
& Tanquinho & 961,11 \\
& Tupi & $1.032,31$ \\
Total & & 505,57 \\
\hline
\end{tabular}

Fonte: AFOCAPI, 2004. 


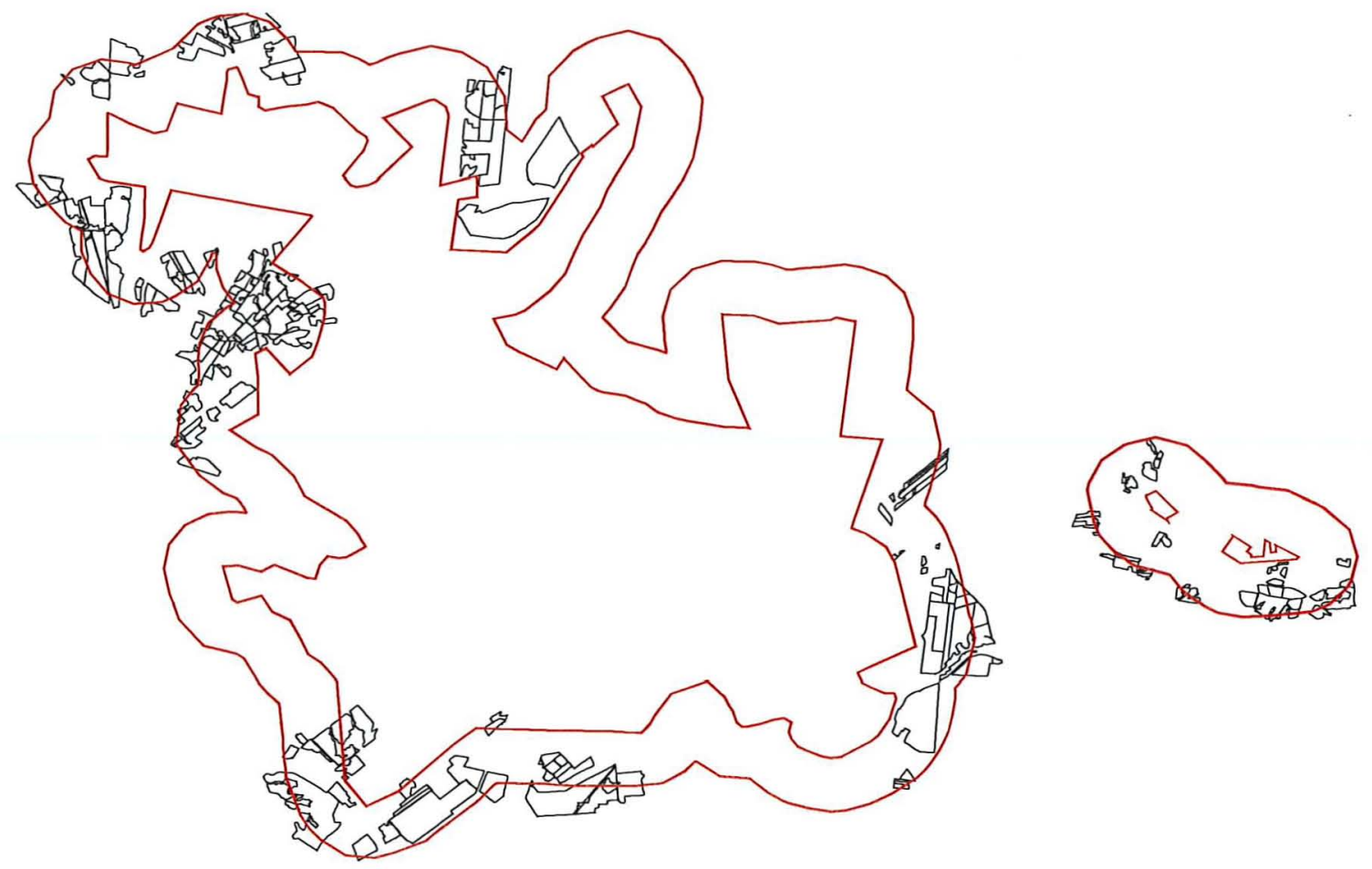

Figura 8 - Área do Entorno imediato do município de Piracicaba com distribuição espacial das UPAs, georreferenciadas com distância de 1.000 metros conforme levantamento realizado pela AFOCAPI, 2005 
Tabela 26. Levantamento das UPAs localizadas na área do entorno imediato de $1.000 \mathrm{~m}$, com restrição total à queima de cana dos municípios de Piracicaba e seus limitrofes área de atuação da AFOCAPI

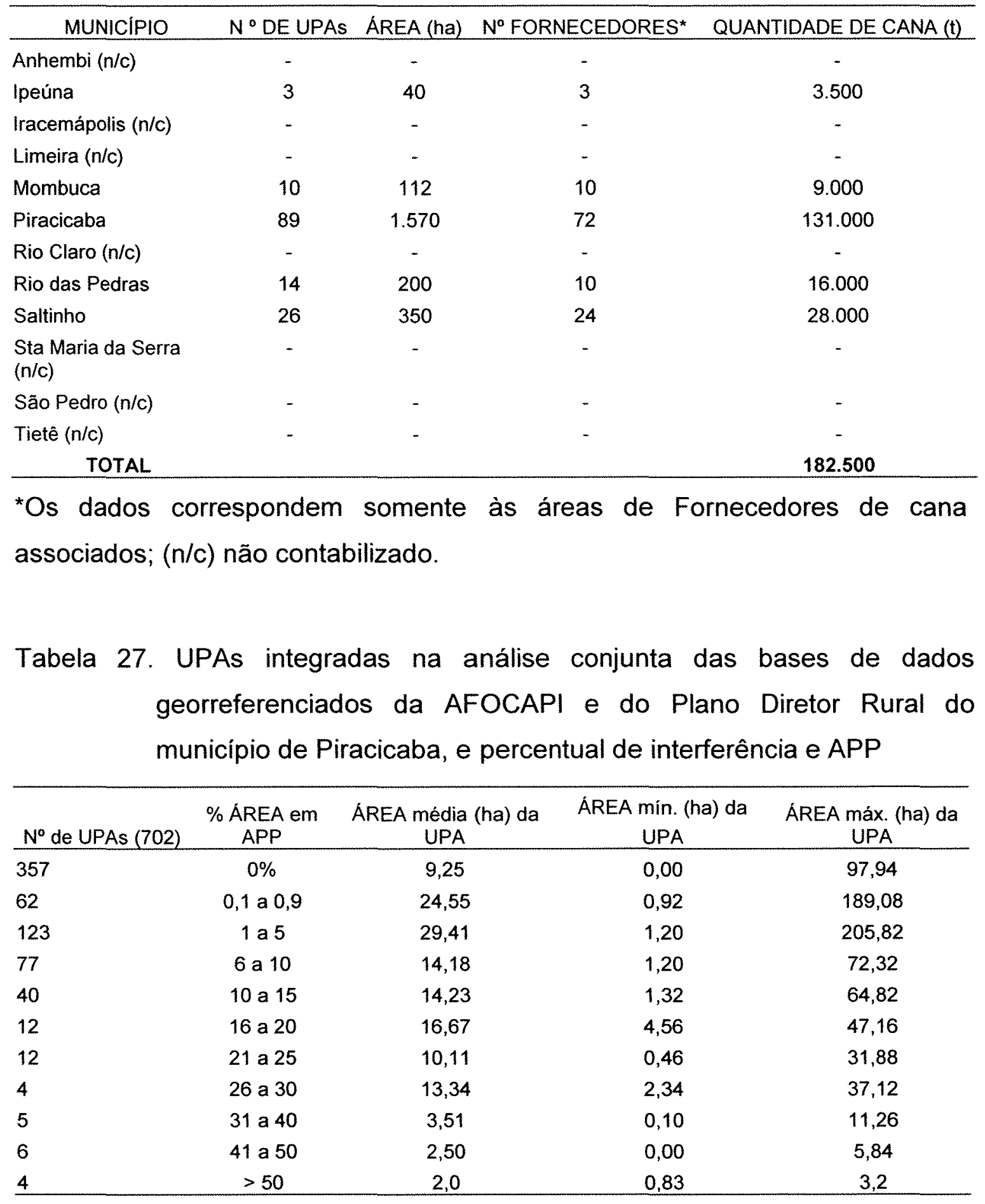


Tabela 28. Resultados pelo número de módulos rurais relacionados com área de cana em APP

\begin{tabular}{lcccc}
\hline $\begin{array}{c}\text { Número de Módulos } \\
\text { Rurais* } / \text { UPA }\end{array}$ & $\begin{array}{c}N^{0} \text { de UPA } \\
\text { levantamento SIG }\end{array}$ & $\%$ UPAs & Área (ha) & $\%$ Área (ha) \\
\hline até 1 & 392 & $44,44 \%$ & 1.892 & $10,80 \%$ \\
de $>1$ até 2 & 164 & $18,59 \%$ & 2.288 & $18,20 \%$ \\
de $>2$ até 3 & 64 & $7,26 \%$ & 1.597 & $13,90 \%$ \\
de $>3$ até 4 & 36 & $4,08 \%$ & 1.250 & $8,90 \%$ \\
de $>4$ até 5 & 16 & $1,81 \%$ & 701 & $6,70 \%$ \\
de $>5$ até 6 & 5 & $0,57 \%$ & 267 & $5,60 \%$ \\
de $>6$ até 7 & 5 & $0,57 \%$ & 319 & $4,70 \%$ \\
de $>7$ até 8 & 4 & $0,45 \%$ & 289 & $3,80 \%$ \\
de $>8$ até 9 & 4 & $0,45 \%$ & 333 & $3,80 \%$ \\
de $>9$ até 10 & 4 & $0,45 \%$ & 377 & $4,10 \%$ \\
de $>10$ até 15 & 4 & $0,45 \%$ & 488 & $8,60 \%$ \\
de $>15$ até 21 & 4 & $0,45 \%$ & 716,81 & $2,30 \%$ \\
de $>21$ até 61 & 0 & $0,00 \%$ & 0 & $0,00 \%$ \\
de $>61$ até 73 & 0 & $0,00 \%$ & 0 & $8,50 \%$ \\
$\quad$ TOTAIS & 702 & $79,59 \%$ & 10.519 & $100 \%$ \\
\hline
\end{tabular}

Tabela 29. Quadro comparativo dos resultados obtidos entre as UPAs integradas na análise conjunta com os dados gerais da Tabela 23

\begin{tabular}{|c|c|c|c|}
\hline$N^{\circ}$ de Módulos Rurais ${ }^{*}$ por UPA & $\begin{array}{c}N^{\circ} \text { de UPAs } \\
\text { levantamento SIG }\end{array}$ & $\begin{array}{c}\% \text { de inclusão levantamento } \\
\text { SIG }\end{array}$ & $\begin{array}{c}\text { Total de UPAs do } \\
\text { municipio }\end{array}$ \\
\hline até 1 & 392 & 89 & 442 \\
\hline de $>1$ até 2 & 164 & 58 & 282 \\
\hline de $>2$ até 3 & 64 & 50 & 127 \\
\hline de $>3$ até 4 & 36 & 61 & 59 \\
\hline de $>4$ até 5 & 16 & 46 & 35 \\
\hline de $>5$ até 6 & 5 & 21 & 24 \\
\hline de $>6$ até 7 & 5 & 29 & 17 \\
\hline de $>7$ até 8 & 4 & 33 & 12 \\
\hline de $>8$ até 9 & 4 & 40 & 10 \\
\hline de $>9$ até 10 & 4 & 40 & 10 \\
\hline de $>10$ até 15 & 4 & 25 & 16 \\
\hline de $>15$ até 21 & 4 & 133 & 3 \\
\hline de $>21$ até 61 & 0 & 0 & 0 \\
\hline de $>61$ até 73 & 0 & 0 & 3 \\
\hline TOTAIS & 702 & 68 & 1040 \\
\hline
\end{tabular}


Tabela 30. Quantidade de UPAs relacionadas à quantidade em metros quadrados de interferência em APP

\begin{tabular}{|c|c|}
\hline ÁREA em APP (m2) & $N^{\circ}$ de UPAs \\
\hline 0 & 343 \\
\hline 1 até 500 & 53 \\
\hline 501 até 1000 & 15 \\
\hline 1001 até 2000 & 38 \\
\hline 2001 até 3000 & 21 \\
\hline 3001 até 4000 & 21 \\
\hline 4001 até 5000 & 22 \\
\hline 5001 até 6000 & 18 \\
\hline 6001 até 7000 & 20 \\
\hline 7001 até 8000 & 13 \\
\hline 8001 até 9000 & 12 \\
\hline 9001 até 10000 & 13 \\
\hline 10001 até 20000 & 64 \\
\hline 20001 até 30000 & 24 \\
\hline 30000 até 40000 & 8 \\
\hline 40001 até 50000 & 7 \\
\hline 50001 até 60000 & 2 \\
\hline 60001 até 70000 & 3 \\
\hline 70001 até 80000 & 1 \\
\hline 80000 até 90000 & 2 \\
\hline 90001 até 100000 & 1 \\
\hline$>100001$ & 1 \\
\hline TOTAIS & $702^{\star *}$ \\
\hline
\end{tabular}

* Total em ha de cana em APP detectada pelo levantamento; ${ }^{* *}$ número de UPAs que foram integradas na análise conjunta; 359 UPAs têm pelo menos alguma parte de interferência em APP. 
Tabela 31. Quadro geral de resultados

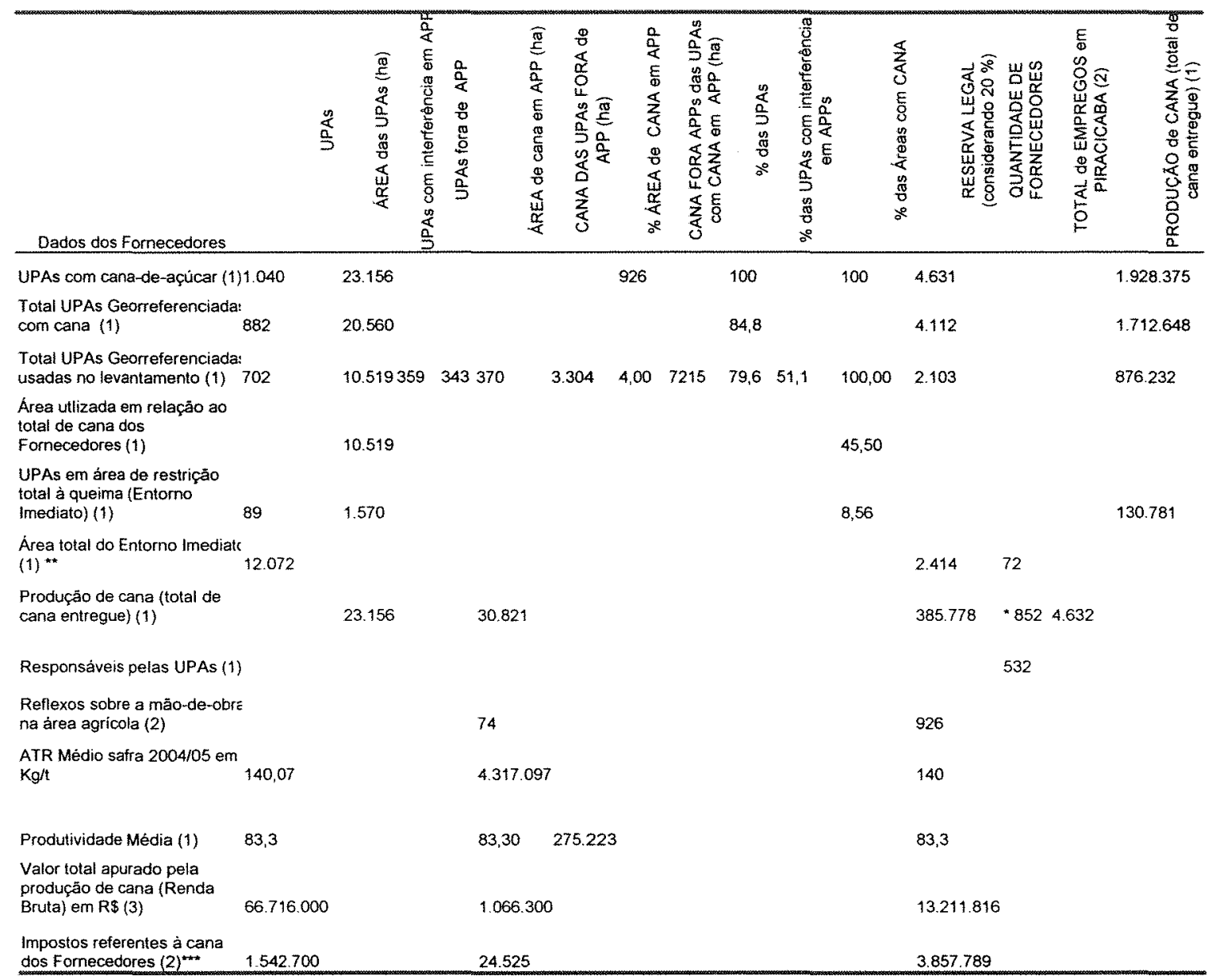

(1) Banco de dados AFOCAPI, (2004 e 2005); (2) (ORPLANA, 2004) (2) *** Impostos gerados: $23 \%$ funrural/tonelada de cana (3) Valor médio do ATR safra 2004/05 foi de R $\$ 0,2445$ (CONSECANA,2005); * agregados + responsáveis; ** Anhumas, Arthemis/Noiva da Colina, Santa Olimpia/Santana, Tanquinho,Tupi/Bartira; Conforme levantamento realizado pela AFOCAPI (2004), em 1000 m da região do entorno.

Deve-se salientar a limitação dos resultados devido à abrangência incompleta da análise.

As áreas de restrição total à queima da palha de cana na região do entorno imediato da sede do município, incluindo-se os principais distritos, somam 1,57 mil ha. Em termos de produção de cana-de-açúcar, essas áreas representam 131 mil toneladas e um valor médio apurado na safra 2004/05 de 4,5 milhões de reais. 
Das 1.040 UPAs de Fornecedores, 702 (67,5\%) puderam ser aproveitadas e possibilitadas de visualização em SIG, representando 10.519 ha $(45,5 \%)$ da área total. Do total de UPAs aproveitadas e possibilitadas de visualização, 359 apresentaram pelo menos alguma área interferindo em APPs, o que representou $4 \%$ (370 ha) da área cultivada. Considerando o total de UPAs dos Fornecedores (23.156 ha), estes $4 \%$ representam 926,2 ha.

Somando-se as áreas com restrição total à queima da palha de cana àquelas que estão utilizando APPs para o cultivo da cana-de-açúcar, revela-se que 2.496 ha deverão deixar de produzir, $\circ$ que corresponde a aproximadamente 208 mil toneladas de cana. 


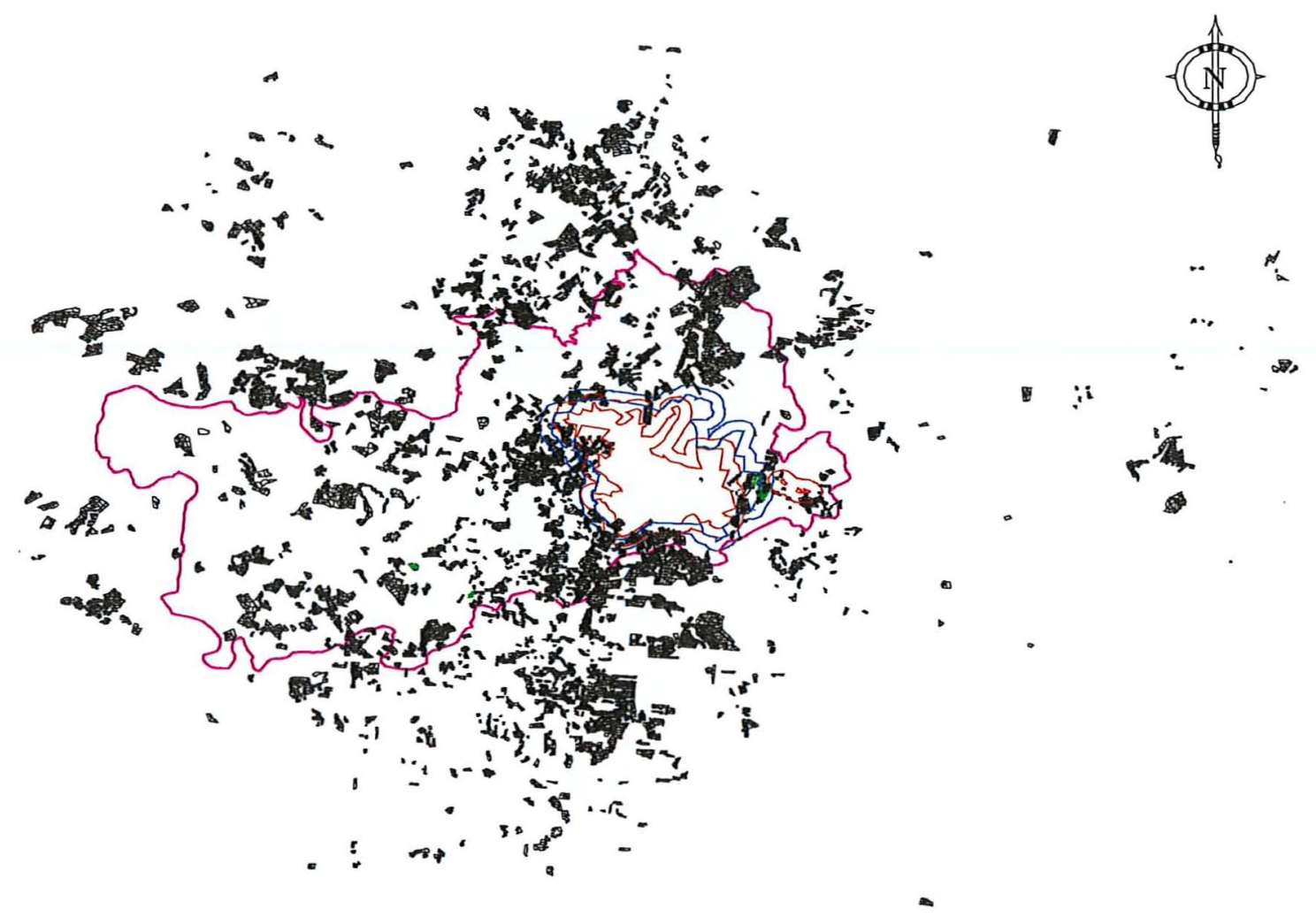

Figura 9 - Distribuição geral das UPAs dos Fornecedores de cana associados da AFOCAPI, na Macro-Região de Piracicaba. 


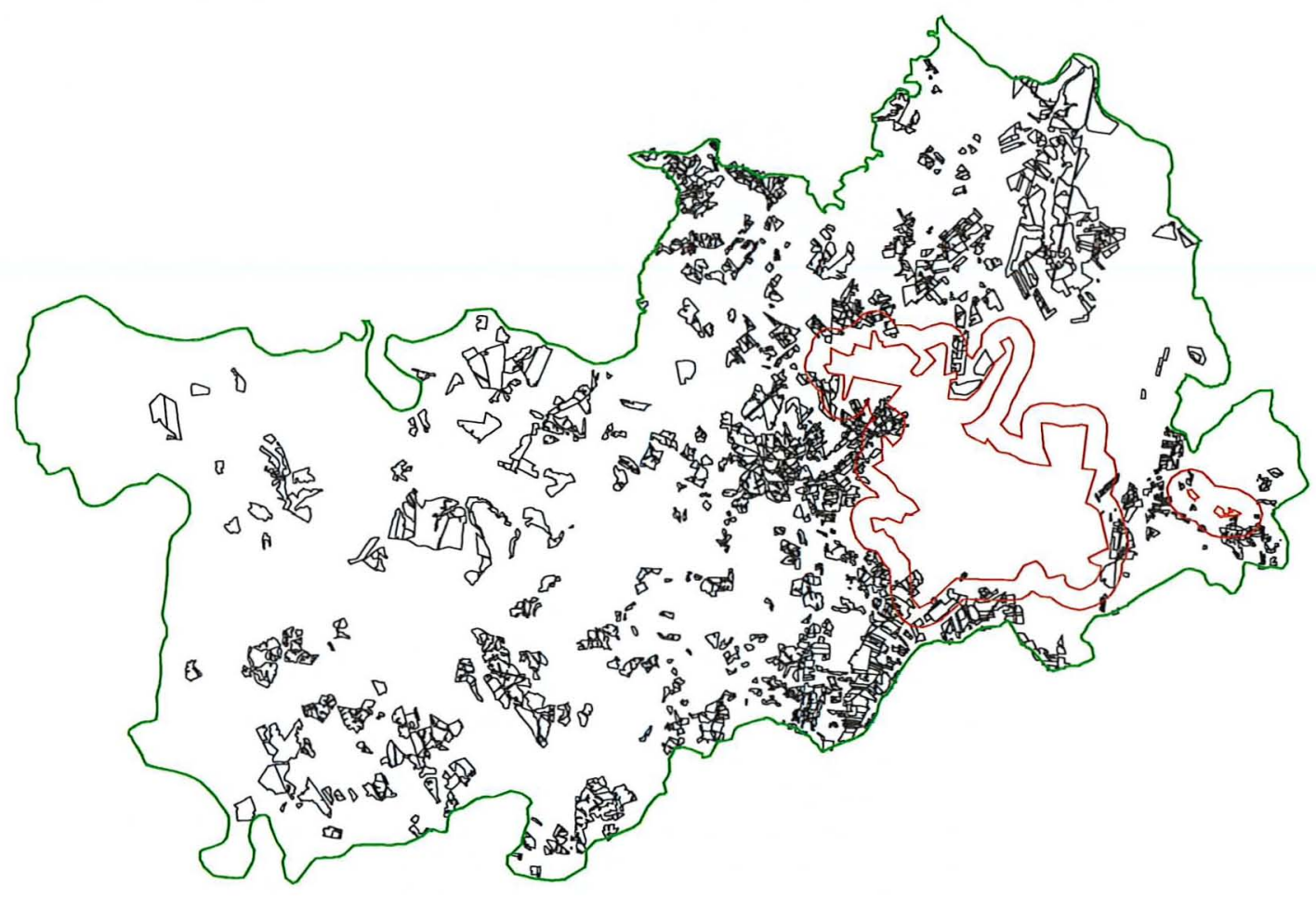

Figura 10 - Área total do município de Piracicaba com a distribuição espacial das UPAs, georreferenciadas. Fonte: AFOCAPI, 2005 


\section{Uso da Terra \& APP}

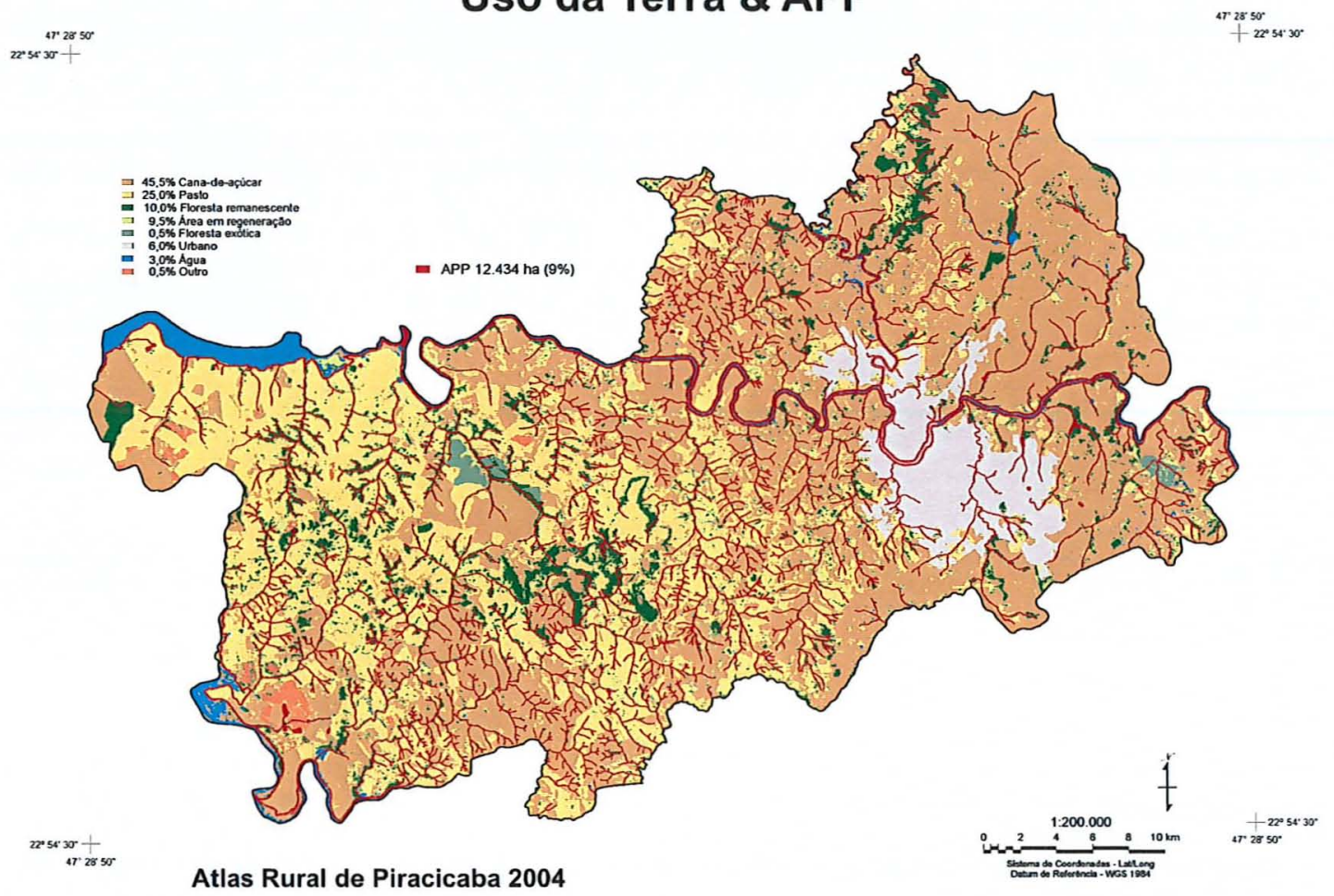

Figura 11 - Sobreposição de temas do Sistema de Georreferenciamento e do Sistema de Informações Geográficas (SIG) TNT mips 6.8 com um buffer gerado de 30,50 e 100 m, conforme exigência da legislação 


\section{DISCUSSÃO}

\subsection{Perfil dos Fornecedores da cana de Piracicaba}

Conforme os dados apresentados, no municipio de Piracicaba $82 \%$ das UPAs dos Fornecedores de cana-de-açúcar são formadas por até dois módulos rurais, ou seja, até 20 ha. Isto caracteriza o perfil de seus Fornecedores como pequenos e médios produtores de cana, em sua maioria com produção nos moldes familiares e representando seu único meio de trabalho e renda. $\mathrm{O}$ produtor é tradicionalmente Fornecedor de cana, sendo esta a principal cultura agrícola há muitas gerações, possuindo máquinas, implementos e a tecnologia necessária, o que o torna preparado para manter e conduzir esta cultura. Além disso, é atendido por entidades de apoio já bem estruturadas, como a Associação dos Fornecedores de Cana de Piracicaba - AFOCAPI, a Cooperativa dos Plantadores de Cana do Estado de São Paulo - COPLACANA, a Cooperativa de Crédito Rural dos Fornecedores de Cana e Agropecuaristas da Região de Piracicaba - COCREFOCAPI e o Sindicato Rural de Piracicaba e Região - SINDIRPI, cujas manutenções são feitas pela sua própria contribuição sobre a produção de cana. Os Fornecedores também conta com sistema de saúde próprio por meio do Hospital dos Fornecedores de Cana - HFC, que atende aos seus familiares e funcionários.

Somando-se a tais características dos Fornecedores, Piracicaba já possui parque agroindustrial voltado para a produção sucroalcooleira, com unidades industriais instaladas no município e na circunvizinhança, como as Usinas do Grupo COSAN - Unidade Costa Pinto (Piracicaba) e Santa Helena 
(Rio das Pedras-SP), Usina São José (Rio das Pedras-SP), Usina Açucareira Furlan (Santa Bárbara D'Oeste-SP), Grupo São Martinho - Usina Iracema (Iracemápolis-SP), Usina Bom Retiro (Capivari-SP) e Usina Zambianco (TietêSP).

Desta forma, a cultura de cana-de-açúcar encontra-se intrinsecamente relacionada com o desenvolvimento sócio-econômico do município de Piracicaba e da região.

A utilização da base de dados do Departamento Técnico Agronômico DTA da AFOCAPI para a avaliação do perfil dos Fornecedores do município provém do fato de que esta é a base mais atualizada sobre os Fornecedores, uma vez que mantém atualização quinzenal de seu banco de dados, no decorrer de cada safra, conforme a entrega da cana feita pelo Fornecedor nas unidades industriais. A apresentação de informações sobre seus associados e respectivas UPAs é capaz de oferecer subsídios para as discussões sobre os efeitos da adequação da produção de cana-de-açúcar dos Fornecedores do município de Piracicaba para o sistema mecanizado da colheita e para a adequação ao Código Florestal. Por outro lado, revela a importância dessa entidade na manutenção e oferecimento de informações sobre esta atividade econômica do municipio, na falta de dados oficiais oferecidos pelo Estado e União.

Relacionando-se as áreas das UPAs utilizadas para o cultivo de canade-açúcar e a quantidade de cana entregue de cada unidade, é possivel ter noção da área ocupada pela cana-de-açúcar em cada UPA, representando bem suas características de produção.

\subsection{A restrição à Queima da palha de cana A Região do Entorno do município}

Piracicaba é uma região tradicionalmente produtora de cana-de-açúcar, onde aproximadamente metade da área cultivada é ocupada com a cultura que 
emprega a maior parte da mão-de-obra rural (Sparovek \& Lepsch, 1995; ORPLANA, 1996).

As colhedoras apresentam dificuldades para operar em área com declividade superior a 12\% (Barbosa, 1997; Furlani Neto, 1997; Sparovek et al., 1996; Silva, 1997).

O município de Piracicaba tem restrições à colheita mecanizada conforme afirma Sparovek et al. (1997), uma vez que parte significativa do cultivo de cana se localiza em solos inaptos para a mecanização da colheita sem queima prévia. Portanto, há dificuldades de ajustes no que se refere ao uso e ocupação do solo no município de Piracicaba.

Desde aquela data, esta situação provavelmente não se alterou significativamente $\mathrm{e}$ as áreas com restrição à colheita mecanizada em Piracicaba continuam envolvendo terras com caracteristicas de relevo de alta declividade. Além disso, outros fatores são limitantes como a alta suscetibilidade à erosão e pedregosidade, condições predominantes nas áreas dos pequenos e médios produtores. Sendo assim, é importante avaliar sistemas de produção alternativos para cana-de-açúcar em áreas inaptas à colheita mecanizada, considerando aspectos ecológicos, agronômicos e sócioeconômicos.

Assim, no atual estádio tecnológico, os pequenos produtores que são os maiores responsáveis pela produção de matéria-prima e ocupam terrenos inclinados, terão capacidade limitada para realizar a colheita mecanizada e continuar sobrevivendo da cana-de-açúcar (Sparovek et al., 1997).

Em relação à região do entorno imediato de 1.000 metros das áreas urbanizadas, existem UPAs produzindo cana-de-açúcar e que ao longo do tempo deverão mudar de atividade agrícola pelas implicações de ordem legal e sócio-econômicas. Tais implicações vão desde a queima de cana ilegal, que ocorre com certa freqüência antes mesmo das unidades industriais iniciarem a moagem, as canas tecnologicamente inaptas à industrialização, até incêndios sem causa determinada. Portanto, são áreas vulneráveis e sujeitas às 
penalizações legais e que também podem significar prejuízos financeiros e morais aos seus proprietários ou responsáveis pela produção.

Bernardes et al. (1998) afirma haver necessidade de mudanças nos sistemas de produção agrícola da região. Uma das formas de manter a economia agrícola regional e do município de Piracicaba é o planejamento das atividades envolvendo a diversificação de atividades e verticalização da produção. Porém, há insuficiência de informações sobre sistemas de produção compativeis com as áreas inaptas à produção de cana-de-açúcar sem queima.

De acordo com Farhat ${ }^{9}$, a colheita mecanizada da cana-de-açúcar deverá ser intensificada em função de vários fatores, tais como: a necessidade de diminuir o custo de produção e aumentar a competitividade no mercado internacional; a extinção da queima da palha de cana para efeito de colheita; o forte apelo ambiental pela co-geração de energia através da biomassa; a escassez de mão-de-obra para o corte; a necessidade de avaliar melhor as vantagens e desvantagens de cada sub-sistema de colheita, respeitando-se as características de cada região, relevo, disponibilidade de mão-de-obra, perfil dos produtores, investimento e financiamentos necessários; os aprimoramentos das colhedoras sob os aspectos de adequação e otimização da colheita, diminuindo as perdas provocadas por injúrias mecânicas por pisoteio nas fileiras de cana, diminuição da compactação do solo, fatores que implicam na longevidade de soqueira e aumento no custo de produção. Estes fatores compõem desafios para os integrantes da cadeia produtiva e responsabilizam os produtores, governos e sociedade por uma produção em bases sustentáveis, que contemple a produção de cana-de-açúcar, o ambiente e a manutenção do emprego e renda. Nas regiōes onde predominam os pequenos e médios produtores, as adequações com relação ao uso e ocupação do solo,

9 FARHAT, M. Sistemas de colheita de cana queimada. (Saccharum spp.). Piracicaba, 2002. 59p. Monografia (Pós-Graduação) - Escola Superior de Agricultura "Luiz de Queiroz", Universidade de São Paulo 
relevo com baixa aptidão à colheita mecanizada deverão resultar em um balanço desfavorável.

$\mathrm{Na}$ agricultura moderna e de alta tecnologia algumas práticas rudimentares ainda são utilizadas como método de manejo em algumas culturas. Não somente fatores econômicos influem nas tomadas de decisões, mas também fatores relacionados às regiões geográficas, ao relevo, às questões sociais e à disponibilidade de tecnologia para a mecanização na prática da agricultura em regiões mais declivosas.

A cultura da cana-de-açúcar favorece a utilização de tecnologia avançada, podendo em certas regiões ser totalmente mecanizada, com eficiência e alta rentabilidade com relação à produção de açúcar. Regiões como as de Ribeirão Preto no Estado de São Paulo oferecem naturalmente condições para que a tecnologia seja aplicada em quase sua totalidade, o que torna possivel mecanizar totalmente as lavouras de cana-de-açúcar. No entanto, esta não é a realidade de outras regiões, também produtoras de cana-de-açúcar, como a Macro Região de Piracicaba.

No município de Piracicaba, pela condição de relevo, somente 30\%, aproximadamente, das áreas ocupadas com a cultura da cana-de-açúcar, oferecem possibilidade de colheita mecanizada enquanto o restante, $70 \%$, possui alguma restrição (Sparovek et. al., 1997). Esta é uma situação onde a evolução da mecanização da lavoura canavieira torna-se mais lenta, portanto se utiliza maior quantidade de mão-de-obra, principalmente para o corte de cana.

É nesse momento, que a queima da palha da cana-de-açúcar para efeito de colheita passa a ser utilizada. É uma forma de manejo eficiente para a diminuição da quantidade de palha como método facilitador para o trabalho dos profissionais do corte de cana.

$\mathrm{Na}$ mesma época em que o setor sucroalcooleiro passava pela desregulamentação e os Fornecedores de cana suportavam preços baixos da tonelada de cana, a legislação de cunho ambiental, criava mais restrições e 
cada vez maiores para a atividade canavieira. Esta legislação exige algumas adequações no sistema de produção da cana-de-açúcar e restringe, gradativamente, a queima da palha como método de despalha facilitador do corte manual. Com a eliminação da queima da palha da cana a colheita deve ser feita em cana crua, podendo ser utilizado corte manual ou mecanizado. A eliminação da queima poderá tornar algumas UPAs improdutivas pela impossibilidade da adequação ao sistema mecanizado, ou pela inviabilidade econômica do corte manual de cana crua.

\subsection{Fornecedores a cana-de-açúcar e o Código Florestal}

Segundo a Constituição Federal (1988), Capítulo VI - Do Meio Ambiente no Artigo 225, "Todos têm direito ao meio ambiente ecologicamente equilibrado, bem de uso comum do povo e essencial à sadia qualidade de vida, impondo-se ao poder público e à coletividade o dever de defendê-lo e preservá-lo para as presentes e futuras gerações"; apresenta no seu $\S 1^{\circ}$ as obrigações ao poder público para assegurar a efetividade desse direito, textualmente "incumbe ao poder público": na alínea "I - preservar e restaurar os processos ecológicos essenciais e prover o manejo ecológico das espécies e ecossistemas; e alínea II - preservar a diversidade e a integridade do patrimônio genético do País e fiscalizar as entidades dedicadas à pesquisa e manipulação de material genético." Então a Constituição Federal confere ao poder público obrigações, entende-se assim, de oferecer financiamento para a recomposição das áreas de APPs e Reserva Legal, ou até indenização, conforme comenta Moraes (2000).

No caso da recomposição das APPs e Reserva Legal, o produtor perderá área de produção, seja para condução de lavouras já estabelecidas ou não, sendo elas de culturas perenes, semi-perenes ou anuais. Porém, para o caso das APPs, é certo que é uma necessidade e sob o ponto de vista de 
preservação de fato, é relevante quando se trata de protegermos os mananciais contra o assoreamento, enchentes e erosões etc.

Há para tanto, argumentação jurídica inconteste sobre as APPs, baseando-se numa citação de Machado (2002) sobre a análise feita por Osny Duarte Pereira sobre o antigo Código Florestal de 1934, que previa as florestas protetoras, correspondendo às APPs do Código atual, que discorria como:

"(...)Evidentemente necessárias e sua consenação não é apenas por interesse público, mas por interesse direto e imediato do próprio dono. Assim como ninguém escava o terreno dos alicerces de sua casa, porque poderá comprometer a segurança das nascentes, das margens dos rios, das encostas das montanhas, ao longo das estradas, porque poderá vir a ficar sem água, sujeito a inundações, sem vias de comunicação, pelas barreiras e outros males conhecidamente resultantes de sua insensatez. As árvores nesses lugares estão para as respectivas terras como o vestuário está para o corpo humano. Proibindo a devastação, o Estado nada mais faz do que auxiliar o próprio particular a bem administrar os seus bens individuais, abrindo-Ihe os olhos contra os danos que poderia inadvertidamente cometer contra si mesmo (...)" (Machado, 2002).

Assim sendo, deixa sem qualquer argumento posição contrária sobre a qualificação e natureza jurídica de tais áreas segundo Moraes (2000), ou seja, as atuais APPs.

Moraes (2000) discorre que as APPs possuem finalidade especifica. Está afetada à conservação de terrenos sujeitos à erosão, desmoronamentos, assoreamento de cursos e reservatórios d'água etc., ou seja, de qualquer maneira o proprietário necessitaria criar essa proteção natural para manter sem dano seu patrimônio e o das áreas vizinhas, que poderiam sofrer os efeitos da má conservação do terreno, o que causaria o dever de indenizar os prejuizos provocados aos proprietários vizinhos, afetados pela omissão de cuidados à área. A argumentação de Moraes (2000) é clara, objetiva e explícita sobre a necessidade de recomposição, caso não exista a área de APPs, especificadas pelo Código Florestal, ou então da manutenção caso a APP já exista. 
Para o caso da Reserva Legal, ainda segundo Moraes (2000), há uma argumentação de natureza jurídica um pouco mais complexa, porém há coerência quando questiona sobre qual a finalidade específica da reserva legal dentro de uma propriedade, sendo que a APP já está vinculada à proteção dos mananciais, flora e fauna, além de precaver qualquer acidente e incidente com os recursos naturais in loco e regionalmente, então não há finalidade da $\mathrm{RL}$ dentro de uma propriedade.

Coletivamente, a $\mathrm{RL}$ pode significar benefício com relação à qualidade ambiental, para toda a região, mas ao proprietário é prejuízo em termos econômicos, em benefício de toda a nação, sendo assim impossível de ser individualizado. Tratando-se de uma propriedade, individualmente, somente há um prejudicado e que deve arcar com o ônus, o proprietário. Portanto, por determinação legal prejudicial ao proprietário, a RL beneficia a toda a nação e se todos se beneficiam, todos deveriam dividir também o ônus, cabendo ao Estado equacionar tal situação.

Pode, a RL, também prejudicar a utilização de áreas destinadas à produção nas pequenas e médias UPAs.

Uma mudança abrupta na cultura de cana-de-açúcar deste município, seria de muito risco à sobrevivência dos produtores e seus familiares, devendo quaisquer que sejam elas, serem calcadas em estudos de viabilidade econômica, além de muita responsabilidade social em conduzi-las.

Com relação à obrigatoriedade da $R L$, os pequenos e médios Fornecedores de Piracicaba estariam deixando de produzir cana-de-açúcar em uma área considerável, porém impossibilitada de ser apurada no levantamento. Muitas UPAs estarão sujeitas à completa estagnação da produção em função da diminuição da área produtiva, podendo assim inviabilizar totalmente o uso da UPA para fins de produção agricola. Considerando que a Lei prevê os $20 \%$ de RL e que o Fornecedor de Piracicaba maximiza a ocupação da sua UPA em cana-de-açúcar, pode-se inferir que ao ocupar a totalidade da UPA, 20\% dessa estaria comprometida com a RL. 
Cumpra-se então, o Estado, conforme a Constituição Federal (1988), no seu art.37, $\S 6^{\circ}$ a sua responsabilidade objetiva, ao causar danos ao particular, neste caso especifico para a averbação, florestamento e/ou reflorestamento da $\mathrm{RL}$ atingindo diretamente o direito ao uso daquele espaço utilizado.

Ainda segundo Moraes (2000), cabe ao Estado a obrigação de indenizar os proprietários cujos imóveis venham a ser afetados, em sua potencialidade econômica, pelas limitações impostas pela Administração Pública.

Com relação a Reserva Legal o levantamento em SIG não possibilitou apurar a quantidade de áreas em ha pelo fato do percentual exigido pelo Código Florestal ser de $20 \%$ da área total de cada UPA e que estejam em conformidade às suas matrículas registradas em Cartório de Imóveis. No entanto, conforme a base de dados da AFOCAPI (2005), a maior parte dos fundos agrícolas medidos possui a sua totalidade em cana-de-açúcar. Dessa forma, pode-se inferir que a implantação da RL nas UPAs dos Fornecedores, poderá significar uma diminuição de aproximadamente 4,7 mil ha cultivados e 386 mil toneladas de cana. Sendo assim, mesmo apontando-se números aproximados da quantidade de cana-de-açúcar que deverá ser extinta com a implantação da RL, esta observação pode refletir impacto considerável, não deixando de lado, porém, a necessidade da realização de levantamento preciso para contabilizar esse número. Embora para efeito de cálculo o levantamento não pôde considerar a RL, a área de cana-de-açúcar deverá ser convertida e refletir em uma diminuição de produção e prejuizos consideráveis.

O restabelecimento ambiental pleno do municipio requer a realização de

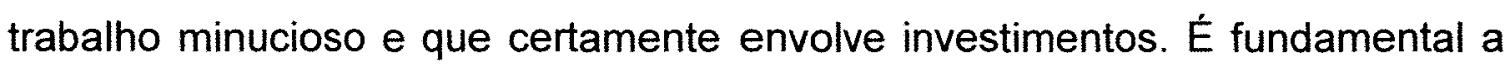
realização de diagnóstico do uso atual da terra com mapeamento que contemple um memorial descritivo, com os dados relacionados às particularidades de cada UPA, os detalhes sobre as remanescentes florestais, seus usos irregulares e as áreas a serem restauradas. 
Após o diagnóstico é de fundamental importância a elaboração de um programa de conservação, manejo e restauração ou recomposição das APPs. Além disso, é necessário fazer levantamento florístico daqueles remanescentes naturais, produzindo um banco de espécies que ocorrem naquela região, orientando a escolha de espécies a serem utilizadas na restauração, e também promover e fomentar a instalação de viveiros para produção de mudas dessas espécies, facilitando a obtenção de mudas pelos interessados. No entanto, deve-se levar em consideração que o custo de um projeto desta natureza é determinante e há necessidade de se trabalhar muito bem todos os elementos envolvidos no sistema para que haja continuidade dos programas ambientais.

Atualmente o município de Piracicaba não dispõe de um instrumento que é básico e importante para a implantação de um programa de ajustamento ambiental de maior amplitude e que são viveiros para a produção de mudas de nativas. Os que existem não correspondem satisfatoriamente às exigências do mercado.

\subsection{Sugestões para a diversificação de culturas}

A diversificação de culturas deverá ser fomentada. Porém, as mudanças não são possiveis de serem implementadas abruptamente em função das questões que são inerentes a tais mudanças, tais como: o aprimoramento que deve ser proposto pela Pesquisa e Desenvolvimento - P\&D, com estudos de viabilidade econômica social e ambiental; aporte financeiro por meio de financiamentos, investimentos em assistência técnica; quais culturas são viáveis para preencher as áreas com baixa aptidão para a cana-de-açúcar e que se igualem em temos de rentabilidade. Neste sentido, sugere-se que para os estudos de viabilidade econômica, social e ambiental, devem ser levados em consideração o desenvolvimento de um Pólo Econômico Florestal, a utilização do SAF-CANA e a utilização de plantas oleaginosas, principalmente a soja. 


\subsection{Outras Considerações}

Devido a aspectos políticos, legislativos e tecnológicos, a adequação das áreas utilizadas com a lavoura de cana-de-açúcar do município de Piracicaba tem implicações em significativas transformações no sistema de produção canavieiro. As principais mudanças têm sido: a obrigatoriedade da adequação das áreas agrícolas à Legislação Ambiental, como a recomposição de áreas degradadas e/ou Áreas de Preservação Permanente - APPs, averbação e recomposição da Reserva Legal; b) a colheita de cana crua, sobretudo a mecanizada, pois a prática da queimada prévia à colheita está sendo gradativamente eliminada; c) a questão social, cuja solução é a manutenção do trabalho. Tais implicações têm repercutido nas demais modificações do sistema, com apelo ambiental e econômico.

A viabilidade para implantação do novo sistema depende de vários fatores que, vão desde um levantamento histórico da agricultura no município, relacionando-se a colonização, as áreas agrícolas que se estabeleceram, a imigração, a economia desenvolvida nos séculos IX e XX, a cana-de-açúcar com mais de cem anos de fortalecimento da economia e a era da moderna tecnologia do setor sucroalcooleiro que, a partir de Piracicaba se estabeleceu em praticamente todo o Brasil. Além disso, é necessário realizar levantamento específico de cada UPA, com detalhes das áreas de produção de cana, escala de produção, diversificação de culturas, APPs e Reserva Legal - RL e quanto da área da UPA significará para a recomposição, quais os reflexos sociais e econômicos e se é possível continuar produzindo cana-de-açúcar nas áreas em que a cultura já está estabelecida. Igualmente importante é conhecer quais são as políticas governamentais direcionadas para o pleno estabelecimento dessas áreas de proteção.

Para tanto, mensurar por meio de levantamento mais completo e com maior riqueza de detalhes é uma necessidade para um plano diretor sustentável, o que sugere a utilização de instrumentação computacional na 
aplicação de modelos de simulação de culturas como uma importante ferramenta para a realização de planejamentos e análises e avaliações ambientais racionais e adequadas.

Piracicaba está inserida em uma das principais bacias hidrográficas do Estado de São Paulo ${ }^{10}$ e requer grande cuidado para com o ambiente, mas também grande investimento, incentivos de forma a tornar um negócio atrativo ao meio rural e alguns anos, para que o ideal, no que se refere a recomposição das APPs, seja estabelecido. Tão somente a recomposição das APPs não contempla toda determinação legal, deve-se também considerar a RL.

Além das exigências do Código Florestal, há também a legislação de queima de cana, determinando o fim das queimadas, cujo cumprimento implica em alguns sacrifícios por parte dos Fornecedores, dos Trabalhadores Rurais e das Unidades Industriais de açúcar e álcool, cujo reflexo econômico é notado em curto espaço de tempo. A maior implicação é de ordem técnica, sendo a declividade acentuada das terras, na maior parte do município, acima de $12 \%$ (Sparovek et al., 1997).

Outra implicação, e não de menor importância, é a falta de capital por parte do produtor para investimento na mecanização de áreas apropriadas para a colheita mecânica, economicamente viável em áreas contínuas acima de 500 ha (Gonçalves \& Souza, 1998a).

Portanto, partindo da premissa que o meio rural deve ser cumpridor da lei, a análise do problema sugere estudos mais aprimorados e com maior nível de detalhes abordando os seguintes aspectos: reais benefícios do Código Florestal para o município de Piracicaba; perspectiva da sociedade sobre o impacto negativo da agricultura sobre o ambiente; impacto da transformação imediata das áreas com cana-de-açúcar, que por lei deverão ser transformadas em APPs ou RLs, sobre a captação de $\mathrm{CO}_{2}$; os reflexos sobre os produtores de cana e sobre a sociedade local, com a aplicação da legislação; as ações locais

10 Bacia Hidrográfica dos Rios Capivari, Piracicaba e Jaguari 
para diminuírem o impacto da legislação ambiental; proposta SAF Cana em áreas com declividade acima de $12 \%$ e seus beneficios para os ambientes de produção; distância entre as teorias e as práticas com a adoção integral da Legislação ambiental; os efeitos diretos na produção e a relação entre o problema causado pela diminuição da produção e a renda do produtor no município de Piracicaba; incentivar e induzir aqueles que devem restabelecer áreas de APPs oferecendo alternativas para que os ajustes legais sejam feitos; o produtor rural deve ser considerado um "produtor mais amplo" e passará a ser também um "produtor de água" com o aumento das áreas de conservação, APPs e RIs. Desta forma, ele estará contribuindo e se responsabilizando pela preservação e manutenção destes mananciais. Para tanto, deve ser compensado, seja na forma de diminuição de impostos ou pagamento direto, a não cobrança pelo uso da água e fornecimento de assistência técnica e mudas, financiamentos de baixo custo ou a fundo perdido para a implantação dos projetos. Assim, agricultor e Fornecedor de cana será transformado num agente econômico que preserva os recursos naturais.

Devem-se organizar políticas públicas que ofereçam subsídios às tomadas de decisão de forma a permitir a recomposição do ambiente pela aplicação integral da legislação nas áreas determinadas e compatibilização dos prejuízos econômicos causados ao Fornecedor. Dessa forma, permitirá aos Fornecedores de cana que continuem na atividade agricola, porém, como produtores diferenciados.

Portanto, sem a contraposição de incentivos pode ocorrer a inviabilização da sustentabilidade da produção canavieira ou de parte dela. 


\section{CONCLUSÕES}

- O município de Piracicaba possui significativa área utilizada na produção de cana-de-açúcar que deverá ser ajustada em relação à legislação ambiental vigente.

- Pelas características e importância social e econômica da canavicultura para o País há necessidade de empenho na atualização das informações e oficialização dos dados.

- Ao longo do tempo, as UPAs localizadas na região do entorno imediato de $1.000 \mathrm{~m}$, onde a queima da palha da cana é totalmente proibida, deverão mudar de atividade agrícola pelas implicações de ordem legal, social e econômica.

- Há um expressivo número de pequenos e médios Fornecedores de cana-de-açúcar no município de Piracicaba e parte deles possui Unidades de Produção Agrícolas - UPAs interferindo em Áreas de Preservação Permanente - APPs. Este levantamento serve como indicador de problemas relacionados à necessidade de ajustes ambientais em áreas com cana-de-açúcar interferindo em APPs.

- O levantamento não possibilitou apurar a quantidade de ha da Reserva Legal, porém ocorrerá diminuição da área de cana dos Fornecedores. Há necessidade de um levantamento preciso para contabilizar esse número.

- A legislação ambiental brasileira é complexa, rigida e contempla de forma primaz o ambiente e todas as formas de preservação, porém é questionável quando deixa de considerar os problemas ocasionados à 
sobrevivência das atuais gerações de agricultores, sobretudo dos pequenos e médios.

- Sob o aspecto de políticas públicas o Estado deve levar em consideração que parte dos produtores e da produção serão penalizados em benefício do bem comum, por isso deve estar preparado para dar aporte aos produtores continuarem suas atividades agricolas naquelas áreas permitidas, e fomentar as mudanças da mesma forma que obriga cumprirem a legislação.

- Subsidiar a adequação às exigências do ambiente em UPAs destinadas ao cultivo da cana-de-açúcar requer diagnóstico criterioso para que a aplicação plena da legislação ambiental seja revertida em benefícios de grande monta para a sociedade, sem que parte dessa população, que são os Fornecedores, seja marginalizada do sistema produtivo pela aplicação da lei.

- A total aplicação da legislação sem a contraposição de incentivos pode inviabilizar a sustentabilidade da produção canavieira no município de Piracicaba. 


\section{REFERÊNCIAS BIBLIOGRÁFICAS}

ASSOCIAÇÃO DOS FORNECEDORES DE CANA DE PIRACICABA. Relatório interno (software). Piracicaba: AFOCAPI, 2003.

ASSOCIAÇÃO DOS FORNECEDORES DE CANA DE PIRACICABA. Relatório interno (software). Piracicaba: AFOCAPI, 2004.

ASSOCIAÇÃO DOS FORNECEDORES DE CANA DE PIRACICABA. Relatório interno (software). Piracicaba: AFOCAPI, 2005.

BALASTREIRE, L.A. Máquinas agrícolas. São Paulo: Manole, 1987. 307p.

BALSADI, O.V.; CARON, D.; SILVA, J.G.; BIRAL, M.A.M. A demanda regional da força de trabalho agrícola no Estado de São Paulo e sua sazonalidade. Informações Econômicas, v.25, n.6, p.19-30, 1995.

BANCO DO BRASIL. Sucroalcooleiro. BB Panorama Setorial, v.9, n.81, p.39$42,2000$.

BARBOSA, V. Cultivo de soqueira, adubação e reforma de canaviais sob sistema de cana crua. In: SEMANA DE CANA-DE-AÇÚCAR DE PIRACICABA, 2., Piracicaba, 1998. Anais. Piracicaba: STAB, 1997. p.5254. 
BERNARDES, M.S.; SPAROVEK, G. Sistemas de produção para áreas com restrições à colheita mecanizada de cana-de-açúcar. Piracicaba: ESALQ, Departamento de Agricultura; Ciência do Solo, 1998. 27 p. (Projeto de Pesquisa).

BERNARDES, M.S.; CASTRO, P.R.C.; MARTINS, A.N. Formação da copa e resistência de árvores ao vento: modelo de seringueira. Piracicaba: FEALQ, 1996. 88 p.

BERNARDES, M.S.; SPAROVEK, G.; ROSSETTO, R.; FARHAT, M.; VICCINO, J.R.; STAPE, J.L.; HAMMERSCHLAG, N. Sistemas de produção para áreas com restrições à colheita mecanizada de cana-de-açúcar. In: SEMANA DE CANA-DE-AÇÚCAR DE PIRACICABA, 3., Piracicaba. 1998. Anais. Piracicaba: STAB. 1998. p.35-37.

BILAC, M.B.B.; TERCI, E.T. Piracicaba de centro policultor a centro canavieiro (1930-1950). Piracicaba: UNIMEP, 2001. 109 p.

BOVI, J.E.; HAMMERSCHLAG, N.; BASSO, E.; SIMÕES, F.L. Plano de microbacia hidrográfica Ribeirão dos Marins. Piracicaba: CATI/SEMA. 2001. 1v. (Relatório da Equipe de trabalho da Casa da Agricultura de Piracicaba; CATI; Secretaria Estadual de Agricultura e Abastecimento; Secretaria de Agricultura e Abastecimento do Município de Piracicaba).

BURESH, R. Agroforestry research for integrated land use: nutrient management research in agroforestry. Nairobi: ICRAF, 1995. 28p.

CÂMARA PAULISTA DO SETOR SUCROALCOOLEIRO. Resultados de safra http://www.orplana.com.br/resultsafra4.htm>. (01 fev.2004).

CARDOSO, E. A motomecanização dos canaviais paulistas. Brasil Açucareiro, v.39, n.2, p.67-69, 1952. 
CARVALHO FILHO, S.M. Colheita mecanizada: desempenho operacional e econômico em cana sem queima. Piracicaba, 2000. 137 p. Dissertação (Mestrado) - Escola Superior de Agricultura "Luiz de Queiroz", Universidade de São Paulo.

CONSELHO DOS PRODUTORES DE CANA-DE-AÇÚCAR, AÇÚCAR E ÁLCOOL DE SÃO PAULO. Manual de instruções. 4.ed. Piracicaba, 2003. $116 \mathrm{p}$.

COOPERATIVA DOS PLANTADORES DE CANA DO ESTADO DE SÃO PAULO. Relatório interno (software). Piracicaba, 2004.

COOPERATIVA DE PRODUTORES DE CANA, AÇÚCAR E ÁlCOOL DO ESTADO DE SÃO PAULO. Proálcool: fundamentos e perspectivas. São Paulo, 1989. 121p.

COORDENADORIA DE ASSISTENNCIA TÉCNICA INTEGRAL. LUPA. $<$ http://www.cati.sp.gov.br/novacati/index.php>. (19 dez.2004).

DANIELS, J.; ROACH, B.T. Taxonomy and evolution. In: HEINZ, D.J. (Ed.). Sugarcane improvement through breeding. Amsterdan: Elsevier, 1987. p.7-84.

FACCENDA, O; SOUZA, L.G. Desempenho em co-geração em uma indústria de processamento de cana. Engenharia Rural, v.9, n.1, p-21-32, 1998.

FARHAT, M. Histórico da Cooperativa dos Plantadores de Cana do Estado de São Paulo. Canavieiro Paulista, v.16, n. 88, p.1-16, 2003. 
FARHAT, M. Assistência técnica: uma atribuição das entidades associativas e cooperativas de produtores rurais no agronegócio experiência da COPLACANA e AFOCAPI. In: CONGRESSO BRASILEIRO DE ASSISTÉNCIA TÉCNICA À AGRICULTURA, Piracicaba, 2004. Anais. Piracicaba: FEALQ; AGROESP, 2004. p. 190 - 197.

FERNANDES, A.J. Manual da cana-de-açúcar. Piracicaba: Livroceres, 1984. $158 \mathrm{p}$.

FIGUEIREDO, P.; LANDELL, M.G.A.; CAMPANA, M.P. Instruções agrícolas para as principais culturas econômicas (compact disc). 6.ed. Campinas: IAC, 1995. (IAC. Boletim, 200).

FNP CONSULTORIA \& COMÉRCIO. AGRIANUAL 1997: anuário estatístico da agricultura brasileira. São Paulo, 1997. 168 p.

FUNDAÇÃO SISTEMA ESTADUAL DE ANÁLISE DE DADOS. Boletim de acompanhamento da demanda da força de trabalho agrícola no estado de São Paulo e no Brasil. http://www.seade.gov.sp.br (05 mar. 2005).

FURLANI NETO, V.L. Gerenciamento e sistematização de áreas para colheita mecanizada de cana-crua. In: SEMANA DA CANA-DE-AÇÚCAR DE PIRACICABA, 2., Piracicaba, 1997. Anais. Piracicaba: STAB, 1997. p. 4951.

GODOY, O.P.; TOLEDO, F.F. Cultura da cana-de-açúcar. Piracicaba: ESALQ. 1972. 63 p.

GONÇALVES, D.B. A regularização das queimadas e as mudanças nos canaviais paulistas. Campinas, 2001. 113p Dissertação (Mestrado) Faculdade de Engenharia Agrícola, Universidade Estadual de Campinas. 
GONÇALVES, J.S.; SOUZA, S.A.M. Alternativas econômicas para áreas com restrição à colheita mecanizada da cana-de-açúcar, na região de Piracicaba-SP. In: SEMANA DE CANA-DE-AÇÚCAR DE PIRACICABA, 3., Piracicaba, 1998. Anais. Piracicaba: STAB, 1998a. p.4-8.

GONÇALVES J.S.; SOUZA, S.A.M. Proibição da queima de cana no Estado de São Paulo: simulações dos efeitos na área cultivada e na demanda pela força de trabalho. Informações Econômicas, v.28, n.3, p 21-40, 1998b.

INSTITUTO DE PESQUISAS E ESTUDOS FLORESTAIS. Pólo industrial de base florestal: projeto de pesquisa cooperativa e prestação de serviços de consultoria, Instituto de Pesquisas e Estudos Florestais - IPEF. Piracicaba: ESALQ, 2004. 9 p.

JUNGMAMM, F. O direito da agroindústria açucareira. São Paulo: Editora Revista dos Tribunais, $1971.35 \mathrm{p}$

LEÃO, R.M. Álcool, energia verde. São Paulo: Iqual Editora, 2002. 256p.

LICHTI, F.M.; SANTOS, F.M. História de Santos - Poliantéia Santista. São Vicente: Caudex Ltda, 1986. $1 \mathrm{v}$.

LIMA, W.P. Função hidrológica da mata ciliar. In. SIMPÓSIO SOBRE MATA CILIAR, Campinas, 1989. Anais. Campinas: Fundação Cargill, 1989. p. 25 -41 .

LUCA, E.F. de. Cana crua $x$ queimada (compact disc). In: REUNIÃO AGRÍCOLA - ENCONTROS FERMENTEC, Piracicaba, 2002. Piracicaba: FERMENTEC, 2002. 
MACHADO, P.A.L. Legislação das matas ciliares. In: SIMPÓSIO SOBRE MATA CILIAR, Campinas,1989. Anais. Campinas: Fundação Cargill, 1989. p. 2 -10.

MACHADO, P.A.L. Direito ambiental brasileiro. 10.ed. São Paulo: Malheiros, 1992. $1038 \mathrm{p}$.

MAGALHÃES, A.C.N. Ecofisiologia da cana-de-açúcar: aspectos do metabolismo do carbono na planta. In: CASTRO, P.R.C.; FERREIRA,S.O.; YAMADA, T. (Coord.). Ecofisiologia da produção. Piracicaba: POTAFOS, 1987. p.113-118.

MANFRINATO, W. Protocolo de Quioto: mudanças climáticas, o mercado de carbono e o setor sucroalcooleiro. (compact disc). In: REUNIÃO AGRÍCOLA - ENCONTROS FERMENTEC, Piracicaba, 2002. Piracicaba: FERMENTEC, 2002.

MASCARENHAS, H.A.A.; TANAKA, R.T. Soja e adubos verdes, uma boa opção na renovação do canavial. O Agronômico, v.52, n.1, p.19, 2000.

MASCARENHAS, H.A.A.; TANAKA, R. T.; WUTKE, E.B. A cultura da soja gera nitrogênio assimilável para a produção de milho, arroz, trigo, sorgo e canade-açúcar. STAB. Açúcar, Álcool e Subprodutos, v.21, n.4, p.18-19, 2003.

MATSUOKA, S.; LAVORENTI, N.A.; MENEZES, L.L.; SALIBE, A.C.; GHELLER, A.C.A.; ARIZONO, H. Novas variedades de cana-de-açúcar para a região Oeste do Estado de São Paulo. In: CONGRESSO NACIONAL DA SOCIEDADE DOS TECNICOS ACUCAREIROS E ALCOOLEIROS DO BRASIL 7., Londrina, 1999. Anais. Piracicaba: STAB, 1999, p.34-39. 
MIRANDA, E.E. de; DORADO, A.J.; ASSUNÇÃO, J.V. de. Doenças respiratórias crônicas em quatro municípios paulistas. 2.ed. Campinas: ECOFORÇA, 1995. 139p.

MORAES, L.C.S. O Código Florestal comentado: com as alterações da lei de crimes ambientais, Lei $n^{\circ}$ 9.605/98. 2.ed. São Paulo:Atlas, 2000. 274 p.

MORAES, M.A.F.D. A desregulamentação do setor sucroalcooleiro do Brasil. Piracicaba, 1999. 292 p. Tese (Doutorado). - Escola Superior de Agricultura "Luiz de Queiroz", Universidade de São Paulo.

MORAES, M.A.F.D. A desregulamentação do setor sucroalcooleiro do Brasil. Americana: Caminho Editorial, 2000. 49p.

MOURÃO, J.O.F. Piracicaba 2010: realizando o futuro. Piracicaba: Piracicaba 2010, 2001. $115 \mathrm{p}$.

ORGANIZAÇÃO DE PLANTADORES DE CANA DA REGIÃO CENTRO SUL DO BRASIL. Queima da cana-de-açúcar: informações disponiveis. Piracicaba: ORPLANA, 1996. 19 p. (Boletim técnico).

ORGANIZAÇÃO DE PLANTADORES DE CANA DA REGIÃO CENTRO SUL DO BRASIL. Estatísticas. <http://www.orplana.com.br/estatisticas.asp>. (19 dez.2004).

ORGANIZAÇÃO DE PLANTADORES DE CANA DA REGIÃO CENTRO SUL DO BRASIL. Informativo. <http://www.orplana.com.br/informativo_ ORPLANA.asp> (20 maio2005). 
ORGANIZAÇÃO DE PLANTADORES DE CANA DA REGIÃO CENTRO SUL DO BRASIL. Resultados tecnológicos obtidos pelos Fornecedores de cana-de-açúcar do estado de São Paulo. Piracicaba, 2004. 194p.

PINTO, L.A.R. Colheita de cana-de-açúcar. Brasil Açucareiro, v.89, n.4, p.39$51,1977$.

PINTO, L.F.G. Avaliação do cultivo de cana-de-açúcar em sistemas agroflorestais em Piracicaba. Piracicaba. 2002. 116 p. Tese (Doutorado) Escola Superior de Agricultura Luiz de Queiroz", Universidade de São Paulo.

PINTO, L.F.G.; BERNARDES, M.S.; NOORDWIJK, M.V.; PEREIRA, A.R.; SPAROVEK, G. Avaliação do cultivo de cana-de-açúcar em sistemas agroflorestais na região de Piracicaba, SP. In: CONGRESSO NACIONAL DA SOCIEDADE DOS TÉCNICOS AÇUCAREIROS E ALCOOLEIROS DO BRASIL,8., Pernambuco, 2002. Anais. Piracicaba: STAB, 2002. p. 506-512.

RIPOLI, T.C.C. Considerações sobre colheita mecânica da cana-de-açúcar. Revista de Mecanização Rural, v.1, n.4, p.31-35, 1981.

RIPOLI, T.C.C. Utilização do material remanescente da colheita da cana-deaçúcar (Saccharum spp.) - equacionamento dos balanços energético e econômico. Piracicaba,1991. 150p. Tese (Livre Docência) - Escola Superior de Agricultura "Luiz de Queiroz", Universidade de São Paulo.

RIPOLI, T.C.C.; BALASTREIRE, L.A. Contribuição ao estudo do sistema de colheita mecanizada de cana-de-açúcar. Brasil Açucareiro, v.87, n.4, p.11-17, 1976. 
RIPOLI, T.C.C.; MIALHE, L.G. Custos de colheita da cana-de-açúcar no Estado de São Paulo, 1981/82. Álcool \& Açúcar, v.2, n.2, p.18-26, 1982.

RIPOLI, T.C.C.; PARANHOS, S.B. Colheita. In: PARANHOS, S.B. (Coord). Cana-de-açúcar: cultivo e utilização. Campinas: Fundação Cargill, 1987. v.2, p. 517-597.

RIPOLI, T.C.C.; RIPOLI, M.L.C. Biomassa de cana-de-açúcar: colheita, energia e ambiente. Piracicaba: Barros \& Marques Editoração Eletrônica, 2004. 302 p.

RIPOLI, T.C.C.; MOLINA JR., W.F.; RIPOLI, M.L.C. Energy potential of sugar cane biomass in Brazil. Scientia Agricola, v.57, n.4, p.677-681, 2000.

RIPOLI, T.C.C.; TILLMANN, C.A.C.; MILAN, M. O corte manual na cana verde. Açúcar \& Álcool, n.77, p.28-30, 1995.

ROMANACH, L.M.; CARON, D. Impactos da mecanização da colheita da cana sobre o emprego, a gestão empresarial e o meio ambiente, um estudo de caso (compact disc). In: CONGRESSO BRASILEIRO DE ECONOMIA E SOCIOLOGIA RURAL, 37., Foz do Iguaçu, 1999. Anais. Foz do Iguaçu: SOBER,1999. p.77.

SÃO PAULO. Leis, Decretos, etc. Decreto no 10.547 de 06 de junho de 2000. Diário Oficial do Estado de São Paulo, 06.jun.2000. Seção 1, p. Dispõe sobre dispõe sobre a queima controlada de cana-de-açúcar para o Estado de São Paulo.

SÃO PAULO . Leis, Decretos,etc. Decreto $n^{\circ} 11.241$ de 19 de setembro de 2002. Diário Oficial do Estado de São Paulo, 19.set.2002. Seção 1, p. Dispõe sobre a queima controlada de cana-de-açúcar para o Estado de São Paulo. 
SERODIO, E. Analisando as políticas existentes e traçando perspectivas para o setor sucroalcooleiro. In: INTERNATIONAL BUSINESS COMMUNICATIONS, São Paulo, 1999. Anais. São Paulo: UNICA, 1999. p.14-17.

SILVA, G.M.A. Cana crua $x$ cana queimada: restrições técnicas e implicações sociais e econômicas. In: SEMANA DA CANA-DE-AÇÚCAR DE PIRACICABA, 2., Piracicaba, 1997. Anais. Piracicaba: STAB, 1997. p.5557.

SPAROVEK, G. Plano Diretor Rural - Atlas Rural de Piracicaba 2003. Piracicaba: ESALQ, 2003 (Relatório do Plano Diretor de Desenvolvimento Sustentável do Município de Piracicaba apresentado na $2^{\mathrm{a}}$ Conferência da Cidade em 25/10/2003).

SPAROVEK, G.; LEPSCH, I.F. Diagnóstico de uso e aptidão das terras agrícolas de Piracicaba. In: TAUK-TORNISIETO, S.M.; GOBBI, N.; FORESTI,C.; LIMA, S.T. Análise ambiental: estratégias e ações. São Paulo: Fundação Salim Farah Maluf, 1995. p.273-279.

SPAROVEK, G.; PEREIRA, J.C.; ALLEONI, L.R.F.; ROSSETTO, R. Aptidão das terras de Piracicaba (SP) para o corte mecanizado de cana-de-açúcar. STAB. Açúcar, Álcool e Subprodutos, v.15, n.5,p.6-9, 1997.

SUGUITANI, C. Fenologia da cana-de-açúcar (Saccharum spp.) sob efeito do fósforo. Piracicaba, 2001. 71p. Dissertação (Mestrado) - Escola Superior de Agricultura "Luiz de Queiroz", Universidade de São Paulo.

SZMRECSÁNYI, T. Tecnologia e degradação ambiental::o caso da agroindústria canavieira no estado de São Paulo. Informações Econômicas, v.24, n.10, p.73-78, 1994. 
TORRES, M.C.T.M. Aspectos da evolução da propriedade rural em Piracicaba no tempo do Império. Piracicaba: Academia Piracicabana de Letras, $1975.130 \mathrm{p}$.

UNIÃO DA AGROINDÚSTRIA CANAVIEIRA DE SÃO PAULO. Safras. Informação UNICA, v. 2, n.23, p.4, 1999.

UNIÃO DA AGROINDÚSTRIA CANAVIEIRA DE SÃO PAULO. Aspectos sociais, econômicos e tecnológicos da produção de açúcar e álcool no Estado de São Paulo: 2001/2002. São Paulo, 2002. 28p.

UNIÃO DA AGROINDÚSTRIA CANAVIEIRA DE SÃO PAULO. Memória. $<$ http://www.portalunica.com.br>. (16 out. 2004).

VEIGA FILHO, A.A. Cadeia agroindustrial do açúcar, álcool e subprodutos. São Paulo: Secretaria de Agricultura e Abastecimento do Estado de São Paulo, 1996. 19p.

VEIGA FILHO, A.A. Estudo do processo de mecanização do corte na cana-deaçúcar: o caso do estado de São Paulo, Brasil. RECITEC, v.3, n.1, p.74-99, 1999.

VEIGA FILHO, A.A.; SANTOS, Z.A.P.S. Estimativa de desemprego na colheita de cana decorrente de mecanização. STAB, Açúcar, Álcool e Subprodutos, v.13, n 4, p.19-21, 1995a.

VEIGA FILHO, A.A.; SANTOS, Z.A.P.S. Padrão tecnológico da cana-de-açúcar no Estado de São Paulo: evidências empíricas da evolução na cultura. Informações Econômicas, v.25, n.8, p.15-25, 1995b.

ZANCA, O. The evolution of mechanized sugar cane harvesting in Brazil. International Sugar Journal, v.82, n.973, p. 7-10, 1980. 